Historic, Archive Document

Do not assume content reflects current scientific knowledge, policies, or practices. 



\section{$62 .+3$}

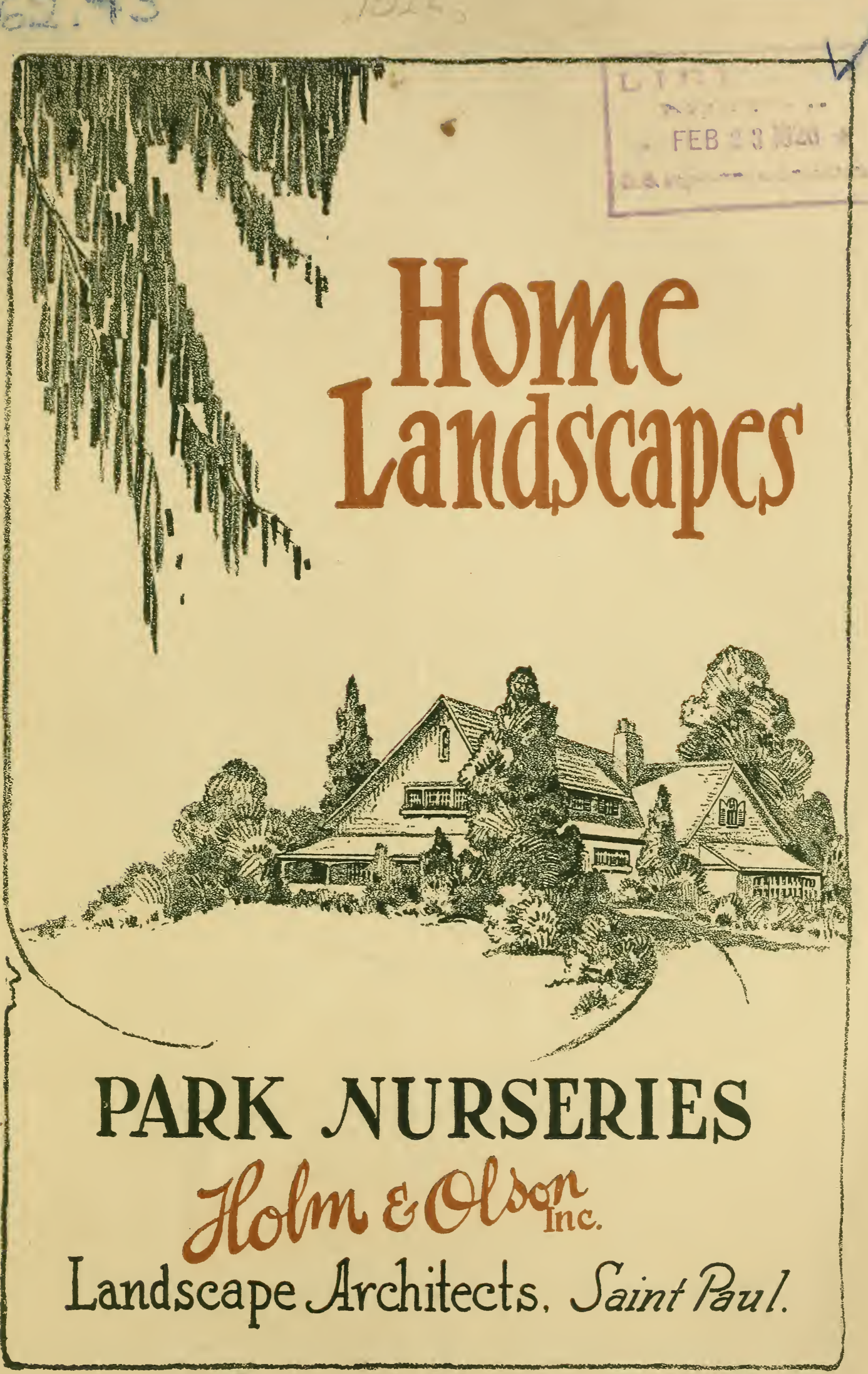




\section{WHEN YOU ORDER}

ADVANCE ORDERS. An early order enables us to give your requirements particularly good attention. Orders placed in advance of the actual shipping season can invariably be handled with greater care and precision than those reaching us in the midst of the planting rush.

CORRESP.ONDENCE. Inquiries as to plants or landscape work are solicited and will receive our most careful and prompt attention.

CREDIT. New customers who desire to open accounts are asked to give the usual bank or commercial references. Accounts are due and payable by the 10th of the month following receipt of statement.

PRICES are always based on stock at our nurseries. Careful packing is done without charge.

SHIPPING INSTRUCTIONS. Please give directions how to ship (whether freight, express or parcel post) and best route where any preference. When not instructed we will use our best judgment. When shipments are receipted for as in good condition by the transportation company, our responsibility ceases. Any claim for damage or delay in transit should be made promptly to the delivering company who alone is responsible.

LIBERAL REPLACEMENT OFFER made because of our confidence in the vitality of our hardy Northern-grown plants. We agree to re-supply $F . O$. B. our nurseries at one-half of the original purchase price, any nursery stock purchased from us at catalogue rates that may fail to grow the first season from causes other than abuse or neglect. This offer applies only to accounts that are promptly paid in full when due. Any labor involved in planting such replace orders is to be charged in full to the customer.

There are good reasons why plants may sometimes fail to grow well after transplanting. Poor soil, dried condition due to transportation delay, careless or improper culture, excessive drought, neglect, insect or disease attacks are some of the causes often to blame. After delivering plants in good order to your home or to the transportation company it is obvious that we have no control whatever over these future conditions. It is not reasonable, therefore, to ask us, nor do we in any way agree, to guarantee the results or the outcome of plantings. Should any plant prove untrue to variety ordered we will replace it without charge or refund the purchase price.

Catalogue index, listing plants under both common and botanical names, will be found inside the back cover. 


\section{Make the Most of Your Grounds Our Practical Landscape Service Can Help You}

Think of the daily pleasure and healthful enjoyment you can give to all the family in making the home vard attractive and inviting. Beautiful lawns, shade trees and cheerful flowers and shrubs are inexpensive and easy to establish. Consider also the greatly heightened real estate value of the improved yard. For both your pleasure and profit it is distinctly worth while to "fix up" the home-yard surroundings.

\section{INSURE YOUR RESULTS.}

Your home-yard landscape improvements may be quite modest-possibly merely a tasteful planting about the house itself to soften the foundation lines and make the place look "homey." The beauty that is sought for will depend not upon the number of plants used, but more upon the choice of varieties and their arrangement. Even a very pretentious planting will fail in its purpose if it is done in a haphazard, hit-or-miss fashion. Thoughtful planning will make certain of happy results whether it is only for the ornamentation of the door yard or for the embellishment of a large estate.

\section{THE LANDSCAPE PLAN.}

The practical uses of the property as well as its increased attractiveness is considered in a well-made landscape plan. The environment, building architecture, soil, grading and exposure are some of the factors considered in arriving at a plan for the improvement of the place. In adopting a scheme that provides for surroundings of beauty and successfully meets these local conditions the owner can feel certain that every dollar spent on the yard development will be wisely invested to produce results.

\section{THE COST OF THE PLAN.}

Our customers can receive expert landscape advice for improving their home grounds without extra cost. When plans and specifications are delivered a charge in the amount of ten per cent of the cost of the plants that are needed is made. Later on when your order for the plants is entered, a credit in the amount of the plan charge is shown on the order. This method enables us by covering actual overhead expenses, to furnish worth-while landscape advice -something that will be of real merit and value to you.

For larger problems and for special trips and consultations, the charge for the landscape architect's services depends largely upon the time required. Cost estimates for this will be cheerfully given.

\section{HELPFUL LANDSCAPE SERVICE-ASK US ABOUT IT.}

Every owner wants his home grounds to be attractive, but frequently hesitates to undertake a work with which he is but vaguely familiar. To this end we offer you our "LANDSCAPE SERVICE" - ready to help in a practical way from plans to actual planting.

The men who advise you are trained and experienced and know from actual contact with Northern conditions just how to help you get the most satisfying results in an economical way. The planting material we offer is acclimated, hardy and suited to Northwest planting. Every plant must be of a fine grade and quality before leaving our nursery. You are invited to visit and inspect our nursery grounds and make

\section{personal selections if desired.}

\section{OUR OUT-OF-TOWN CUSTOMERS}

Your landscape problem can very often be solved directly from our office with the help of such data as you can easily furnish. This eliminates the need or expense of a special trip. Full information will be given in response to your inquiry.

\section{The PARK Nurseries HOLM \& OLSON, Inc. Landscape Architects}


PERMANENTLY BEAUTIFY YOUR YARD

Use Hardy Flowering Shrubs and Plant But Once



These sketches show how to arrange a planting about the house front. Some of the most popular and desirable hardy shrubs are used here in a way to produce the most pleasing results. The same list of plants applies to either plan.

The plant arrangements can be varied somewhat to meet slightly different conditions.

Use this collection of carefully selected flowering shrubs. All hardy varieties, best quality plants in substantial sizes.

\begin{tabular}{|c|c|c|}
\hline \multicolumn{3}{|r|}{ List of Shrubs Used } \\
\hline $\mathrm{KEY}$ & No. & VARIETY \\
\hline $\mathrm{A}$ & 2 & Bridal Wreath. 3 to $4 \mathrm{ft}$. \\
\hline B & 2 & Snowberry. 2 to $3 \mathrm{ft}$. \\
\hline C & 3 & Hydrangea. 2 to $3 \mathrm{ft}$. \\
\hline D & 4 & $\begin{array}{l}\text { Thunberg's Barberry. } \\
18 \text { to } 24 \text { ins. }\end{array}$ \\
\hline $\mathrm{E}$ & 3 & $\begin{array}{l}\text { Dwarf Crimson Spiraea. } \\
18 \text { to } 24 \text { ins. }\end{array}$ \\
\hline $\mathrm{H}$ & 1 & $\begin{array}{l}\text { Flowering Honeysuckle. } \\
4 \text { to } 5 \mathrm{ft} \text {. }\end{array}$ \\
\hline M & 2 & $\begin{array}{l}\text { Syringa, dwarf variety. } \\
2 \text { to } 3 \mathrm{ft} \text {. }\end{array}$ \\
\hline
\end{tabular}

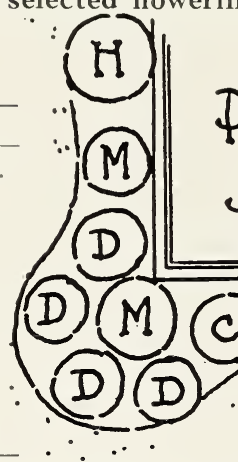

CHOICE ASSORTMENT, 17 HARDY SHRUBS, Catalogue value $\$ 13.55^{\circ}$

SPEGIAL "Get Acquainted" OFFER-ENTIRE COLLECTION

F. O. B. St. Paul. Packing Free

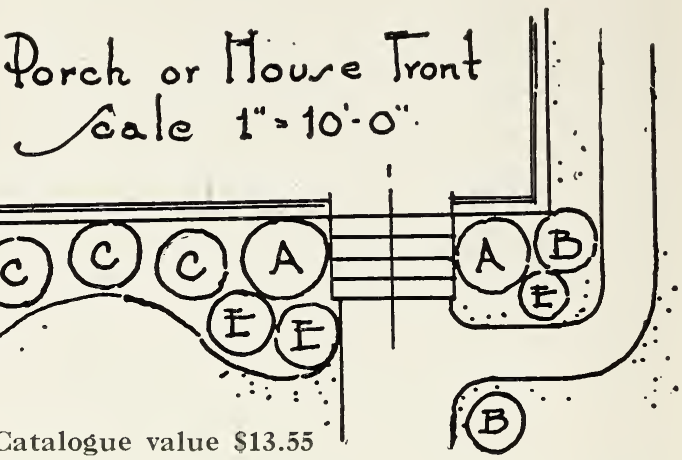

$\$ 11.00$

\section{MAKE YOUR BACK YARD INVITING}

Beautify the back-yard at small expense with this special collection of hardy, flowering shrubs.

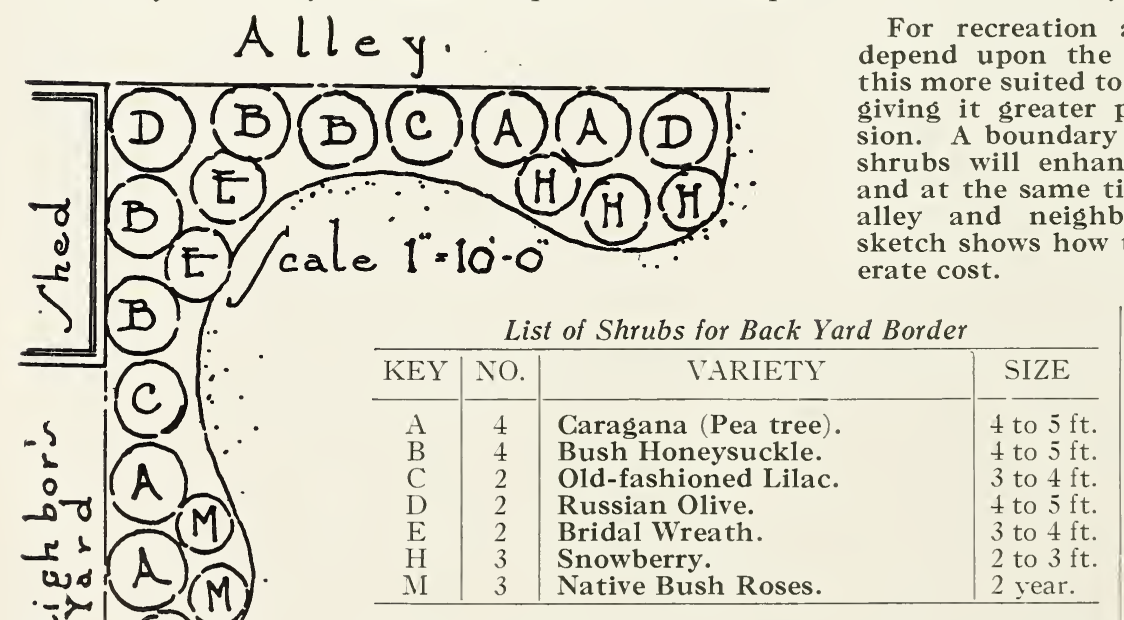

20 tall-growing, hardy shrubsenough for a border $\mathbf{5 0} \mathrm{ft}$. long.

A cata 1 og u e value of $\$ 19.30$.

SPECIAL COLLECTION-“Get Acquainted" OFFER F. O. B. St. Paul. Packing Free 


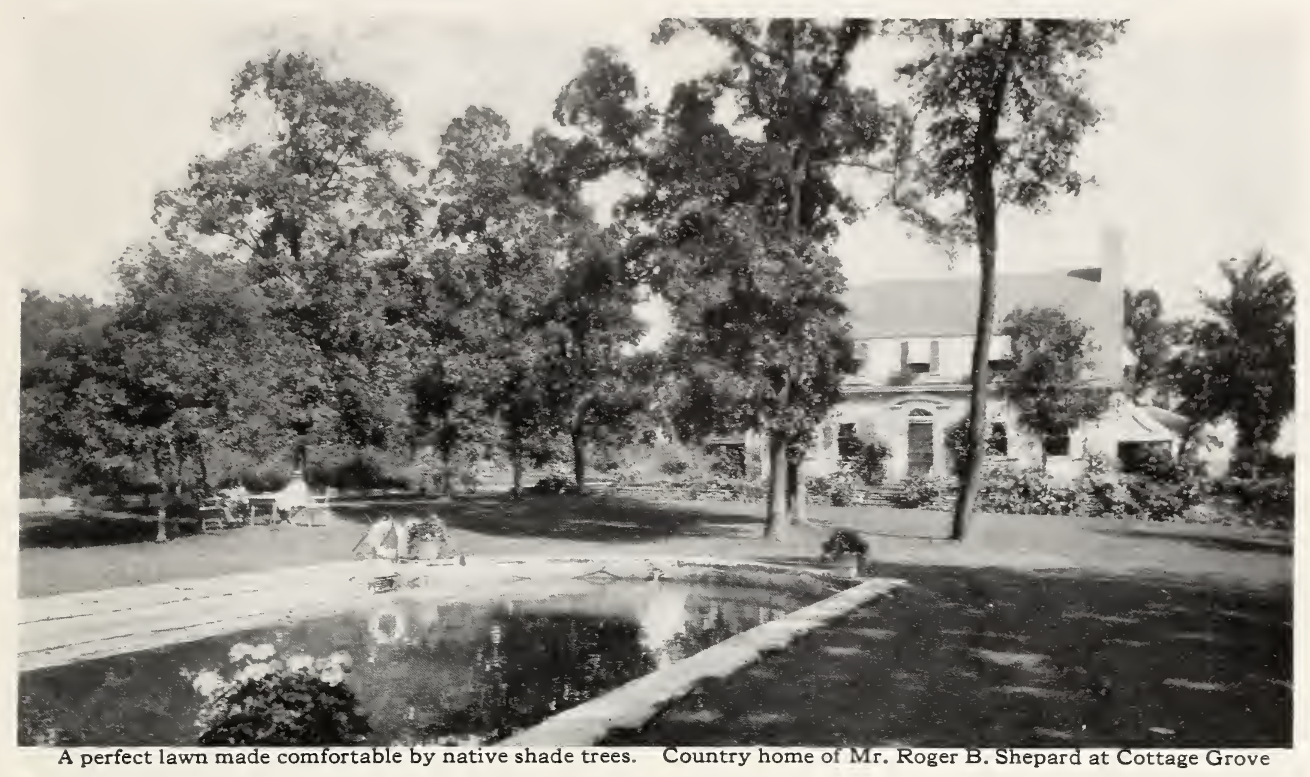

\section{HARDY TREES-For Shade and Beauty}

A few good shade trees are real essentials in making the home yard a source of beauty and comfort. Since they require several seasons to reach development it is doubly important to get them planted and making growth as soon as possible. For more complete variety descriptions of Trees, see our book "CREATING YOUR LANDSCAPE"-sent on request.

Ash, American White (Fraxinus Americana). A native shade and forest tree. Straight, clean growth. Few insect troubles. $70 \mathrm{ft}$. Each

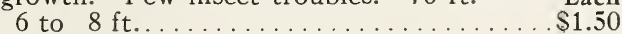


10 to $12 \mathrm{ft}$., $1 \frac{1}{2}$ to 2 in. diameter....... 3.50 10 to $12 \mathrm{ft}$., 2 to $21 / 2 \mathrm{in}$. diameter...... 4.50 12 to $14 \mathrm{ft}$., $21 / 2$ to 3 in. diameter....... 7.00

Basswood. See Linden, American.

Box Elder (Acer negundo).

A rapidly-growing, large tree. $40 \mathrm{ft}$.

6 to $8 \mathrm{ft}$..

8 to $10 \mathrm{ft}$

$\$ 1.25$

10 to $12 \mathrm{ft}, 11 / 2$ in. diameter

1.75

2.50

Birch, Cut Leaf Weeping.

White bark; graceful branches. $35 \mathrm{ft}$.

5 to $6 \mathrm{ft}$. .

6 to $8 \mathrm{ft}$.

8 to $10 \mathrm{ft}$. .

$\$ 4.00$

5.00

7.00

Birch, European White (Betula alba).

White bark; erect growth. $50 \mathrm{ft}$.

6 to $8 \mathrm{ft}$.

8 to $10 \mathrm{ft}$. .

4.00

Birch, Paper or Canoe (Betula Papyrifera). A hardy native with large leaves. $50 \mathrm{ft}$.

6 to $8 \mathrm{ft}$. .

Butternut (Juglans cinerea).

A hardy, nut producing tree. $70 \mathrm{ft}$.

6 to $8 \mathrm{ft}$. . .

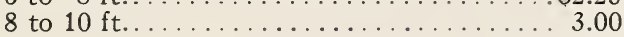

Catalpa Bungei. Umbrella Catalpa.

Rounded, umbrella-like tops on tall stem. Needs protection. $10 \mathrm{ft}$.

2 -yr. heads

3-yr. heads

Each

Catalpa, Western (Catalpa speciosa).

The hardiest of the Catalpas. White flowers. $50 \mathrm{ft}$.
6 to $8 \mathrm{ft}$
8 to $10 \mathrm{ft}$.
$\$ 1.50$
10 to $12 \mathrm{ft}$., $1 \frac{1}{2}$ to $2 \mathrm{in}$. diameter
2.00
2.75

Cherry, American Bird (Prunus serotina).

A native tree. White, fragrant flowers. Glossy leaves. Hardy. $50 \mathrm{ft}$.

5 to $6 \mathrm{ft}$.

6 to $8 \mathrm{ft}$.

$\$ 1.75$

8 to $10 \mathrm{ft}$.

Crab, Bechtel's Double Flowering.

Desirable lawn specimen. Covered in spring with rose-like pink flowers. $15 \mathrm{ft}$.

3 to $4 \mathrm{ft}$.

$\$ 2.00$

4 to $5 \mathrm{ft}$.

2.75

5 to $6 \mathrm{ft}$. . .

4.00

Crab, Floribunda (Malus floribunda).

Covered in spring with carmine pink flowers. Fruits ornamental. $15 \mathrm{ft}$.

3 to $4 \mathrm{ft}$. . .

4 to $5 \mathrm{ft}$. . .

2.75

Crab, Parkman's Flowering.

Flowers are of semi-double, rosy-white. $15 \mathrm{ft}$.

3 to $4 \mathrm{ft}$. .

4 to $5 \mathrm{ft}$.

3.75 


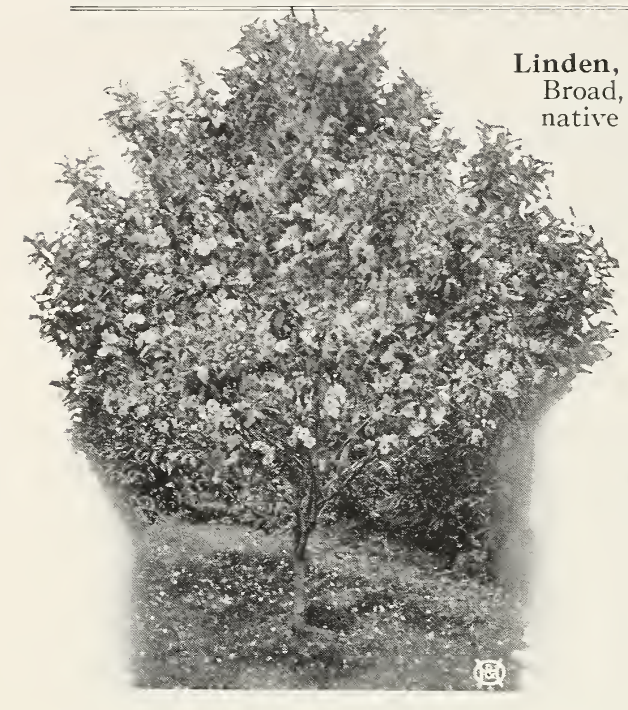

Bechtel's Flowering Crab

Crab, Soulard's (Malus Soulardi)

A hardy, native Crab beautiful in blossom and in fruit. $15 \mathrm{ft}$.

3 to $4 \mathrm{ft}$.

Each

4 to $5 \mathrm{ft}$.

$\$ 2.00$

5 to $6 \mathrm{ft}$

2.50

3.00

E1m, American (Ulmus Americana)

The most popular of shade, street and lawn trees. Very hardy. The fastest growing of the better trees. $60 \mathrm{ft}$.

6 to $8 \mathrm{ft}$.

$\$ 1.50$

8 to $10 \mathrm{ft}$.

2.00

10 to $12 \mathrm{ft} ., 11 / 2$ to 2 in. diameter.

10 to $12 \mathrm{ft}$., 2 to $21 / 2 \mathrm{in}$. diameter.

3.50

12 to $14 \mathrm{ft} ., 21 / 2$ to 3 in. diameter

5.00

12 to $14 \mathrm{ft} ., 3$ to $31 / 2$ in. diameter.

7.00

12 to $14 \mathrm{ft} ., 31 / 2$ to 4 in diameter.

9.00

12 to $14 \mathrm{ft} ., 4$ to 5 in. diameter...... 15.00

14 to $16 \mathrm{ft}$., 5 to 6 in. diameter........20.00

14 to $16 \mathrm{ft}$., 6 to 7 in. diameter......25.00

Specimen trees.

$\$ 30.00$ to 75.00

E1m, Camperdown.

A picturesque, weeping tree. $15 \mathrm{ft}$.

2 -yr. heads

$\$ 4.50$

3-yr. heads

6.50

Ginkgo or Maidenhair (G. Biloba).

Exotic in appearance. Leaves fan-shaped. $50 \mathrm{ft}$.

5 to $6 \mathrm{ft}$.

$\$ 2.75$

6 to $8 \mathrm{ft}$.

3.25

8 to $10 \mathrm{ft}$

4.50

Hackberry (Celtis occidentalis).

The foliage somewhat resembles the Elm. IVide spreading tops giving good shade. Very hardy. $50 \mathrm{ft}$.

6 to $8 \mathrm{t}$.

$\$ 2.00$

8 to $10 \mathrm{ft}$

3.00

10 to $12 \mathrm{ft}$

4.00

10 to $12 \mathrm{ft}$., 2 to $2 \frac{1}{2}$ in. diameter.

9.00

Specimen trees..............\$20.00 to 60.00

Horse-Chestnut-(Buckeye) (Aesculus).

Five-fingered leares. Yellow flowers in spikes. $40 \mathrm{ft}$.

5 to $6 \mathrm{ft}$.

$\$ 3.00$

6 to $8 \mathrm{ft}$.

4.00

8 to $10 \mathrm{ft}$.
$\$ 1.00$

1.50



Airy foliage; fragrant white flowers. $50 \mathrm{ft}$.

to $6 \mathrm{ft}$

Each

$\$ 2.25$

e, Ash-Leaved. See Box Elder.

Norway (Acer platanoides).

drome tree; rounded head; broad, dark-green leaves. A tree. $40 \mathrm{ft}$

to $8 \mathrm{ft}$.

$\$ 3.00$

to $10 \mathrm{ft}$

4.25

to $12 \mathrm{ft} ., 1 \frac{1}{2}$ in. diameter

6.00

$12 \mathrm{ft}$., 2 to $2 \frac{1}{2}$ in. diameter.

8.00

pecimen trees.

$\$ 30.00$ to 50.00

Maple, Purple Leaf (Acer platanoides Schwedleri). Leaves are bright reddish-purple in spring toning to a deep, purplish-green later. Highly prized for lawn planting. $40 \mathrm{ft}$.

6 to $8 \mathrm{ft}$. (slightly branched)

8 to $10 \mathrm{ft}$. (full branched) $1 \frac{1}{2}$ to $2 \mathrm{in}$. diameter

$\$ 4.00$

2 to $14 \mathrm{ft}$., $2 \frac{1}{2}$ to $3 \mathrm{in}$. diameter.

Maple, Silver (Acer dasycarpum)

Foliage light green, silvery beneath. Rapid growing. Succeeds anywhere. $50 \mathrm{ft}$.
6 to $8 \mathrm{ft}$
8 to $10 \mathrm{ft}$
$\$ 1.25$
10 to $12 \mathrm{ft} ., 1 \frac{1}{2}$ to 2 in. diameter
10 to $12 \mathrm{ft}$., 2 to $21 / 2$ in. diameter
2.75

Maple, Sugar (Acer saccharum).

A symmetrical tree of great beauty. Hardy native. Deeply-lobed, darkgreen leaves. Brilliant fall colors. $50 \mathrm{ft}$.

6 to $8 \mathrm{ft}$

8 to $10 \mathrm{ft}$.

10 to $12 \mathrm{ft} ., 11 / 2$ in. dia meter...... 5.00

10 to $12 \mathrm{ft}$., 2 to $21 / 2 \mathrm{in}$. diameter...... 7.50

10 to $12 \mathrm{ft} ., 2 \frac{1}{2}$ to $3 \mathrm{in}$. diameter... 9.00

Maple, Tartaria $\mathbf{n}$ (Acer tataricum Ginnala).

A splendid lawn ornamental. Beautiful red fall color. $18 \mathrm{ft}$.

3 to $4 \mathrm{ft}$. bushy.

4 to $5 \mathrm{ft}$. bushy.

\section{Maple, Wier's Cut-Leaf.}

A graceful lawn tree with delicately-cut leaves and drooping growth. $40 \mathrm{ft}$.

6 to $8 \mathrm{ft}$.

8 to $10 \mathrm{ft}$

10 to $12 \mathrm{ft} ., 1 \frac{1}{2} \mathrm{in}$. diameter

Specimen trees.

$\$ 20.00$ 
Mountain Ash, European (Sorbus aucuparia).

White flowers in May followed by bright, orangered berries. $30 \mathrm{ft}$.

Each



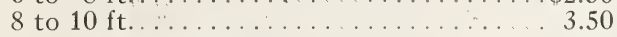

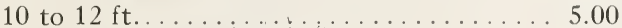

Mountain Ash, Weeping.

A drooping form of the above. $15 \mathrm{ft}$.

2-yr. head....................\$\$.75

Mulberry, Russian (Morus alba tatarica).

Rapidly growing, large leaves. Edible fruit. $25 \mathrm{ft}$.

5 to $6 \mathrm{ft} \ldots \ldots \ldots \ldots \ldots \ldots \ldots \ldots \ldots \ldots \ldots \ldots \ldots \ldots \ldots \ldots$

6 to $8 \mathrm{ft}, \ldots \ldots \ldots \ldots, \ldots \ldots \ldots$

Mulberry, Weeping.

A rounded top with weeping branches. $10 \mathrm{ft}$.

2 -yr, head

$\$ 4.75$

Oak, Pin (Quercus palustris).

Deeply-cut foliage with brilliant fall coloration. $50 \mathrm{ft}$.

5 to $6 \mathrm{ft}$.

$\$ 3.00$

6 to $8 \mathrm{ft}$

4.00

Plum, Double-Flowering (Prunus triloba).

Large, double pink, rose-like flowers in spring.

2 to $3 \mathrm{ft}$. .

$\$ 1.25$

3 to $4 \mathrm{ft}$.

1.50

4 to $5 \mathrm{ft}$.

2.00

Specimen trees.

$\$ 3.00$ to 5.00

Plum, Purple Leaf.

Dark-purple leaves all summer. Attractive lawn specimen. $10 \mathrm{ft}$.

3 to $4 \mathrm{ft}$.

4 to $5 \mathrm{ft}$.

5 to $6 \mathrm{ft}$.

$\$ 1.50$

2.00

3,00

Poplar, Balsam (Populus balsamifera).

Thick, glossy leaves; silvery beneath. Buds have balsam fragrance. $50 \mathrm{ft}$.

6 to $8 \mathrm{ft}$.

8 to $10 \mathrm{ft}$

Poplar, Bolleana (Populus bolleana).

Upright, columnar growth. Glossy-green leares with downy-white undersides. $30 \mathrm{ft}$.

6 to $8 \mathrm{ft}$.

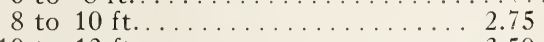

10 to $12 \mathrm{ft} . . . .3 .50$

Specimen trees.......... $\$ 10.00$ to 40.00

Poplar, Carolina (Populus monilifera).

Quick growth. Dense foliage. Grows anywhere. $50 \mathrm{ft}$.

6 to $8 \mathrm{ft}$.

$\$ 1.00$

10 to $12 \mathrm{ft}$.

1.50

2.00

Poplar, Lombardy (Populus fastigiata).

Erect and pyramidal in form. Planted for landscape effect. $40 \mathrm{ft}$.

6 to $8 \mathrm{ft} . \ldots \ldots \ldots$

8 to $10 \mathrm{ft} \ldots \ldots \ldots \ldots \ldots \ldots \ldots \ldots$

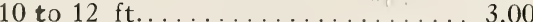

Specimen trees ........\$10.00 to 25.00

Poplar, Silver (Populus alba).

Leaves green above, white under-surface. $40 \mathrm{ft}$.

6 to $8 \mathrm{ft} \ldots \ldots \ldots \ldots \ldots \ldots \ldots \ldots \ldots$

8 to $10 \mathrm{ft} \ldots \ldots \ldots \ldots . .2 .00$
Walnut, Black (Juglans nigra).

A native tree of majestic proportions. Large leaves of 13 to 17 leaflets. Edible nuts. $70 \mathrm{ft}$.

5 to $6 \mathrm{ft}$.

Each

6 to $8 \mathrm{ft}$.

$\$ 1.50$

2.00

Willow, Golden (Salix vitellina aurea).

Rapidly growing with branches of rich golden yellow. Very hardy. $35 \mathrm{ft}$
6 to $8 \mathrm{ft}$
$\$ 1.00$
8 to $10 \mathrm{ft}$
1.50
10 to $12 \mathrm{ft}$

Willow, Laurel Leaf (Salix pentandra)

Glossy-green leaves. Grows rapidly. $30 \mathrm{ft}$.
6 to $8 \mathrm{ft}$
$\$ 1.00$
8 to $10 \mathrm{ft}$
1.50
10 to $12 \mathrm{ft}$
2.50

Willow, Niobe Weeping.

Golden-bark; pendulous branches. $30 \mathrm{ft}$.

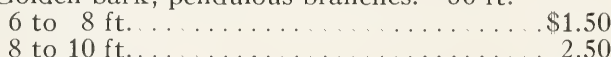

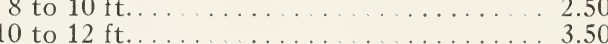

Willow, Pussy (Salix discolor).

Attractive in early spring when the fur-like buds swell out along the stems.

4 to $5 \mathrm{ft}$.

$\$ 2.00$

Willow, Wisconsin Weeping.

The hardiest of the weeping willows. Very desirable for a quick-growing, ornamental lawn specimen. $30 \mathrm{ft}$.
6 to $8 \mathrm{ft}$. . .
8 to $10 \mathrm{ft}$
10 to $12 \mathrm{ft}$ 


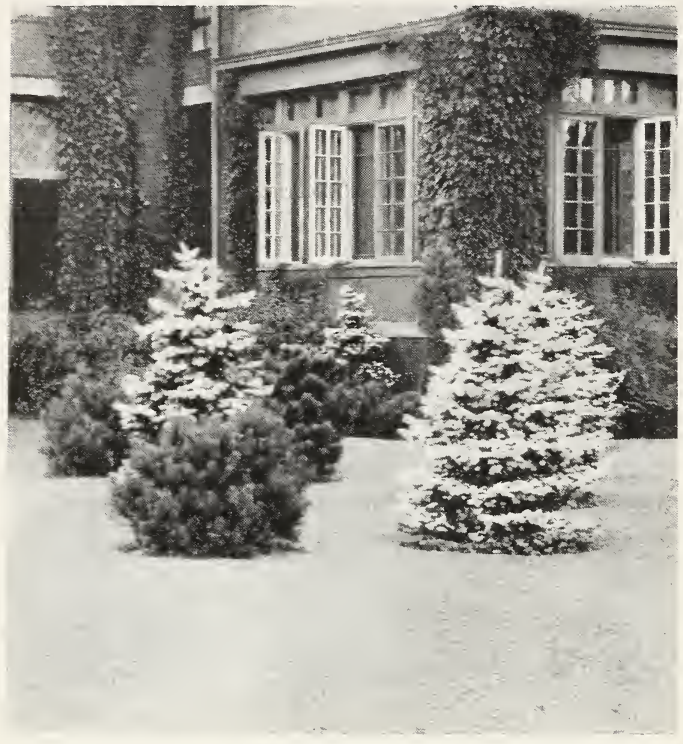

A group of Evergreens add all-year 'round beauty to the yard

Arborvitae, American (Thuja occidentalis).

A native tree with fan-shaped leaves. Foliage is soft and flexible, usually bushy at bottom and tapering toward top. Used very generally in plantings singly or with other evergreens. Stands trimming well to any size. $20 \mathrm{ft}$. Each 18 to 24 in

$\$ 2.50$

2 to $3 \mathrm{ft}$.

3.50

3 to $4 \mathrm{ft}$.

5.50

4 to $5 \mathrm{ft}$.

8.00

5 to $6 \mathrm{ft}$.

11.00

6 to $7 \mathrm{ft}$.

15.00

Specimen trees.

$\$ 15.00$ to 50.00

Arborvitae, Globe (Thuja occidentalis globosa).

A dwarf, bushy evergreen that grows naturally into a rounded, ball-like form. Keeps its rounded shape without trimming. Fine for low borders, foundation groups, tubs and urns. $4 \mathrm{ft}$.

12 to 18 in..

18 to 24 in.

$\$ 4.50$

2 to $3 \mathrm{ft}$.

Arborvitae, Pyramidal (Thuja occidentalis pyramidalis).

An attractive, solid pyramid of green that retains its shape without shearing. Seldom measures over 30 inches diameter at the base even when mature. $18 \mathrm{ft}$.

18 to 24 in.

2 to $3 \mathrm{ft}$.

$\$ 4.00$

3 to $4 \mathrm{ft}$. .

6.00

4 to $5 \mathrm{ft}$. .

9.50

5 to $6 \mathrm{ft}$.

12.00

Specimen trees.

16.00

Arborvitae, Siberian (Thuja Wareana Siberica).

A compact, dense, bushy evergreen, conical in outline; foliage rich dark green. The hardiest of the Arborvitaes. $8 \mathrm{ft}$.

18 to 24 in...

2 to $3 \mathrm{ft}$.

3 to $4 \mathrm{ft}$.

10.00

Cedar. See Juniper.

\section{HARDY EVERGREENS}

\section{An Important Part of \\ Your Planting}

Since the Evergreens retain their foliage continuously-are beautiful in appearance all four seasons of the year-they have an important value and use in landscape plantings. Their bright green is a note of great cheerfulness through the winter when all other plants are barren. During the summer too, their color and habit of growth make them distinctly attractive.

There are Evergreens to fit all requirements. Their diversity in outline, size, color and general appearance is so great that every home-owner can enjoy them for there are sorts appropriate to all uses. Indeed, an entire planting can be made of Evergreens alone without in any way becoming monotonous.

\section{Fir, Balsam (Abies balsamea)}

A hardy, native evergreen. Regular and symmetrical growth. Thrives in moist soils and cool climates. $40 \mathrm{ft}$.

2 to $3 \mathrm{ft}$.

Each

3 to $4 \mathrm{ft}$.

4 to $5 \mathrm{ft}$.

5 to $6 \mathrm{ft}$.

8.00

Specimen trees.

. 11.00

$\$ 15.00$ to 35.00

\section{How to Plant Evergreens}

Our Evergreens, all carefully handled so as to be in prime condition for moving, are dug with solid balls of earth, wrapped with burlap, on the roots. Early to late May is a favorable time for transplanting although late August moving is sometimes successful. A hole should be dug of ample size for the ball of earth. Place the tree in the hole, loosen and pull back burlap covering and after filling the hole two-thirds full of good soil, then flood with water and allow this to soak into the ground. Soil can then be filled in to nearly the ground level. Give the Evergreens plenty of water thruout the summer.

Ask our Landscape Department for suggestions to help you in arranging and selecting your evergreens for most attractive results.

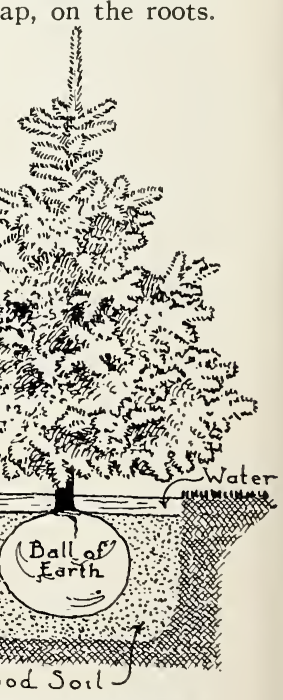

Showing how an Evergreen should be planted 
Fir, Douglas (Abies pseudotsuga Douglasi).

Quick growing tree of open, broad, sharp pointed pyramidal shape. Large bluish-green needles. A splendid ornamental evergreen where a large tree is wanted. $40 \mathrm{ft}$.

Each

2 to $3 \mathrm{ft}$

3 to $4 \mathrm{ft}$.

6.50

$t$ to $5 \mathrm{ft}$.

10.00

5 to $6 \mathrm{ft}$.

15.00

Fir, White or Silver (Abies concolor)

A very ornamental tree with long, broad needles. Color of leaves, grayish blue. Grows rapidly. The leaves are large, flat and closely backed on the branches. General outline of tree is a loose pyramid. $40 \mathrm{ft}$

2 to $3 \mathrm{ft}$.

\$7.50

3 to $4 \mathrm{ft}$.

10.00

Specimen trees

$\$ 30.00$ to 75.00

Juniper, Pfitzer's (Juniperus Pfitzeriana).

Branches horizontally spreading and slightly drooping. A graceful, bushy form suited to foreground plantings. $8 \mathrm{ft}$.

2 to $3 \mathrm{ft}$.

3 to $4 \mathrm{ft}$.

4 to $5 \mathrm{ft}$

$\$ 8.00$

12.00

18.00

25.00

5 to $6 \mathrm{ft}$.

Specimen trees

$\$ 30.00$ to 40.00

Juniper, Red Cedar (Juniperus sirginiana).

Pyramidal shape with rich green foliage. Probably the most useful of all ornamental evergreens because of its beauty, adaptability and hardiness. Stands trimming. $30 \mathrm{ft}$.

2 to $3 \mathrm{ft} . \$ 5.00$

3 to $4 \mathrm{ft}$........... 7.50

4 to $5 \mathrm{ft} .11 .00$

5 to $6 \mathrm{ft} \ldots \ldots \ldots 15.00$

6 to $7 \mathrm{ft} \ldots \ldots . . . . .18 .00$

7 to $8 \mathrm{ft} . \ldots \ldots 25.00$

Specimen trees $\$ 25.00-50.00$

Young Austrian Pine

Juniper, Savin's (Juniperus sabina).

Thickly branched, low, spreading tree. Can be trimmed. Excellent for use as a low bush in foreground plantings. $5 \mathrm{ft}$.

18 to 24 in.

ST.00

2 to $3 \mathrm{ft}$.

Juniper, Silver (Juniperus virginiana glauca).

Rich, silvery-gray foliage all season. Valued for its contrasting color when planted with other evergreens. $15 \mathrm{ft}$

2 to $3 \mathrm{ft}$.

$\$ 7.50$

3 to $4 \mathrm{ft}$.

10.00

4 to $5 \mathrm{ft}$.

13.00

5 to $6 \mathrm{ft}$.

17.00

6 to $7 \mathrm{ft}$.

20.00

Juniper, Swedish (Juniperus communis Suecica). Of a close-growing, columnar development. Highly ornamental. $10 \mathrm{ft}$.

18 to 24 in

2 to $3 \mathrm{ft}$.

6.50

Juniper, Trailing (Juniperus procumbens).

A dwarf evergreen shrub that grows closely to the ground. Suited to foreground plantings or for rock gardens.

18 to 24 in.

2 to $3 \mathrm{ft}$.
Pine, Austrian $(P i$ -

nus nigra).

Long, dark-green needles; vigorous growing. Very decorative, largegrowing evergreen. $60 \mathrm{ft}$. Each 2 to $3 \mathrm{ft}$.... $\$ 4.50$ 3 to $4 \mathrm{ft}$... 6.00

4 to $5 \mathrm{ft}$... 8.50

Pine, Dwarf Mugho (Pinus Montana mughus).

Desirable dwarf evergreen; bushy and globe-shaped.

Foliage deep green. Very hardy. $4 \mathrm{ft}$. Our best dwarf evergreen.

12 to 18 in.

18 to 24 in.

Bach

24 to 30 in

10.00

Pine, Scotch (Pinus syliestris).

An upright, rapidly-growing tree. Stiff, bluegreen foliage. Very picturesque in outline and an interesting specimen for evergreen groups. $40 \mathrm{ft}$.

2 to $3 \mathrm{ft}$.

$\$ 3.50$

3 to $4 \mathrm{ft}$.

4 to $5 \mathrm{ft}$

7.50

Pine, White (Pinus Strobus)

Our stately native Pine. Soft, light-green foliage. 3 to $4 \mathrm{ft}$.

4 to $5 \mathrm{ft}$

$\$ 5.50$

5 to $6 \mathrm{ft}$.

8.00

Specimen trees.

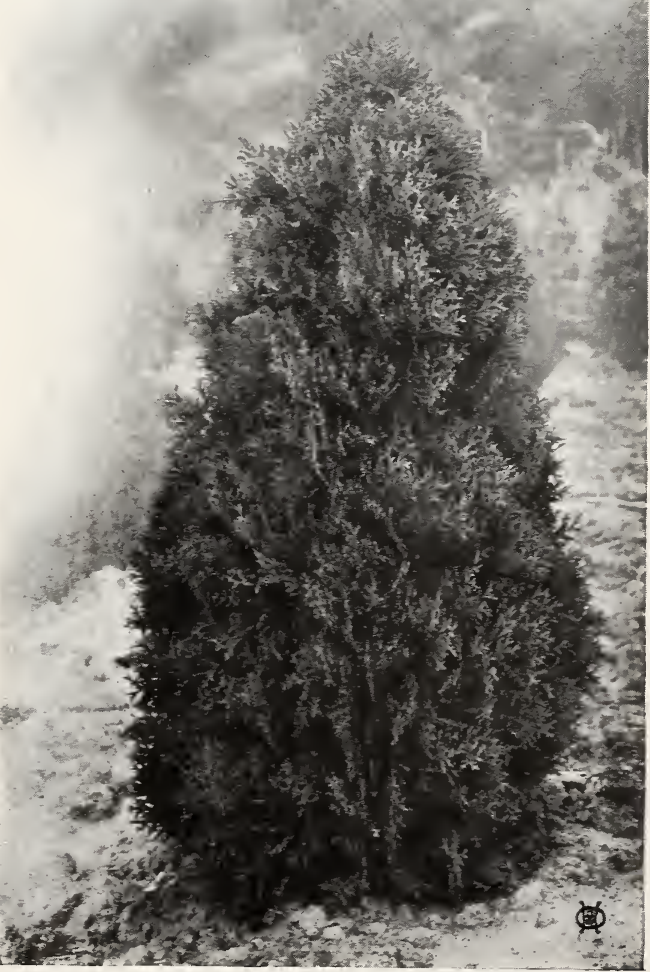

The Arborvitae has fan-like foliage 


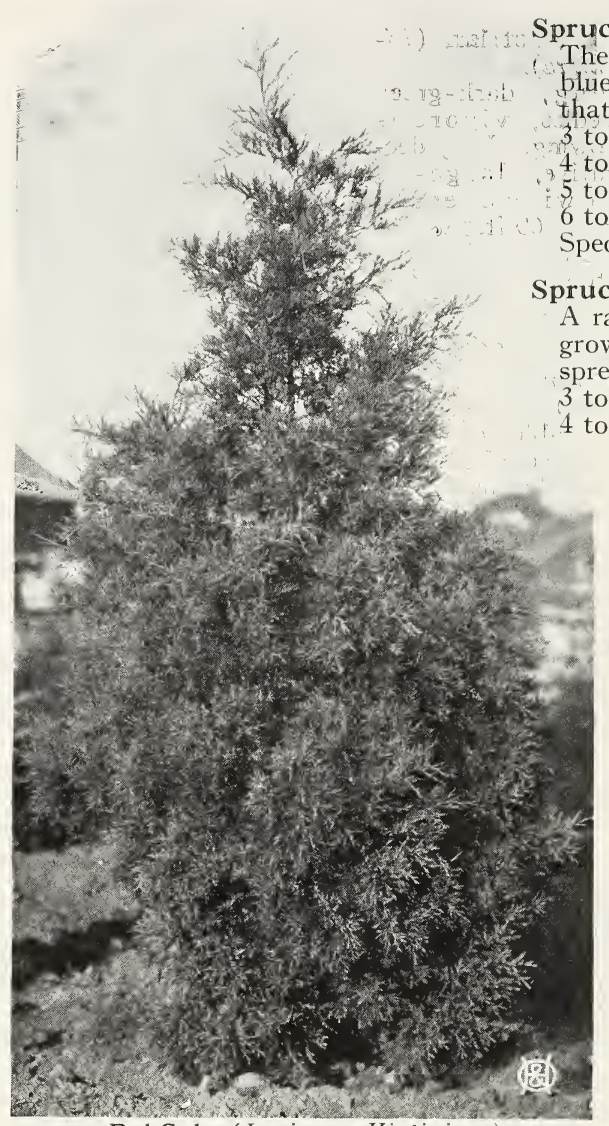

Red Cedar (Juniperus Virginiana)

Spruce, Blue Colorado (Picea pungens glauca).

A hardy American Spruce with rich silvery-blue foliage. Symmetrical growth. $35 \mathrm{ft}$. Each 18 to 24 in................... . $\$ 8.50$

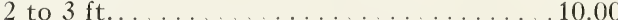

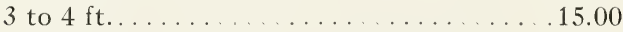

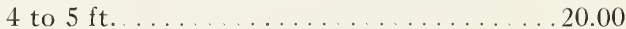

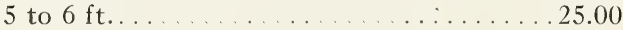

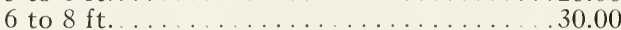

Spruce, Black Hills (Picea canadensis albertiana). A valuable, ornamental tree of close, dense growth. Stands dry soils and severe climatic conditions. Foliage varies from green to bluish color. $30 \mathrm{ft}$. 18 to 24 in...................... $\$ 4.00$

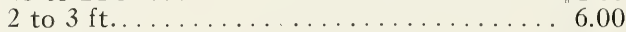

3 to $4 \mathrm{ft} \ldots \ldots \ldots \ldots \ldots \ldots \ldots \ldots . \ldots \ldots \ldots$

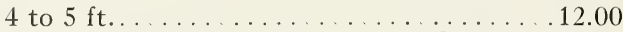

Specimen trees. ............. \$15.00 to 30.00

Spruce, Colorado (Picea pungens).

Very attractive in appearance with even, symmetrical growth and bluish-green foliage. Very hardy. i hrives almost anywhere and is always a:good lawn specimen. $35 \mathrm{ft}$.

2 to $3 \mathrm{ft}$.

$\$ 7.00$

3 to $4 \mathrm{ft}$.

9.00

4 to $5 \mathrm{ft}$.

13.00

5 to $6 \mathrm{ft}$.

18.00

Spruce, Douglas See Fir, Douglas.
7,50

10.00

15.00

5 to $6 \mathrm{ft}$.

6 to $7 \mathrm{ft}$.

$\$ 20.00$ to 45.00

Specimen trees.

Spruce, White (Picea canadensis).

A hardy, native tree of compact, upright growth.

Leaves have silvery-green appearance. $50 \mathrm{ft}$.

2 to $3 \mathrm{ft}$. . . .

3 to $4 \mathrm{ft}$.

4 to $5 \mathrm{ft}$.

5 to $6 \mathrm{ft}$.

10.00

Specimen trees............... \$15.00 to 50.00

Yew, Canadian (Taxus canadensis).

A shrub-like evergreen with spreading, slender branches. Dark green leaves. $3 \mathrm{ft}$.

12 to 18 in.

$\$ 4.00$

18 to $24 \mathrm{in}$.

6.00

24 to 30 in.

8.00

Yew, Japanese (Taxus cuspidata)

A small growing evergreen for foreground planting.

Longer leaves than the Canadian Yew. $3 \mathrm{ft}$.

12 to 18 in.

18 to 24 in.

$\$ 4.50$

24 to $30 \mathrm{in.}$

7.00

9.00 


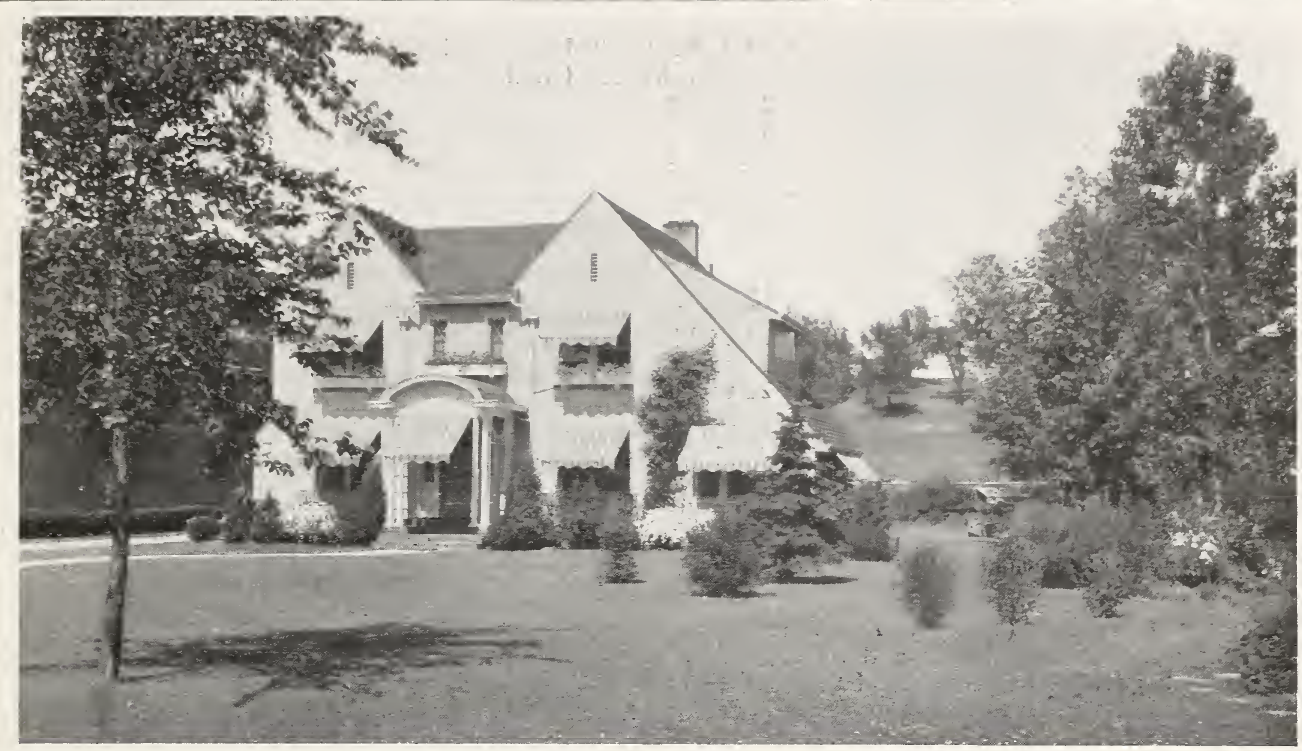

Through a proper planting scheme this house and its grounds are blended into a pleasing landscape picture. Residence of Mr. C. F. Aldrich

\section{HARDY FLOWERING SHRUBS}

\section{LOGATION IN THE YARD}

Suitable positions for shrubs in the home yard are many. The foundation and the angles and corners of the house should be softened by plantings of medium height shrubs, such as Spiraea (in variety). Snow berry, Hydrangea, Barberry and others of like nature. In the rear and side yard a border planting of taller shrubs such as Lilac, Honeysuckle, Mock Orange, etc., makes a beautiful property boundary as well as a screen from undesirable views. Other locations will be determined by the owner's wishes and the characteristics of the ground. Terraces can be planted, drives and walks bordered and bare lot-corners filled in

\section{How to Plant Shrubs}

Space the tall shrubs, such as Lilac, $t$ to 6 feet apart; the medium-height shrubs, such as Bridal IVreath, 3 to 4 feet apart; and the dwarf growers,

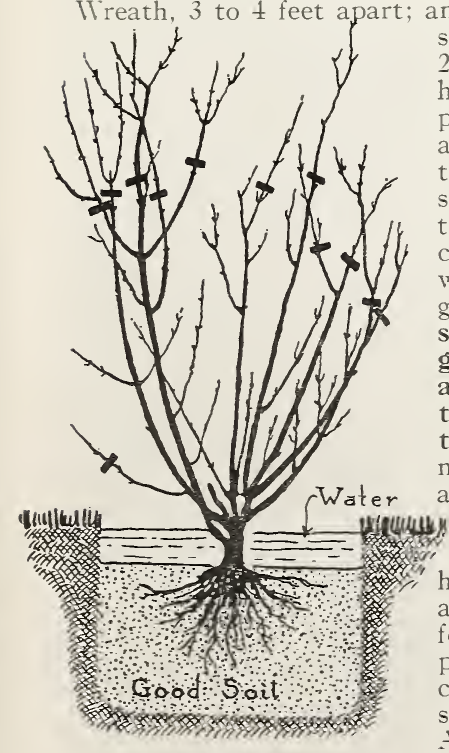

An ornamental shrub prop erly planted such as Barberry, 2 to $21 / 2$ feet apart. Dig the holes of ample size, place the plant and after filling in the hole two-thirds with topsoil, add water. Allow this to settle then complete the filling with soil up to the ground level. Always shorten back the top growth by cutting away at least onethe branches. Use no fertilizer excepting as a surface dressing.

Our Landscape Department will help you select and arrange your shrubs for best results on your property. For more complete descriptions see our book, "CREA T I I G Y O L R L.ANDSCAPE"- - sent on request. third the length of
Almond, Pink Flowering (Amygdalus Communis Rosea

Rose-like, pink flowers in early spring. Should be planted deeply to prevent sprouting of the plum root on which, for hardiness, this variety must be grown. 4 to $5 \mathrm{ft}$. Each

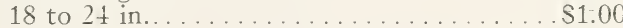

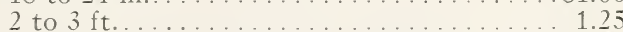

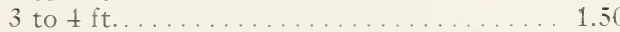

Specimen bushes.

S2.50 to 5.00

Almond, White Flowering (Amygdalus Communis Alba).

White-flowering variety of the above. 4 to $5 \mathrm{ft}$.

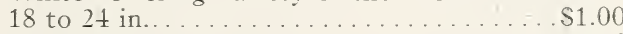

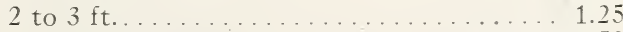



Specimen bushes...............S2.50 to 5.00

Amorpha Fruticosa. False Indigo.

Light foliage. Purple flowers. 5 to $6 \mathrm{ft}$.

2 to $3 \mathrm{ft}$.

3 to $+\mathrm{ft}$.

4 to $5 \mathrm{ft}$.

Aralia Chinensis. Hercules Club.

Tropical appearing bush with long, compound leaves. Needs protected situation. Branches are thorny. General appearance is upright and club-like. 8 to $10 \mathrm{ft}$ :

2 to $3 \mathrm{ft} \ldots \ldots \ldots \ldots \ldots \ldots \ldots \ldots \ldots \ldots \ldots \ldots$

3 to $t \mathrm{ft} \ldots \ldots \ldots . .25$

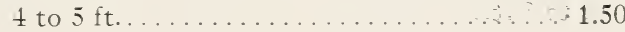




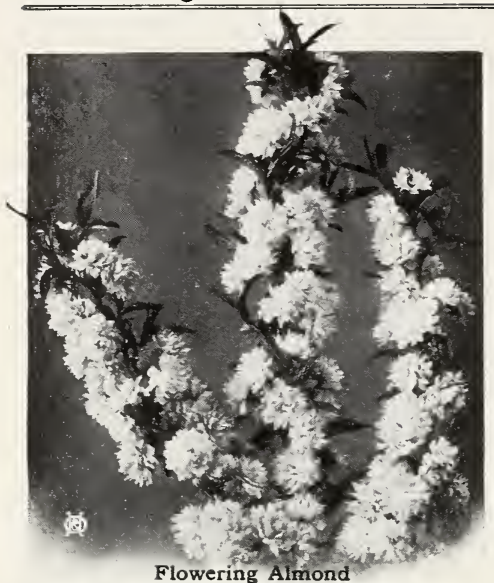

Buckthorn, Common (Rhamnus cathartica).

Very hardy. Lustrous leaves and black berries. Desirable in groups or for hedges. 8 to $10 \mathrm{ft}$. Each 18 to 24 in

2 to $3 \mathrm{ft}$.

$\$ 0.40$

3 to $4 \mathrm{ft}$

.50

4 to $5 \mathrm{ft}$.

.70

Specimen shrubs.

$\$ 1.50$ to $\$ 2.00$

Buckthorn, Carolina. Indian Cherry.

A hardy, decorative shrub with dark-green oblong leaves. Fruit red changing to black. $10 \mathrm{ft}$.

2 to $3 \mathrm{ft}$.

$\$ 0.50$

3 to $4 \mathrm{ft}$.

.70

Caragana. See Siberian Pea Tree.

Chokeberry (Aronia arbutifolia).

White flowers, bright red berries. 6 to $8 \mathrm{ft}$.

2 to $3 \mathrm{ft}$.

3 to $4 \mathrm{ft}$.

$\$ 1.00$

4 to $5 \mathrm{ft}$.

1.25

1.50

Glethra Alnifolia. Sweet Pepper Bush. Fragrant white flowers in September. 4 to $5 \mathrm{ft}$. 18 to 24 in.

0.80

2 to $3 \mathrm{ft}$.

$\$ 1.00$

Coral Berry (Symphoricarpus vulgaris).

Stands sun or shade and poor soil. . Red to purple berries in late summer. A native shrub that is hardy and easy to grow where other plants fail. 3 to $4 \mathrm{ft}$.

18 to 24 in.

2 to $3 \mathrm{ft}$.

3 to $4 \mathrm{ft}$.

$\$ 0.50$

.60

.80

Cotoneaster Acutifolia. Quince Berry.

Dense growing with ornamental, dark, glossy-green leaves. Stands shade. Very desirable for foundation plantings where a neat, dignified effect is wanted. $6 \mathrm{ft}$.

18 to 24 in.

2 to $3 \mathrm{ft}$. .

3 to $4 \mathrm{ft}$.

Cranberry, High-Bush. See Viburnum opulus.

Currant, Mountain (Ribes alpinum).

Dwarf shrub. Dense growth. Stands shade. One of the best low to medium height shrubs for planting under most all conditions. $4 \mathrm{ft}$.

12 to $18 \mathrm{in}$.

18 to 24 in.

2 to $3 \mathrm{ft}$.
1.00
Currant, Yellow Flowering. (Ribes aureum)

Large, yellow, fragrant flowers in early spring. Black, edible berries. Stands shade. $6 \mathrm{ft}$.

2 to $3 \mathrm{ft} \ldots \ldots \ldots \ldots \ldots \ldots \ldots \ldots \ldots . \ldots \ldots$

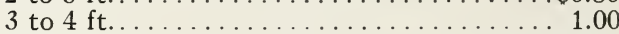

4 to $5 \mathrm{ft}$...

Specimen shrubs............ $\$ 2.50$ to 4.00

Deutzia Gracilis. Slender Deutzia.

White flowers in June. Needs protection. $21 / 2 \mathrm{ft}$.

12 to 18 in..................... $\$ 1.00$

18 to 24 in.

1.25

Deutzia, Pride of Rochester (D. Scabra).

Double, white flowers in May. $6 \mathrm{ft}$.

2 to $3 \mathrm{ft}$. .

3 to $4 \mathrm{ft}$.

Dogwood, Golden Twig (Cornus Siberica aurea).

Valued for its bright yellow branches in fall and winter. White flowers. $6 \mathrm{ft}$.

2 to $3 \mathrm{ft}$.

3 to $4 \mathrm{ft}$.

4 to $5 \mathrm{ft}$.

andscape Suggestions.

We can help you secure the best possible results in your planting work. Tell our "Landscape Service Department" of your plans and problems.

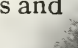




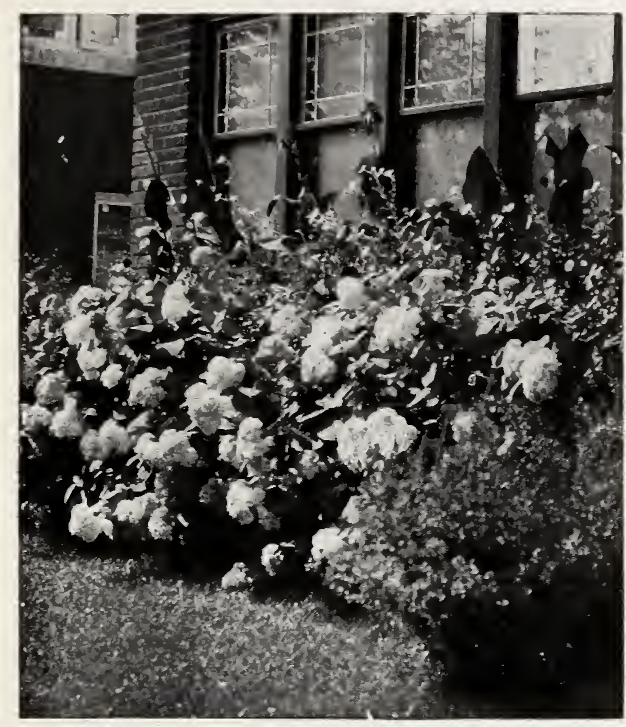

Hydrangea (Snowball) in a foundation planting

Dogwood, Gray-Bark (Cornus paniculata).

White flowers in early spring; gray bark. Good clean foliage. White berries in fall. $9 \mathrm{ft}$. Each

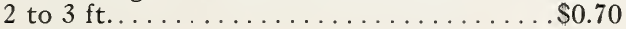
3 to $4 \mathrm{ft}$.

.90

Dogwood, Red Osier (Cornus stolonifera). A native species with slender, red branches. White berries. $7 \mathrm{ft}$.

18 to 24 in.

$\$ 0.50$

2 to $3 \mathrm{ft}$.

.60

3 to $4 \mathrm{ft}$.

.80

4 to $5 \mathrm{ft}$.

1.25

Dogwood, Red-Twigged (Cornus Siberica alba).

White flowers in June. The red stems are highly attractive during the winter. Old wood should be kept out and new growth encouraged to get best color. 6 to $8 \mathrm{ft}$.

2 to $3 \mathrm{ft}$.

$\$ 0.60$

3 to $4 \mathrm{ft}$.

.80

4 to $5 \mathrm{ft}$.

1.25

Dogwood, Silver (Cornus elegantissima).

Highly decorative because of its white-striped green leaves and red bark. $6 \mathrm{ft}$.



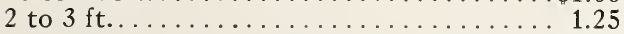

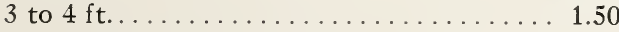

Elder, Black-Fruited (Sambucus canadensis).

Heavy, broad, clusters of fragrant, white flowers in July. Edible, black fruit. A very rapidly growing hardy shrub. Stands partial shade. $6 \mathrm{ft}$.

2 to $3 \mathrm{ft} \ldots \ldots \ldots \ldots \ldots \ldots \ldots \ldots \ldots \ldots$

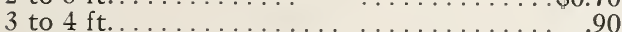

4 to $5 \mathrm{ft} \ldots \ldots \ldots \ldots \ldots \ldots \ldots \ldots \ldots \ldots \ldots \ldots \ldots \ldots .25$

Elder, Cut-Leaved (Sambucus nigra laciniata).

Divided, fern-like leaves. Stands shade. The delicate foliage makes a pleasing contrast when planted with other shrubs. 5 to $6 \mathrm{ft}$.

18 to 24 in...................... \$0.60

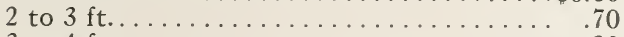

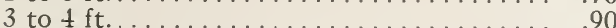

4 to $5 \mathrm{ft} \ldots \ldots \ldots \ldots \ldots \ldots \ldots \ldots \ldots \ldots$
Elder, Golden (Sambucus aurea).

The golden leaves hold their color well all season through. White flowers. $7 \mathrm{ft}$.

18 to 24 in ................... \$0.60

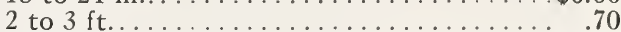

3 to $4 \mathrm{ft} \ldots \ldots \ldots \ldots \ldots \ldots \ldots \ldots . .90 \ldots \ldots$

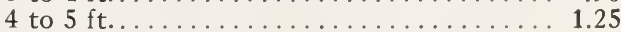

Elder, Red-JBerried (Sambucus racemosa).

Bright red berries in July. Stands shade. $8 \mathrm{ft}$.

18 to 24 in .................. \$ $\$ 0.60$

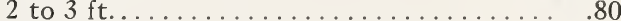

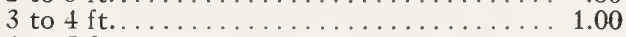

4 to $5 \mathrm{ft} . \ldots \ldots \ldots \ldots \ldots \ldots \ldots \ldots \ldots \ldots$

Specimen shrubs.

$\$ 2.50$ to 3.50

Elaeagnus. See Russian Olive.

Euonymus Americanus. Strawberry Bush.

Erect growing to $8 \mathrm{ft}$. Slender, green branches.

Ornamental pink fruits in the fall.



3 to $4 \mathrm{ft} . \ldots \ldots \ldots \ldots \ldots \ldots \ldots \ldots \ldots \ldots$

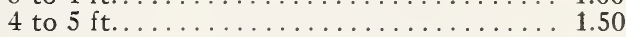

Euonymus Alatus. Winged Burning Bush. Curiously winged branches. Brilliant fall coloration in foliage and fruit. $7 \mathrm{ft}$.

2 to $3 \mathrm{ft}$....

3 to $4 \mathrm{ft}$.

4 to $5 \mathrm{ft}$.

Forsythia, Susyensa. Golden Bell.

Pendulous in habit. Lustrous, dark foliage. Golden flowers in April. Needs protection. $5 \mathrm{ft}$.

2 to $3 \mathrm{ft}$.

$\$ 0.60$

3 to $4 \mathrm{ft}$.

Forsythia Virdissima. Green-stem Golden Bell. Erect, green branches. Needs protection. $7 \mathrm{ft}$.

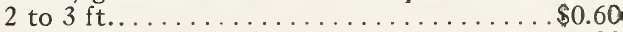
3 to $4 \mathrm{ft}$.

Fringe, Purple. Mist Tree (Rhus cotinus). Light, mist or smoke-like, blooming appearance in summer. Needs protection. $10 \mathrm{ft}$. 2 to $3 \mathrm{ft}$.

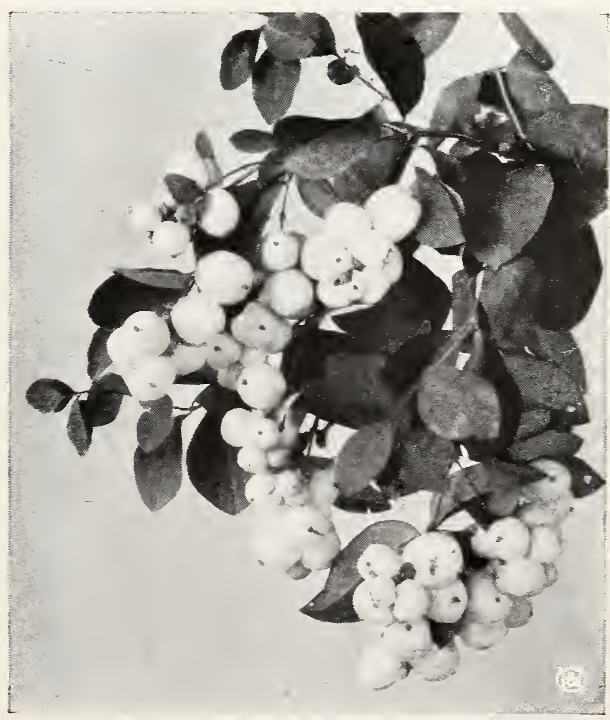

Ornamental fruit of the Snowberry 


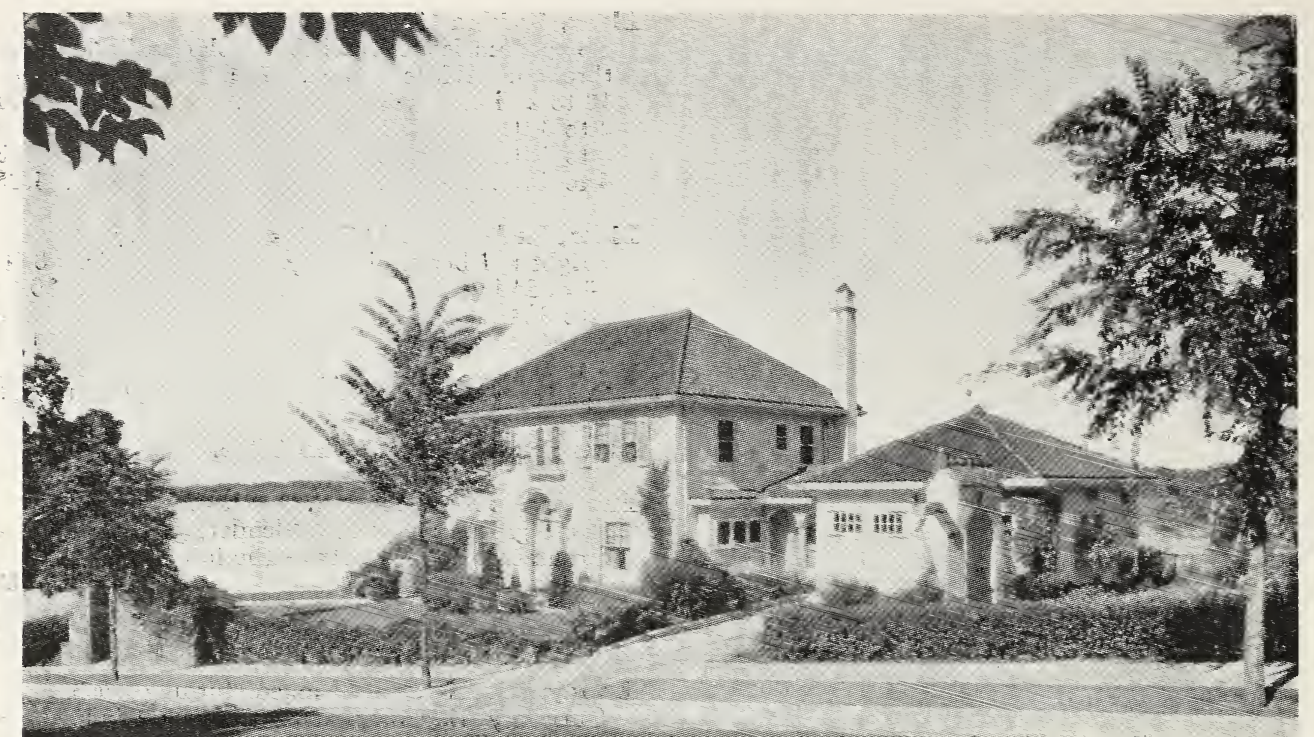

A restrained landscape planting is admirably suited to this attractive house and its lake exposure. Home-of Mr.

Hawthorn. See Thorn Apple.

Honeysuckle, Belle (Lonicera bella albida).

White fllowers; large red berries. $6 \mathrm{ft}$. Each 2 to $3 \mathrm{ft}$.

S0.60

Honeysuckle, Morrow's (Lonicera Morrowi).

Hardy shrub with wide-spreading branches. Yellowish-white flowers. Brilliant red berries in July. One of the best all around shrubs for the home yard.

Thrives in sun or shade, wet or dry places. $6 \mathrm{ft}$.

2 to $3 \mathrm{ft}$.

3 to $4 \mathrm{ft}$. .

S0.60

4 to $5 \mathrm{ft}$

.80

1.25

Honeysuckle, Pink (Lonicera tatarica rosea).

Quantities of pink to red flowers in spring. The fruit is a red berry that colors the bush in July and August. A long-lived and very popular shrub that is always ornamental. Easy to grow. $8 \mathrm{ft}$. 18 to 24 in..

\$0.50

2 to $3 \mathrm{ft}$.

3 to $4 \mathrm{ft}$.

4 to $5 \mathrm{ft}$.

.60

Specimen shrubs.

1.25

$\$ 1.50$ to 3.00

Honeysuckle, White (Lonicera tatarica alba).

Desirable white-flowering, bush honeysuckle. $8 \mathrm{ft}$.

2 to $3 \mathrm{ft}$........

3 to $4 \mathrm{ft}$.

S0.60

4 to $5 \mathrm{ft}$.

.80

5 to $6 \mathrm{ft}$.

1.25

Specimen shrubs

1.50

Hydrangea, Large-Flowered ( $H$. paniculata grandiflora).

Conical, flower-heads of white which later change to pink in August and September. Always wanted in home yard plantings because of the large flowers when other shrubs are out of bloom. $4 \mathrm{ft}$.

18 to 24 in.

S0.80

2 to $3 \mathrm{ft}$. . .

1.00

3 to $4 \mathrm{ft}$.

1.25
Hydrangea, Snowball (H. arborescens grandiflora). Heary, snowball-like flowers of white from late June to frost. Makes a pleasing compact bush with large leaves. Should have plenty of water. Stands partial shade. 3 to $4 \mathrm{ft}$. Each

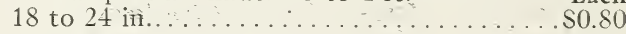
2 to $3 \mathrm{ft}$. .

1.00

3 to $t \mathrm{ft}$. 1.25

Hydrangea, Tree.

A tree form of the large-flowered fall-Hydrangea.

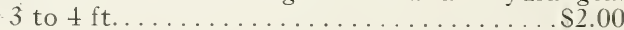

4 to $5 \mathrm{ft}$.

Juneberry (Amelanchier alnifolia).

$I^{t}$ hite flowers in May. Black berries. 5 to $8 \mathrm{ft}$. 2 to $3 \mathrm{ft}$.

so. 80

Lilac, French Hybrid Varieties.

Improved sorts that have heavier flowers than the common purple and white, and in a wider range of colors. 6 to $8 \mathrm{ft}$.

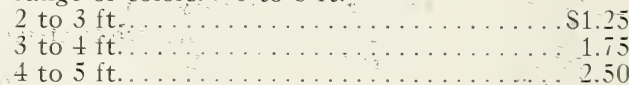

Charles X. Reddish purple; large.

Congo. Large heads, deep-purple flowers.

Ludwig Spaeth. Dark purplish-red.

Marie Legraye. One of the finest white Lilacs.

Michel Buchner. Dwarf; pale-lilac.

Madame Lemoine. Pure white.

President Carnot. Light lilac.

President Grevy. A beautiful blue.

Rubra De Marly. Purplish red; fine.

Lilac, Hungarian (Syringa Josikaea).

Light, violet-colored flowers in June. After the common Lilacs have finished blooming. $\delta$ to $10 \mathrm{ft}$.

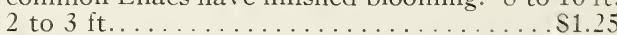

3 to $4 \mathrm{ft} \ldots \ldots \ldots \ldots \ldots \ldots \ldots \ldots \ldots \ldots . \ldots \ldots$

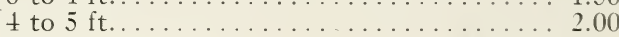

Specimen shrubs............. \$3.00 to 5.00 


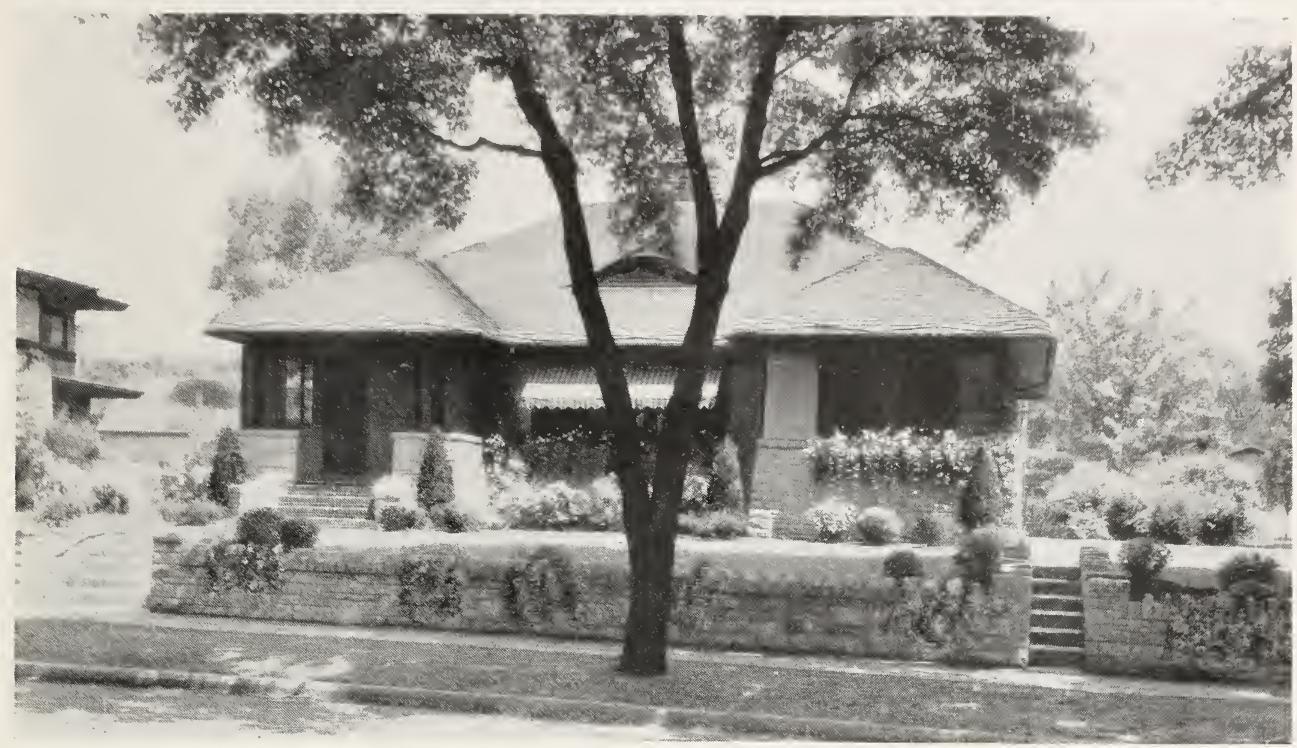

This uncommon wall treatment takes the place of a steep terrace and adds six feet of useful lawn space to the lot. Residence of Dr. C. H. Beers, Saint Paul

Lilac, Japanese Tree (Syringa Japonica).

Small tree in habit of growth. Flowers come in loose clusters of creamy-white, in June, $15 \mathrm{ft}$. Each

2 to $3 \mathrm{ft}$.

3 to $4 \mathrm{ft}$.

\pm to $5 \mathrm{ft}$.

Specimen shrubs

$\$ 1.00$

1.25

1.75

$\$ 2.00$ to 5.00

Lilac, Late Flowering (Syringa villosa).

Bushy, upright growth. Rich dark foliage with pinkish-lilac flowers in June. A desirable, hardy shrub ornamental both in and out of flower. $8 \mathrm{ft}$.

2 to $3 \mathrm{ft}$.

$\$ 1.25$

3 to $4 \mathrm{ft}$.

1.50

4 to $5 \mathrm{ft}$.

2.00

Specimen shrubs

$\$ 2.00$ to 5.00

Lilac, Persian (Syringa persica).

Slender growth; smaller leaves than the Common Lilac. Pale purple flowers in May. $7 \mathrm{ft}$.

2 to $3 \mathrm{ft}$.

$\$ 1.00$

3 to $4 \mathrm{ft}$.

1.35

4 to $5 \mathrm{ft}$.

1.75

Specimen shrubs

$\$ 2.50$ to 5.00

Lilac, Persian White (Syringa persica alba).

Similar to the preceding, almost thite blossoms.

2 to $3 \mathrm{ft}$.

$\$ 1.25$

3 to $4 \mathrm{ft}$.

1.50

Lilac, Purple (Syringa vulgaris).

The well-known, old-fashioned Lilac. Fragrant flowers in May. 9 to $12 \mathrm{ft}$.

2 to $3 \mathrm{ft}$. .

3 to $\pm \mathrm{ft}$.

1.25

4 to $5 \mathrm{ft}$.

Specimen shrubs.

$\$ 1.50$ to 3.00

Lilac, White (Syringa vulgaris alba).

A white-flowering Lilac. 9 to $12 \mathrm{ft}$.

2 to $3 \mathrm{ft}$

$\$ 0.70$

3 to $t \mathrm{ft}$

.90

4 to $5 \mathrm{ft}$.

1.25

Specimen shrubs.

i. $\$ 1.50$ to 5.00
Locust, Pink Flowering (Robinia hispida).

Showy rose-colored flowers in June. $5 \mathrm{ft}$. Each 2 to $3 \mathrm{ft}$.

3 to $4 \mathrm{ft}$.

$\$ 1.00$

1.25

Matrimony Vine (Lycium chinensis).

Esed to cover slopes or to "face-down" taller shrubs. Brilliant red berries over winter. 2 to $3 \mathrm{ft}$.

3 to $4 \mathrm{ft}$

Specimen shrubs

$\$ 1.00$ to 2.00

Mock Orange. See Philadelphus.

Philadelphus Aurea. Golden Mock-orange.

Bright, golden-yellow foliage. $3 \mathrm{ft}$.

12 to 18 in.

So.90

18 to 24 in.

1.25

2 to $3 \mathrm{ft}$

1.50

Philadelphus, Avalanche. Hybrid Mock-orange. Slender, arching branches heavily laden with showy white flowers. Fragrant. $\pm \mathrm{ft}$.

18 to $2 t$ in.

$\$ 0.60$

2 to $3 \mathrm{ft}$.

Philadelphus Coronarius. Sweet Mock-orange. Flowers are pure white and very fragrant in May and June. Good foliage. Quite a large and hardy old-fashioned shrub that is well placed as a lawn specimen or as a screen planting. $7 \mathrm{ft}$.

2 to $3 \mathrm{ft}$. .

$\$ 0.60$

3 to $4 \mathrm{ft}$. .

4 to $5 \mathrm{ft}$.

.80

Specimen shrubs.

$\$ 1.50$ to 3

Philadelphus Grandiflora. Large flowerế Mockorange.

Large white flowers and broad leaves, Has great value for screening or wherever a tall, heavy shrub is wanted. $9 \mathrm{ft}$.

2 tö 3 ft.

$\$ 0.60$

3 to $4 \mathrm{ft}$.

.80

4 to $5 \mathrm{ft}$.

1.25 


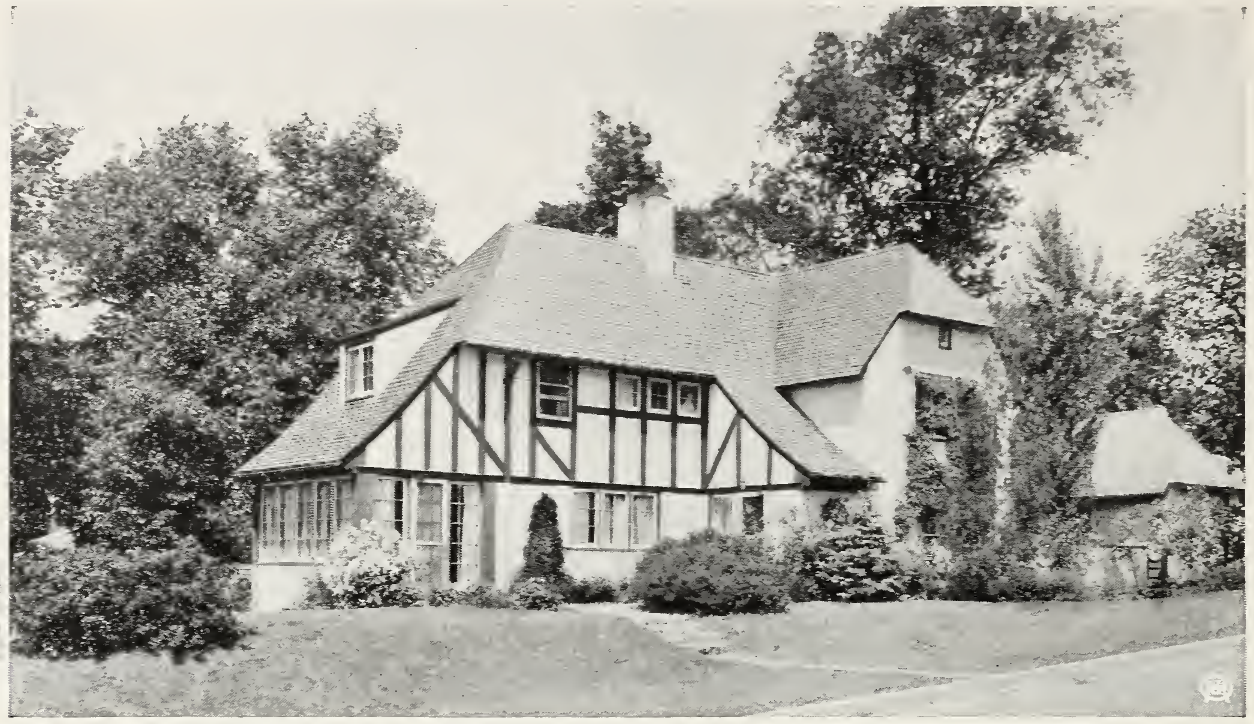

The grounds about the home of Mr. Beaver Wade Day of Saint Paul are made attractive through well-placed plantings

Philadelphus Lemoinei. LeMoine's Mock-orange. Medium height, very useful for foundation plantings. Fragrant white flowers. $5 \mathrm{ft}$. Each 18 to 24 in..................... \$0.60

2 to $3 \mathrm{ft}$.

.80

3 to $4 \mathrm{ft}$.

Specimen shrubs

Philadelphus, Mont Blanc. Hybrid Mock-orange.

A new variety, large, fragrant flowers. Medium height. A good shrub for house foundation plantings. $4 \mathrm{ft}$.

2 to $3 \mathrm{ft}$.

$\$ 0.80$

\section{Plum, Double-Flowering.}

Large, double, pink, rose-like flowers in early spring. Brilliant and remarkable in bloom. Hardier than the flowering almond. $5 \mathrm{ft}$.

2 to $3 \mathrm{ft}$. . .

$\$ 1.25$

3 to $4 \mathrm{ft}$.

1.50

4 to $5 \mathrm{ft}$.

2.00

Specimen shrubs.

$\$ 3.00$ to 5.00

Plum, Purple-Leaf. Variety Newport.

Dark purple leaves. Holds purple color all summer and makes a bright contrast with other foliage. $10 \mathrm{ft}$.

3 to $4 \mathrm{ft}$.

$\$ 1.50$

4 to $5 \mathrm{ft}$

2.00

5 to $6 \mathrm{ft}$.

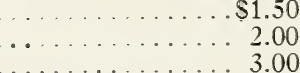

Potentilla Fruticosa. Cinquefoil.

Low shrub; yellow flowers all summer. $2 \mathrm{ft}$.

12 to 18 in.

18 to 24 in

$\$ 0.50$

2 to $3 \mathrm{ft}$.

Quince, Japan (Cydonia Japonica).

Bright, scarlet flowers in early spring. Bushy growth. Plant only in very protected positions. $6 \mathrm{ft}$.

2 to $3 \mathrm{ft}$.

$\$ 0.90$
Rugosa Rose (Rosa rugosa).

A very hardy bush rose that needs no winter covering. Dark green crinkled foliage and bright pink flowers make it exceedingly ornamental. Bright scarlet fruits appear during late summer and fall.

2-yr. plants.

Each

3-yr. plants

$\$ 0.80$

Roses. Bush varieties. See pages 31 and 32

Russian Olive (Elaeagnus angustifolia).

Silvery, willow-like leaves. Fragrant yellow flowers followed by yellow fruits. Used in plantings for its silvery foliage and good size. Very hardy. $12 \mathrm{ft}$.

2 to $3 \mathrm{ft}$.

$\$ 0.60$

3 to $4 \mathrm{ft}$

4 to $5 \mathrm{ft}$.

1.00

5 to $6 \mathrm{ft}$.

1.50

Siberian Pea Tree (Caragana arborescens).

Bright green, pea-like leaves. Clusters of yellow flowers in May followed by long slender seed pods. Very hardy and will stand dry locations and poor soils. $8 \mathrm{ft}$.

2 to $3 \mathrm{ft}$.

3 to $4 \mathrm{ft}$.

$\$ 0.60$

4 to $5 \mathrm{ft}$.

5 to $6 \mathrm{ft}$.

.80

1.25

Specimen shrubs.

1.50

Snowball. See Viburnum Snowball.

Snowberry, Red. See Coral Berry.

Snowberry, White (Symphoricarpus racemosus).

Medium height shrub. Stands shade. Large, waxy berries in September that persist well into the winter. A graceful and pleasing bush. $4 \mathrm{ft}$.

2 to $3 \mathrm{ft}$.

3 to $4 \mathrm{ft}$.

$\$ 0.60$

Specimen shrubs........... $\$ 1.50$ to 3.00 
Spiraea, Anthony Waterer. Crimson Spiraea. A very free flowering dwarf shrub of compact form. Crimson flowers all summer. Always blooms the first season. Makes a fine color combination planted with Hydrangea Snowball. $2 \mathrm{ft}$.

Each

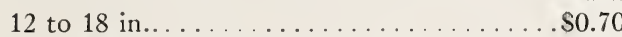



24 to 30 in..................... 1.25

Spiraea, Arguta. Garland Spiraea.

Many small, white flowers in May. $4 \mathrm{ft}$.

2 to $3 \mathrm{ft} . \ldots \ldots \ldots \ldots \ldots \ldots \ldots \ldots \ldots . \ldots \ldots$

3 to $31 / 2 \mathrm{ft} \ldots \ldots \ldots \ldots \ldots \ldots \ldots \ldots \ldots \ldots \ldots \ldots \ldots$

Spiraea Billardi. Pink Summer Spiraea.

Pink flowers in terminal spikes during July and August. $5 \mathrm{ft}$.

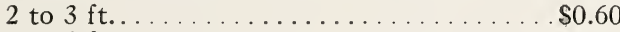

3 to $4 \mathrm{ft}$.

\section{Spiraea Bumalda.}

Dwarf rose-pink flowers, July to September. $21 / 2 \mathrm{ft}$.

12 to 18 in..

$\$ 0.70$

18 to 24 in.

Spiraea Callosa Alba.

White flowers in clusters all summer. A dwarf shrub of compact symmetrical form. Refined foliage. $3 \mathrm{ft}$.

12 to $18 \mathrm{in.}$

$\$ 0.70$

18 to 24 in.

\section{Spiraea Collosa Rosea.}

Rose colored flowers, July and August. $31 / 2 \mathrm{ft}$.

12 to 18 in..

18 to 24 in.

24 to 30 in.

\section{Spiraea Douglasi.}

Rose-pink flowers in spikes, July and August. $6 \mathrm{ft}$.



Bridal Wreath-the most popular shrub

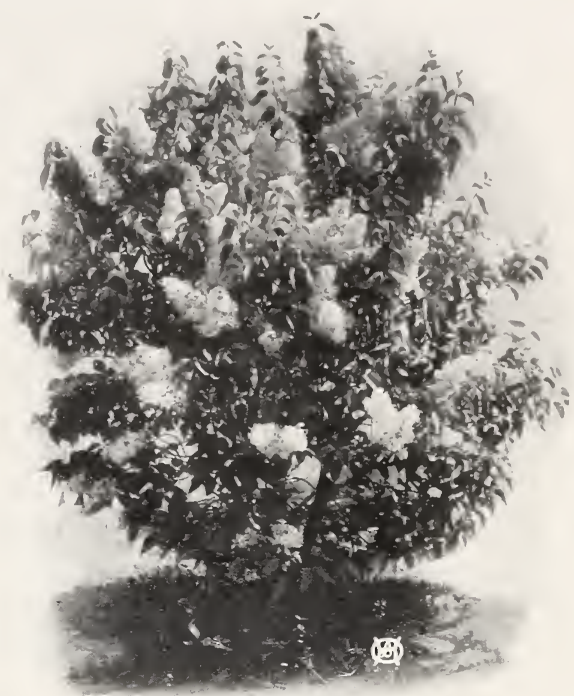

Plant Lilacs for color and fragrance

Spiraea Froebeli.

Each

Crimson flowers in flat clusters during July and

August. An excellent dwarf border shrub. Very hardy. $3 \mathrm{ft}$.

18 to 24 in..

$\$ 0.80$

2 to $3 \mathrm{ft}$.

Spiraea Opulifolia. Ninebark.

Tall, vigorous shrub with heavy foliage and many small clusters of white flowers. Well suited for planting as a screen or background. $8 \mathrm{ft}$.

2 to $3 \mathrm{ft}$.

S0.60

3 to $4 \mathrm{ft}$.

.80

4 to $5 \mathrm{ft}$.

1.25

Specimen shrubs

$\$ 2.00$ to 3.00

Spiraea Opulifolia Aurea. Golden Spiraea.

An ornamental, golden-leaved shrub. $6 \mathrm{ft}$.

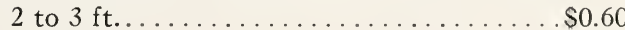

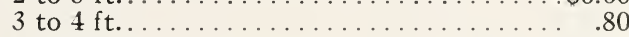

4 to $5 \mathrm{ft}$.............................. 1.25

Specimen shrubs

$\$ 2.50$ to 4.00

Spiraea Prunifolia.

White flowers in May. Needs protection. $5 \mathrm{ft}$. 3 to $4 \mathrm{ft}$.

$\$ 1.25$

Spiraea Sorbifolia. Plume Spiraea.

Foliage resembling a Mountain Ash. Long, spikes of white flowers in July. Begins growth very early. Stands either full sun or partial shade. $5 \mathrm{ft}$.

2 to $3 \mathrm{ft}$. . . .

3 to $4 \mathrm{ft}$.

Spiraea Thunbergii. Snow Garland.

Graceful slender branches. Light feathery foliage. Abundant white flowers in May. One of the earliest shrubs to bloom in the spring. $3 \mathrm{ft}$.



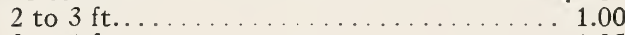

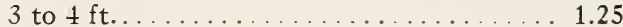


Spiraea Van Houttei. Bridal Wreath.

The most admired of all shrubs. A round, graceful bush with arching branches. White flowers in masses in late May. The most popular and most planted of all shrubs. Will grow in almost any location. Very hardy. 5 to $6 \mathrm{ft}$. Each 18 to 24 in. . $\$ 0.50$

2 to $3 \mathrm{ft}$. . .

3 to $4 \mathrm{ft}$.

4 to $5 \mathrm{ft}$. .

Specimen shrubs

.80

1.25

Sumac, Fern-Leaved (Rhus glabra laciniata).

Very desirable small shrub with deeply-cut leaves. 3 to $4 \mathrm{ft}$.

18 to 24 in..

$\$ 0.90$

2 to $3 \mathrm{ft}$.

Sumac, Fragrant (Rhus canadensis).

A compact-growing shrub with thick, fragrant leaves. Crimson autumn color. $3 \frac{1}{2} \mathrm{ft}$.

2 to $3 \mathrm{ft}$.

$\$ 0.90$

3 to $4 \mathrm{ft}$.

\section{Sumac, Smooth (Rhus glabra).}

Large growing shrub with special value for its gorgeous fall coloration. $10 \mathrm{ft}$.

2 to $3 \mathrm{ft}$.

$\$ 0.60$

3 to $4 \mathrm{ft}$.

4 to $5 \mathrm{ft}$.

1.25

Sumac, Tall Cut-Leaved (Rhus typhina).

Delicate, deeply-cut leaves that show crimson in the fall. Splendid to add variety to heavier shrub masses. 8 to $10 \mathrm{ft}$.

2 to $3 \mathrm{ft}$.

3 to $4 \mathrm{ft}$.

.90

Tamarix Pentandra. Summer Tamarix.

Feathery, bluish-gray foliage; with carmine-pink flowers in long loose terminal clusters. June and July. The delicate foliage is often used in flower bouquets. The appearance is so unlike other shrubs as to always attract attention. Does best in a protected spot. $6 \mathrm{ft}$.

2 to $3 \mathrm{ft}$.

3 to $4 \mathrm{ft}$.

$\$ 0.80$

Specimen shrubs

$\$ 2.00$ to 3.00

Thorn Apple (Crataegus).

A hardy Hawthorn. White flowers. Red fruits. 10 to $12 \mathrm{ft}$.

3 to $4 \mathrm{ft}$.

$\$ 1.00$

4 to $5 \mathrm{ft}$.

1.50

Viburnum, Arrow Wood (V. Dentatum).

Glossy-green leaves; white flowers in June. Berries are crimson turning to blue. Stands partíal shade. $8 \mathrm{ft}$.

2 to $3 \mathrm{ft}$.

$\$ 0.90$

3 to $4 \mathrm{ft}$.

1.25

Viburnum, High-bush Granberry (V. opulus). White flowers in spring followed by brilliant red, edible berries. Very hardy', A large growing shrub always ornamental but especially so during the fall because of its bright berry clusters and autumn foliage coloration. $8 \mathrm{ft}$.

2 to $3 \mathrm{ft}$.

$\$ 0.90$

3 to $4 \mathrm{ft}$.

1.25

4 to $5 \mathrm{ft}$.
Viburnum, Sheepberry ( $V$. lentagó).

Bright green leaves; \&fragrant creamy-white flowers. Large dark bluxe berries. $10 \mathrm{ft}$. Each

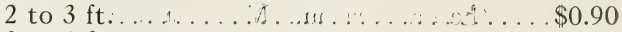
3 to $4 \mathrm{ft} \ldots \ldots \ldots \ldots \ldots \ldots \ldots \ldots$

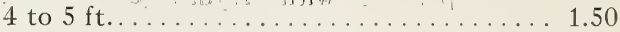

Viburnum, Snowball (V. opulus sterile).

The hardy, old-fashioned Snowball bush. Globular white flowers. $7 \mathrm{ft}$.

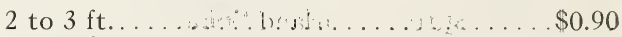

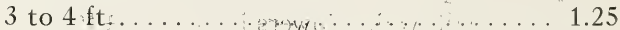

Viburnum, Wayfaring Tree ( $V$. lantana).

Large, white flower clusters in May. Red berries later turning black. "Splendid foliage. $10 \mathrm{ft}$.

2 to $3 \mathrm{ft}$.

$\$ 0.90$

3 to $4 \mathrm{ft}$.

\section{Weigela Desbois.}

Trumpet shaped, rose-colored flowers. Spreading growth. Needs protection. $4 \mathrm{ft}$.

2 to $3 \mathrm{ft}$.

Weigela, Eva Rathke.

Large, crimson, trumpet-shaped flowers. Free blooming. Needs protection. $4 \mathrm{ft}$ :

18 to $24 \mathrm{in}$.

2 to $3 \mathrm{ft}$. .

Weigela Rosea.

Pink, bell-shaped flowers in profusion. Good foliage. Needs protection. $5 \mathrm{ft}$.

18 to $24 \mathrm{in.}$

2 to $3 \mathrm{ft}$.

$\$ 0.80$

3 to $4 \mathrm{ft}$.

Weigela, Variegated.

Green leaves marked with white. Pink flowers. Needs protection. 3 to $4 \mathrm{ft}$.

18 to 24 in.

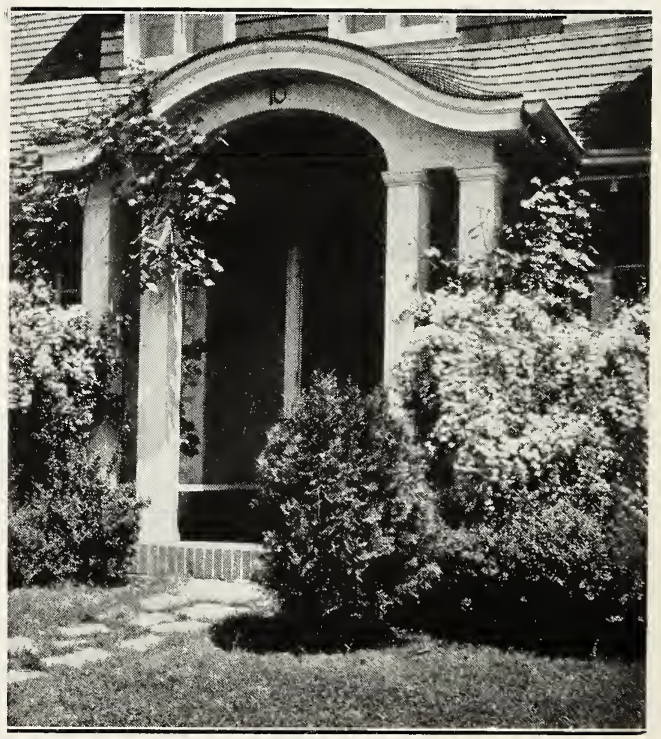

A pleasing doob-yard planting 


\section{TO HELP YOU IN YOUR SHRUB PLANTINGS}

\section{SHRUBS FOR PARTIAL SHADE}

Dogwood, in variety.

Page

Currant, yellow flowering .............. 10

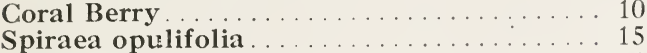

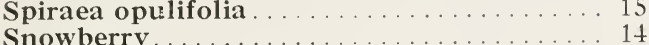

Honeysuckle, in variety............. 12

Hydrangea, Snowball ................... 12

Elder, in variety..................... 11

Philadelphus, in variety............... 13 \& 14

Viburnum, in variety.................. 16

Barberry. . . . . . . . . . . . . . . . . 10

\section{SHRUBS FOR HOUSE FOUNDATION}

\section{Medium Height Varieties}

Spiraea Van Houttei

Hydrangea, in variety.

Snowberry

Coral Berry

Philadelphus Lemoinei.

Cotoneaster acutifolia.

Elder, cut leaf.

Currant, yellow flowering

Almond, flowering.

Spiraea, tall varieties.

\section{Dwarf or Border Varieties}

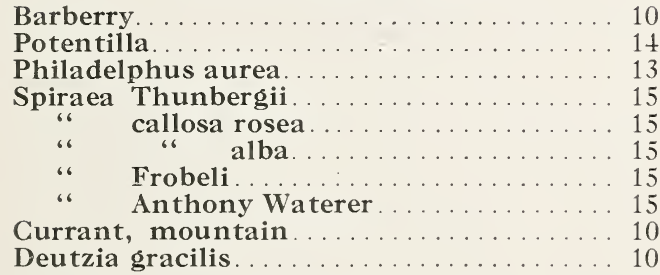

\section{SHRUBS FOR SCREEN PLANTING \\ (Bushy, Tall-Growing and Very Hardy)}

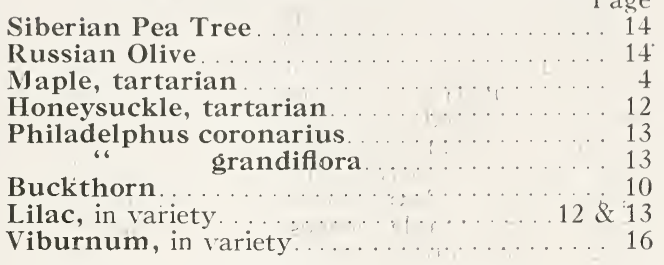

SHRUBS WITH BRIGHT AUTUMN COLOR

Barberry ........................ 10

Chokeberry....................... 10

Euonymus........... 11

Sumac, in variety ............. 16

Viburnum, in variety. . . . . . . . . . . 16

Maple, tartarian ................ 4

\section{BE RRIED SHRUBS FOR BIRD FOOD}

Chokeberry .................... 10

Barberry ......................... 10

Dogwood, Red Osier.................... 11

“ Red twigged.................. 11

، Gray bark..................... 11

Honeysuckle, Morrow's ... . . . . . . . . . . . . 12

" tartarica ................... 12

Rosa lucida ...................... 32

" acicularis .................... 32

“ rugosa........................ $1+\& 31$

“ setigera........................... 32

“ wichuraiana ..................... 32

Elder, black fruited..................... 11

" red berried....................... 11

Viburnum dentatum ................. 16

\section{How to Prune Shrubs}

Unless located in a sheared hedge or in some very formal planting scheme, the flowering shrubs should be allowed to retain their natural shape and development. Continual pruning into globes and restrained outlines cuts away all the plant's natural beauty and individuality. The only good reason for pruning other than the prompt removal of dead wood is to keep the shrubs from spreading too wide and growing too tall for their positions. This corrective pruning is best done by cutting out the oldest and heaviest branches directly at the ground-line and doing a little top shortening if required. The early blooring varieties such as Bridal Wreath and Lilacs are better trimmed after their blossoming period, if one wants to enjoy that season's flowers. The later blooming varieties such as Hydrangeas, and Spiraea Anthony Waterer can be trimmed heavily in early spring with no loss of that year's blossoms, and with positive benefit to the growth.

\section{COMPLETE LANDSCAPE SERVICE}

THE PLANTS. We grow in our nurseries those plant varieties that are hardy and suitable for use in this northern section. Our plants have gained a reputation for high quality and thriftiness.

THE PLANS. Men who know how to produce landscape results, through years of experience, and training, are here to advise with you in all your planting problems. With their helpful advice your gardening work - whether modest or extensive - can be carried out in the most practical and economical way.

THE COMPLETE SERVICE-Hardy Plants and Experienced Advice-means satisfaction for you. You secure the maximum in results at the minimum expense of time and money. Tell us of your plans and we will offer suggestions. 


\section{HARDY HEDGES For a Living Wall of Green}

There is nothing quite so effective for the boundaries of a lawn or property division as a hedge. It does not decay, nor does it require paint, but grows more beautiful, more effective and consequently more valuable, year after year. A good hedge is an asset to any piece of property. The first cost of installing a hedge is its only cost, so that, from an economical standpoint, it is less expensive than a fence. Dense, impenetrable hedges may be had if Buckthorn or Cotoneaster is used.

PLANTING HEDGES. A trench should be dug where the planting is to be done, excavated to a depth of a foot and 18 inches wide. Such a trench gives an even line to guide the planter. Discard any soil of poor quality and use surface loam. Varieties such as Japanese Bar-
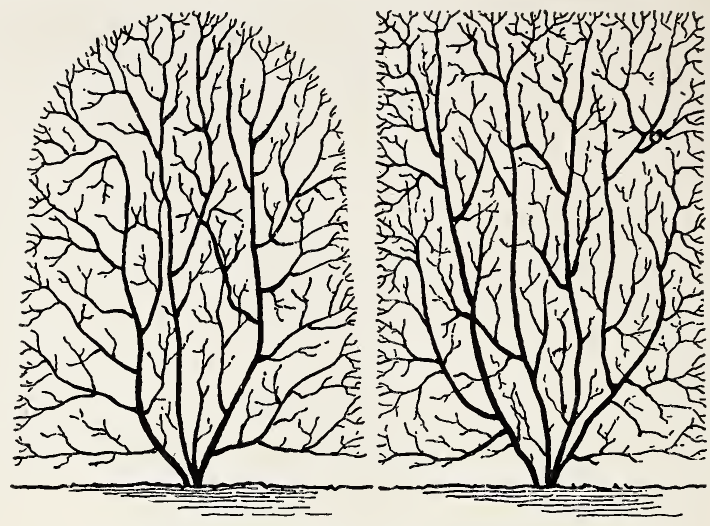

The Hedges can be trimmed to either a round or a square top outline berry, Buckthorn and Cotoneaster, or those that are to be kept closely cut, should be spaced a foot apart in the row. In using Bridal Wreath or other open-growing varieties which are not to be kept sheared, a spacing of 2 to 3 feet is proper. After planting, cut off at least one-third of the top of the plants to insure good lateral growth. Water thoroughly.

For more complete descriptions see our book "CREATING YOUR LANDSCAPE"—sent on request. Information as to growth, selection or planting of hedges will be cheerfully given by our Landscape Department.

Barberry, Thunberg's (Berberis Thunbergii).

Very satisfactory for a low hedge of close growth.

Can be trimmed or allowed to grow naturally.

Bears attractive red berries in the fall.

12 to 18 in.

18 to 24 in.

24 to $30 \mathrm{in.}$

Buckthorn (Rhamus catharticus).

An ornamental plant of great hardiness that makes a dense hedge. Can be kept trimmed to any desired height or outline. Always satisfactory.

18 to 24 in................. $\$ 2.50 \$ 18.00$

2 to $3 \mathrm{ft} \ldots \ldots \ldots \ldots \ldots \ldots \ldots \ldots \ldots \ldots .3 .00 \quad 22.00$



4 to $5 \mathrm{ft} \ldots \ldots \ldots \ldots \ldots \ldots \ldots \ldots \ldots .5 .00 \quad 40.00$

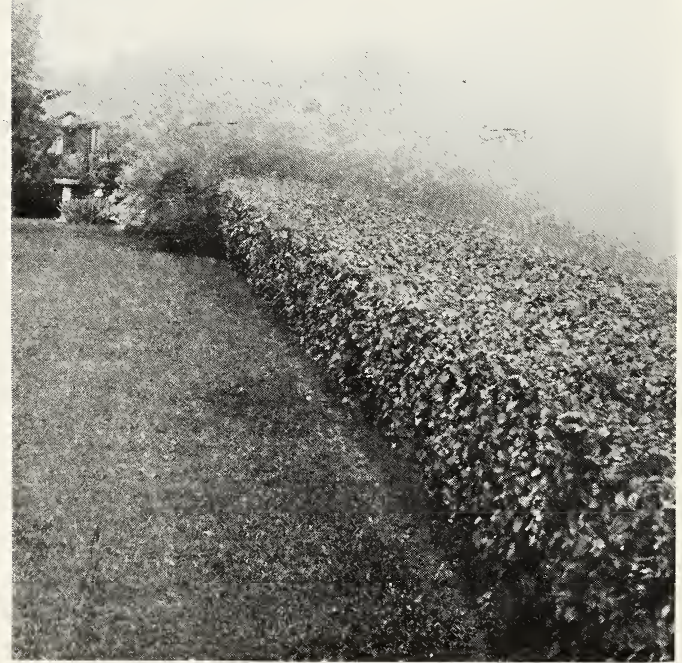

Euck thorn makes a close-growing, dependable hedge

\section{Cotoneaster Acutifolia (Quinceberry).}

A dense-growing shrub with dark-green, glossy, oval leaves. A splendid hedge plant for the Northwest. Perfectly hardy.

18 to 24 in.

Per 10 Per 100

2 to $3 \mathrm{ft}$.

$\$ 3.00 \$ 27.00$

3 to $4 \mathrm{ft}$..

32.00

$5.00 \quad 37.00$

\section{Honeysuckle (Lonicera Tatarica).}

In addition to great hardiness the Honeysuckles have attractive flowers and berries. Suitable where a tall untrimmed hedge is wanted.

2 to $3 \mathrm{ft}$.

$\$ 5.00 \$ 40.00$

3 to $4 \mathrm{ft}$..

$7.00 \quad 60.00$

\section{Rosa Rugosa (Japanese Rose).}

Desirable for an open, untrimmed division hedge. Foliage and bright flowers are highly ornamental.

$\$ 8$ to 24 in., 2-yr. plants

$\$ 6.00 \$ 50.00$

\section{Russian Olive (Elaeagnus argentea).}

For a tall, heavy hedge the Russian Olive is unequalled. Leaves, silvery-white beneath, are very ornamental. Will stand the most rigorous climatic conditions.
2 to $3 \mathrm{ft}$.
$\$ 5.00 \$ 40.00$
3 to $4 \mathrm{ft}$.
$6.00 \quad 50.00$
4 to $5 \mathrm{ft}$.
$7.00 \quad 60.00$

\section{Spiraea Van Houttei (Bridal Wreath).}

The most satisfactory of hardy shrubs for use as a flowering hedge. Plant only where close trimming is not required. 


\section{CLIMBING VINES}

\section{Enjoyed for Both Foliage and Flowers}

Climbing Vines are just as necessary to the beauty of home-grounds as shrubs, trees, or grass; they have their important part in the planting of every place.

Around new buildings, they give shade quickly and are very cooling and cheerful. For verandas or trellises, there is nothing that adds more charm than a proper planting of vines.

Vines are often used for covering stone walls, rocky banks, and steep slopes, where the foliage as well as the fragrance from the flowers is pleasing. Innumerable uses for vines will suggest themselves when improving a property.

For more complete descriptions see our book, "CREATING YOUR LANDSCAPE." A copy will be sent on request.

\section{Bittersweet (Celastrus scandens).}

Hardy, native climber. Red berries.

Each

2 yrs.

3 yrs.

Extra strong plants

Boston Ivy (Ampelopsis Veitchii).

Not altogether hardy in Minnesota.

2 yrs.

3 yrs.

Glematis Coccinea (Scarlet Clematis).

2 yrs., strong potted plants.

Clematis Henryi. Single, creamy-white flowers.

2 yrs., strong potted plants.

Clematis Jackmani. Violet purple. The most popular and the hardiest of the blue flowering Clematis.

2 yrs., strong potted plants. . . . . . . . $\$ 1.25$

3 yrs., strong potted plants. . . . . . . . . 2.00

Clematis, Mme. Edouard Andre. Velvety red. 2 yrs., strong potted plants. . . . . . . \$1.25

Clematis Paniculata (Sweet Autumn Clematis). Rapid growth. Fragrant, white flowers in August.

2 yrs., strong potted plants. . . . . . . . \$1.00

3 yrs., strong potted plants. . . . . . . . . 1.50

Clematis Virginiana (Virgin's Bower). Native, hardy Clematis. Greenish-white flowers.

2 yrs., strong. . . . . . . . . . . . . . . . \$ 80.80 Potted plants. . . . . . . . . . . . 1.25

Dutchman's Pipe (Aristolochia Sipho). Large, heart-shaped leaves.

2 yrs., strong...................\$1.25

3 yrs., strong. . . . . . . . . . . . . . . . 1.50

Engelmann's Ivy (Ampelopsis Engelmanni). This is the only Ivy that is perfectly hardy in Minnesota, and that will cling to brick, stone or plaster.

2 yrs..

. $\$ 0.60$

3 yrs. .

80

Extra-strong plants

1.00

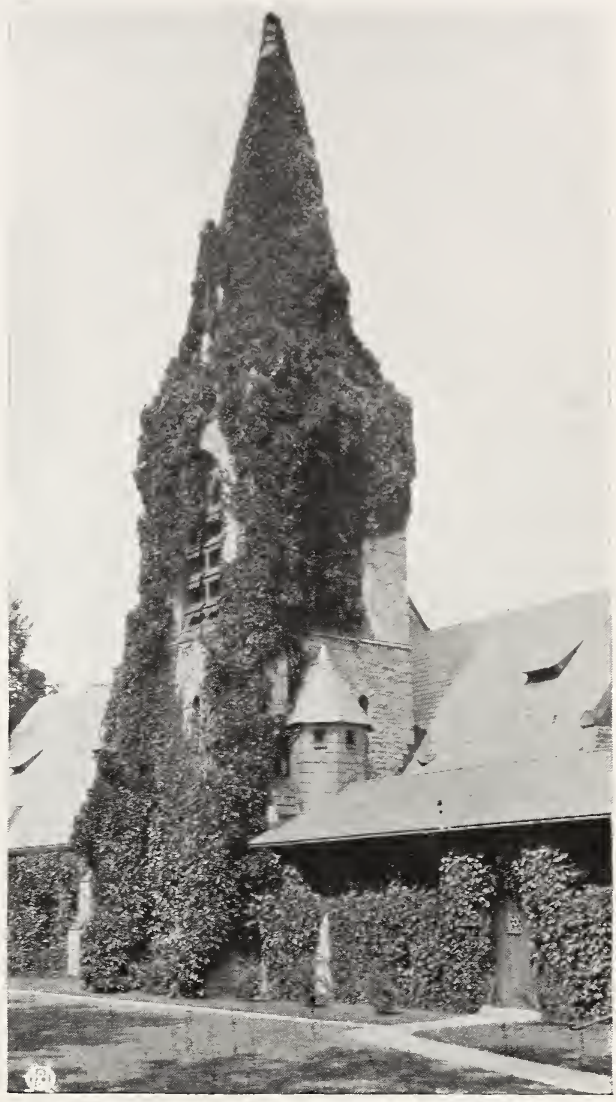

The Englemann's Ivy throws a mantle of living green over the tower of St. Clement's Church, Saint Paul

Grape, Beta. Desirable for fruit or foliage.

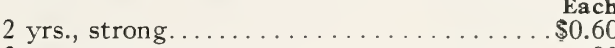

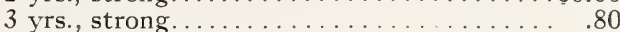

Extra strong plants............... 1.00

Grapes, Hardy Wild.

2 yrs., strong....................\$0.60

3 yrs., strong. . . . . . . . . . . . . . 80

Honeysuckle, Hall's Japan (Lonicera Halliana). 2 yrs., strong...................\$0.70

Honeysuckle, Scarlet Trumpet (Lonicera sempervirens). Scarlet, tubular flowers.

2 yrs., strong. . . . . . . . . . . . . . \$ $\$ .70$

3 yrs., strong ................... 90

Matrimony Vine (Lycium Chinensis). For banks and slopes. Brilliant red berries in fall.

2 yrs........................ $\$ 0.60$ 3 yrs........................ 80

Extra strong. . . . . . . . . . . . . 1.00

Virginia Creeper (Ampelopsis Quinquefolia).

2 yrs........................\$\$ $\$$

3 yrs.

Wisteria. Purple. For protected places only. 2 yrs., strong...................\$1.00 3 yrs., strong 


\section{THE HARDY GARDEN FLOWERS}

In this table is indicated the height of growth and color and season of bloom of the more popular flowering Perennials. The data has been complied from actual Minnesota gardens.

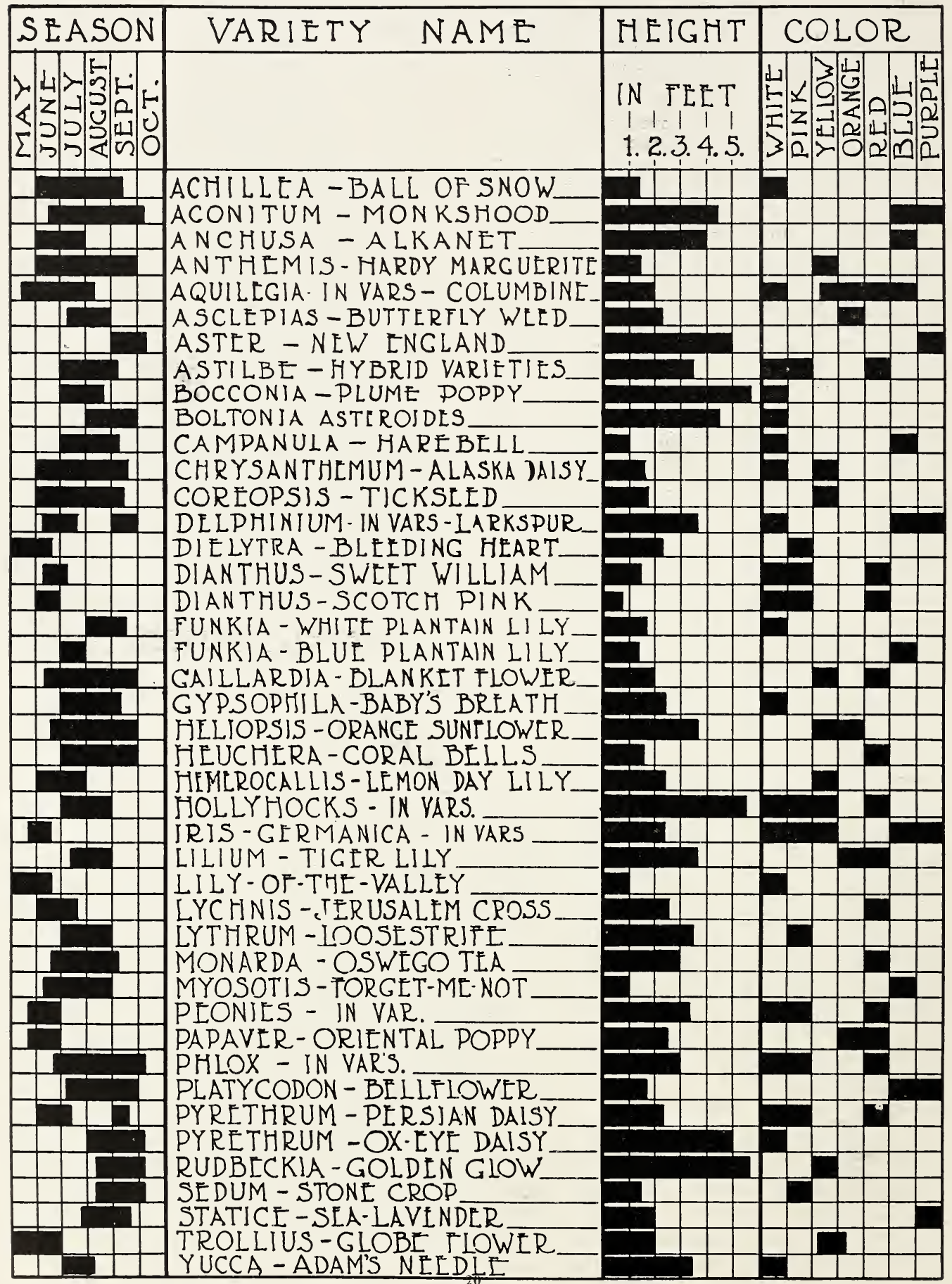




\section{PERENNIALS HARDY GARDEN FLOWERS}

The Perennials persist over winter and renew their growth with increased vigor in the spring. Their first cost is small, so that one can enjoy a good assortment at a modest outlay. Then you consider their tendency to be permanent, giving flowers year after year with only minimum care, then their really small expense yet exceedingly great value is apparent.

Soil and Planting. Perennials are best arranged in beds or borders with varieties selected so that there will be some in bloom at all times. The time of blooming is given in the descriptions. The soil should be well worked up and fertilized if necessary. Surface cultivation of the ground between the plants should be practiced. A location free of tree roots and dense shade is desirable.

Note. The development of perennials after planting is dependent upon soil, moisture, location and many such factors over which we

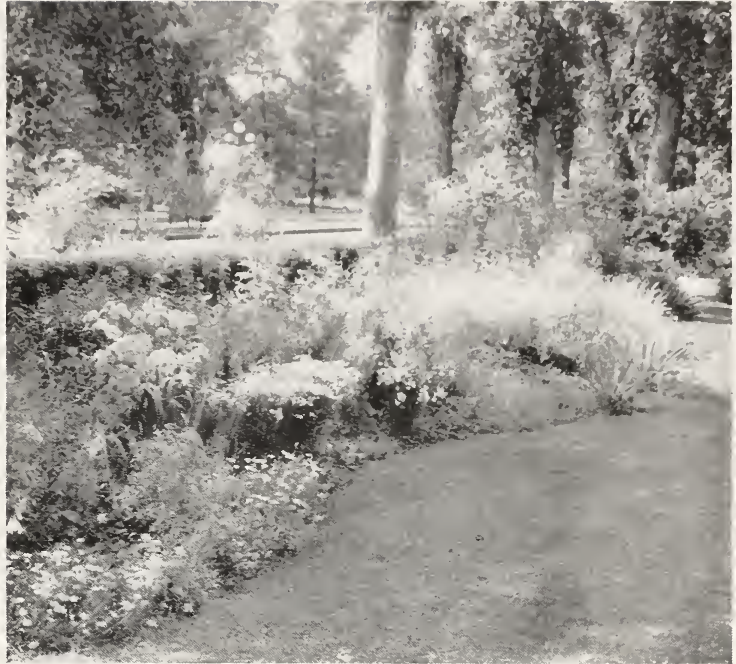

There are always flowers to enjoy and cut in the perennial border Mr. Fred Benjamin, White Bear have no control. Our customers can feel sure of receiving from our nurseries the best grade of stock, properly handled and packed, but should not expect us, nor do we agree, to assume responsibility as to the outcome of their plantings or to make replacements without charge.

Quantity Rate. Ten or more plants of a variety will be supplied at $5 c$ less per plant. Example: Plants priced at $35 \mathrm{c}$ each are $\$ 3.00$ for ten.

For additional descriptions of Perennials see our large catalogue "CREATING YOLR LANDSCAPE' -sent on request.

Achillea, Boule de Neige. Ball of Snow: Thite flowers of full and perfect form. $1 \frac{1}{2} \mathrm{ft}$. June to Sept. 35 cts.; 2 yr., 50 cts.

Achillea Millefolium Roseum. Rosy Milfoil. Pink flowers in compact heads. $2 \mathrm{ft}$. June to Sept. 35 cts. 2 yr., 50 cts.

Achillea, Perry's White. Pure white flowers of broad overlapping petals. Blooms June to Sept. $11 / 2 \mathrm{ft}$. Fine cut flower. $35 \mathrm{cts}$; $2 \mathrm{yr}$., $50 \mathrm{cts}$.

Aconitum Fischeri. Late Monkshood. Strong spikes of dark blue helmet shaped flowers. $3 \mathrm{ft}$. October. 40 cts.; 2 yr., 60 cts.

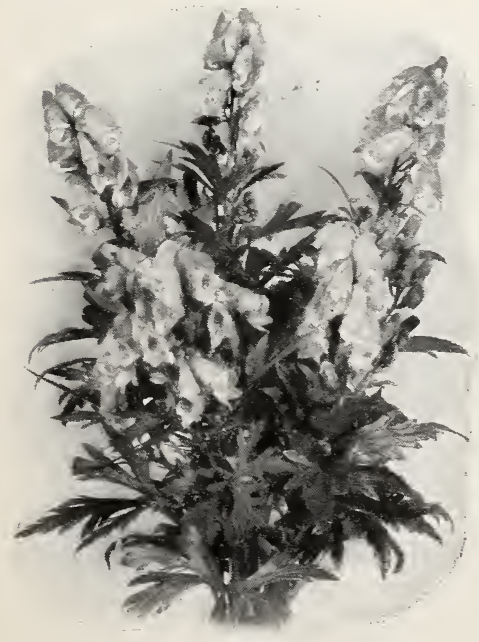

Helmet-shaped flowers of Aconitum 2 yr., 50 cts. 2 yr., 50 cts. 2 yr., 50 cts.
Aconitum Napellus. Monkshood. Loose spikes, bright blue flowers, attractive lustrous green leares. $t \mathrm{ft}$. Sept. $40 \mathrm{cts}$; 2 yr., $60 \mathrm{cts}$.

Alaska Daisy. 30 cts.; 2 yr., 50 cts. (See Chrysanthemum Maximum)

Alyssum Saxatile Compactum. Golden Tuft Masses of yellow flowers in early spring. For rockery or border. 12 inches. 30 cts.; 2 yr., 50 cts.

Anchusa Italica, Dropmore. Alkanet. Gentianblue flowers in June and July. Four to five feet. Large heavy leaves. 40 cts.: 2 yr., 60 cts.

Anthemis Tinctoria Kelwayi. Hardy Marguerite. Daisy-like flowers of golden-yellow. $11 / 2 \mathrm{ft}$. June to Oct. Delicate foliage. 30 , cts.; 2 yr., 50 cts.

Aquilegia Canadensis. Canada Columbine. Flowers red and yellow. Medium short spurs. $2 \mathrm{ft}$. June to Aug. 35 cts.;

Aquilegia Chrysantha. Golden Columbine. Yellow flowers with long spurs. $2 \mathrm{ft}$. June to Aug. $35 \mathrm{cts}$. 2 yr.. $50 \mathrm{cts}$.

Aquilegia Helenae. Blue Columbine. $1 \frac{1}{2} \mathrm{ft}$. June to Aug. 35 cts.; 2 vr., 50 cts.

Aquilegia Hybrids. Long-spurred flowers in a variety of beautiful colors. 35 cts.; 2 yr., 50 cts.

Arabis Alpina. Rock Cress. Dwarf plant, compact and spreading, covered with white flowers. 6 in. April and May. 35 cts.;

Armeria Formosa. Sea Pink. Dwarf border or rockery plant. Pink flowers on wiry stems. 9 in. All season bloom. 35 cts.

Armeria Laucheana. Rosy crimson flowers on wiry stems. 9 in. 35 cts.; 2 yr., 50 cts.

Artemisia Lactiflora. Mountain Fringe. Large branching panicles of sweetly scented, creamy white flowers. 3 to $4 \mathrm{ft}$. Aug. to Sept. 40 cts, ; 2 yr., 60 cts.

Aster Novae-Angliae. New England Aster (Michaelmas Daisy). Hardy purple Aster. \pm to $5 \mathrm{ft}$. Sept. and Oct. 35 cts. ; 2 yr., 50 cts 


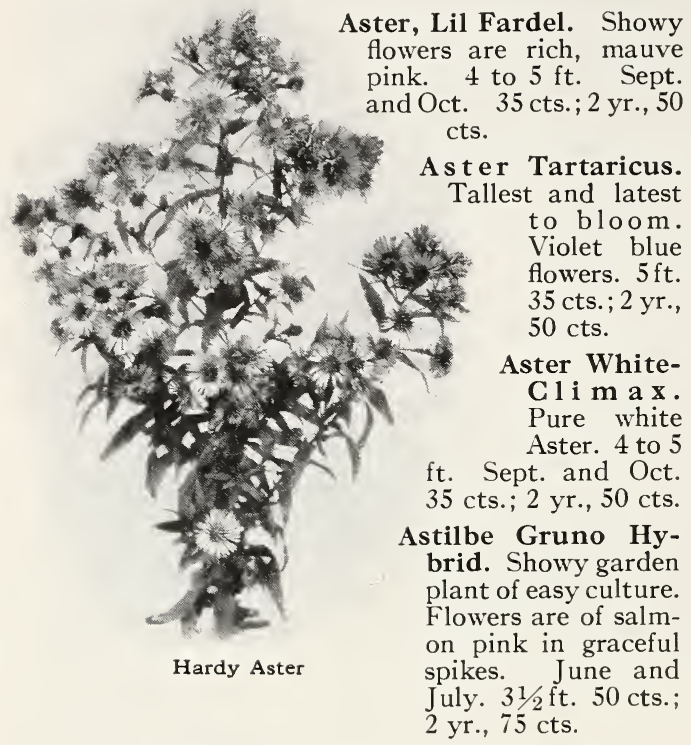

Astilbe Japonica (Spiraea Japonica). Heavy spikes of white, feathery flowers in June and July. Showy in the garden. Good for cutting. $21 / 2 \mathrm{ft}$. 75 cts.; 2 yr., \$1.00.

Astilbe Salland. Red stems and red flowers. $60 \mathrm{cts}$.

Baptisia Australis. False Indigo. Spikes of dark blue flowers in June and July. Likes sunlight and dry soils. $3 \mathrm{ft}$. 35 cts.; 2 yr., 50 cts.

Bleeding Heart (Dicentra Spectabilis). Rosecrimson heart-shaped flowers in drooping racemes. The old favorite garden flower. 18 inches. April and May. Partial shade. 60 cts.; 2 yr., $\$ 1.00$.

Bocconia Cordata. Plume Poppy. Tall growing perennial fine for background. $6 \mathrm{ft}$. Creamy white plumy flowers in August. 35 cts.; 2 yr., $50 \mathrm{cts}$.

Boltonia Asteroides. False Starwort. Pure white, Aster-like flowers in profusion. Excellent cut flowers. 4 to $5 \mathrm{ft}$. Aug. and Sept. 35 cts.; 2 yr., 50 cts.

Boltonia Latisquama. A variety of False Starwort with pinkish lavender flowers. 35 cts.; 2 yr., 50 cts.

Campanula Carpatica. Carpathian Harebell. Dwarf habit and compact growth. Bell-shaped, light blue flowers in July and August. 8 to 10 ins., 35 cts.; 2 yr., 50 cts.

Campanula Carpatica Alba. White Harebell. A whiteflowering form of the above. 35 cts.; 2 yr., 50 cts.

Campanula Calycanthema. Cup-and-Saucer Bellflower. A biennial. Blooms July and Aug. $3 \mathrm{ft}$. Colors mixed in blue, rose and white. 35 cts.; 2 yr., 50 cts.

Campanula Glomerata. Clustered Bellflower. Dense tuft of dark green foliage with globular dark-blue flowers. 18 ins. June and July. 40 cts.; 2 yr., 60 cts.

Campanula Medium. Canterbury Bells. A biennial. Large bell flowers of rose, blue and white. July. $3 \mathrm{ft}$. 35 cts.; 2 yr., 50 cts.

Campanula Persicifolia. Peach-leaved Bellflower. Cupshaped blue flowers during June and July. $2 \mathrm{ft} .35$ cts.; 2 yr., 50 cts.

Campanula Pyramidalis. Chimney Bellflower. White and porcelain-blue flowers in August on tall pyramidal plant. 4 to $5 \mathrm{ft}$. $35 \mathrm{cts}$; 2 yr., 50 cts.
Centaurea Montana. Perennial Cornflower. Violet-blue flowers resembling cornflowers. $11 / 2$ ft. July to Sept. 35 cts.; 2 yr., 50 cts.

Chrysanthemum Maximum. Alaska Daisy. An improved Shasta Daisy that blooms freely all summer. White flowers with yellow center. Height 12 to 15 ins. 30 cts.; 2 yr., 50 cts.

Chrysanthemum Maximum. Moonpenny Daisy. White Daisy of moderate size. $3 \mathrm{ft}$. July to Oct. 30 cts.; 2 yr., 50 cts.

Clematis Davidiana. A bush Clematis with pale blue flowers in small clusters. Fragrant. 3 to 4 ft. August and Sept. 60 cts.; 2 yr., $\$ 1.00$.

Clematis Recta. Shrubby growth to $3 \mathrm{ft}$. Flowers are white in showy clusters on long stems. June and July. 60 cts.; 2 yr., $\$ 1.00$.

Coreopsis Lanceolata Grandiflora. Tickseed. Golden yellow flowers on long graceful stems from June until frost. Fine for cutting. Narrow light green leaves. $2 \mathrm{ft}$. $30 \mathrm{cts}$; 2 yr., 50 cts.

Day Lily. See Hemerocallis.

Delphinium Chinense. Slender Larkspur. Heads of bright blue flowers in open sprays from June until frost. Finely cut, fern-like foliage. $3 \mathrm{ft}$. 35 cts.; 2 yr., 50 cts.

Delphinium Chinense Alba. White flowering form of the Slender Larkspur. 35 cts.; 2 yr., 50 cts.

Delphinium Belladonna. Clear, turquoise blue flowers with long blooming habit. 3 to $4 \mathrm{ft}$. 35 cts.; 2 yr., 50 cts.

Delphinium Bellamosa. A dark blue Larkspur of free-blooming habit. 3 to $4 \mathrm{ft}$. 35 cts.; 2 yr., 50 cts.

Delphinium Hybrids. Large flowers of varied shades of blue in strong spikes. 35 cts.; 2 yr., $50 \mathrm{cts}$.

Dianthus Barbatus. Sweet IVilliam. Flowers in variations of red, white and rose colors. May to July. 18 ins. 30 cts.; 2 yr., 50 cts.

Dianthus Deltoides. Maiden Pink. A dwarf plant with rosy pink flowers from June to August. 9 ins. 30 cts.; 2 yr., 50 cts.

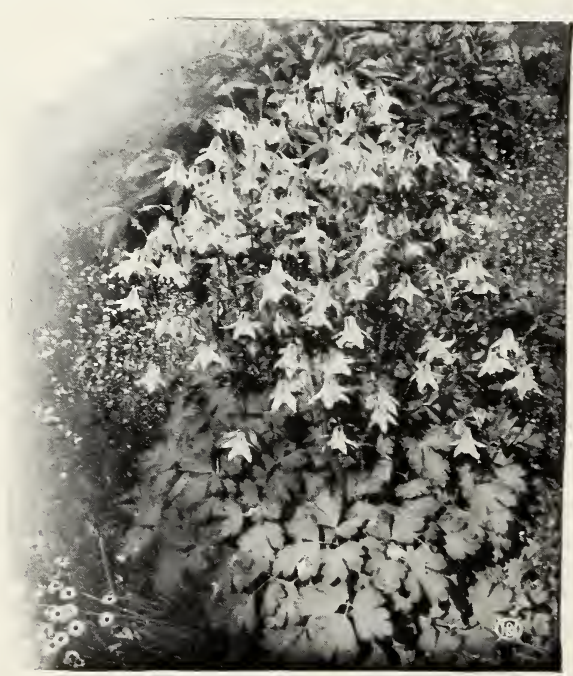

The Columbine's quaint flowers 
Dianthus Plumarius. Clove Pink. The fragrant white to scarlet flowers bloom in early summer. Grass-like leaves. 9 ins. 30 cts.; 2 yr., 50 cts.

Dianthus Semperflorens. Everblooming Pink. A small growing Pink, flowers of mixed colors, with a long season of bloom. 30 cts.; 2 yr., 50 cts.

Dictamnus Fraxinella. Gas Plant. Bushy growth with terminal clusters of white and rose-pink flowers in June and July. $2 \frac{1}{2} \mathrm{ft}$. $60 \mathrm{cts}$; 2 yr., $\$ 1.00$.

Dicentra Eximia. Plumy Bleeding Heart. Rosy-pink heartshaped flower in bloom from May through August. Delicate, finely-cut foliage. 9 to 12 inches. $35 \mathrm{cts}$; $2 \mathrm{yr}$., $50 \mathrm{cts}$.

Dicentra Spectabilis. Bleeding Heart. The favorite oldfashioned flower. $2 \frac{1}{2} \mathrm{ft}$. April and May. $60 \mathrm{cts}$; 2 yr., $\$ 1.00$.

Digitalis Gloxiniaeflora. Foxglove. A biennial. White, purple and rose blossoms in long flowering spikes. $4 \mathrm{ft}$. July. 35 cts.; 2 yr., 50 cts.

Echinops Ritro. Globe Thistle. Ball-shaped metallic-blue flowers; thistle-like foliage. $3 \mathrm{ft}$. July to Sept. $40 \mathrm{cts}$; 2 yr., 60 cts.

Ferns, Hardy. A collection of strong-growing, native varieties suitable for yard plantings. $40 \mathrm{cts}$; 2 yr., $60 \mathrm{cts}$.

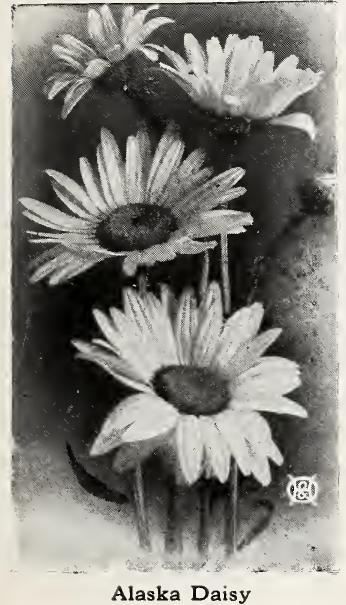

Alaska Daisy
Filipendula Palmata (Spiraea). Crimson Meadowsweet. Deep pink to carmine flowers in loose clusters. Purplish, leafy stems to $3 \mathrm{ft}$. June and July. 50 cts.; 2 yr., $70 \mathrm{cts}$.

Filipendula Ulmaria (Spiraea). Meadowsweet. Tufted, fernleaved plant. Masses of white flowers on 18-in. stems in June and July. 40 cts.; 2 yr., 60 cts.

Forget-Me-Not (Myosotis Scorpioides). Dainty blue flowers from May to Sept. 10 ins. 30 cts.; 2 yr., 50 cts.

Funkia (Hosta) Caerulea. Blue Plantain Lily. Drooping flowers of blue in July and August. 15 ins. Excellent border plant. Dark green, glossy foliage. Stands shade. 25 cts.; 2 yr., 40 cts.

Funkia Subcordata. White Plantain Lily. Fragrant, white, Lily-

like flowers in Aug. and Sept. Glossy foliage. 18 ins. 50 cts.; 2 yr., 75 cts.

Funkia Undulata Variegata. Broad, waxy foliage, beautifully variegated with white. Very attractive border plant. Blue flowers in July. 15 ins. Stands shade. 30 cts.; 2 yr., 40 cts.

Gaillardia Grandiflora. Blanket Flower. Rich red and crimson petals with broad border of yellow. A brilliant garden flower unsurpassed for cutting. June to Oct. $2 \mathrm{ft}$. 30 cts.; 2 yr., 50 cts.

Golden Glow. See Rudbeckia Laciniata. 30 cts.; 2 yr., 40 cts.

Gypsophila Paniculata. Baby's Breath. Cutflower. Tiny white blossoms cover the plant through July and August. 2 to $3 \mathrm{ft}$. $30 \mathrm{cts}$; 2 yr., 50 cts.

Gypsophila Paniculata fl. pl. Double Baby's Breath. Small double rosette-like flowers. White. "Much in demand for cut flower uses. $\$ 1.00$ each; extra strong, $\$ 1.50$ each.

Hardy Pinks. See Dianthus.

Helenium Autumnale Superbum. Sneezeweed. Golden yellow flowers in August and Sept. 4 to $5 \mathrm{ft}$. $35 \mathrm{cts}$; 2 yr., 50 cts.

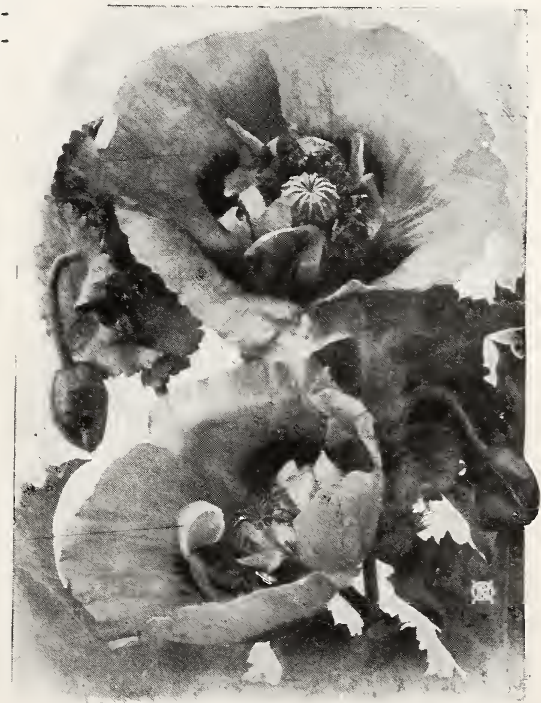

The Oriental Poppy is a gorgeous flower 


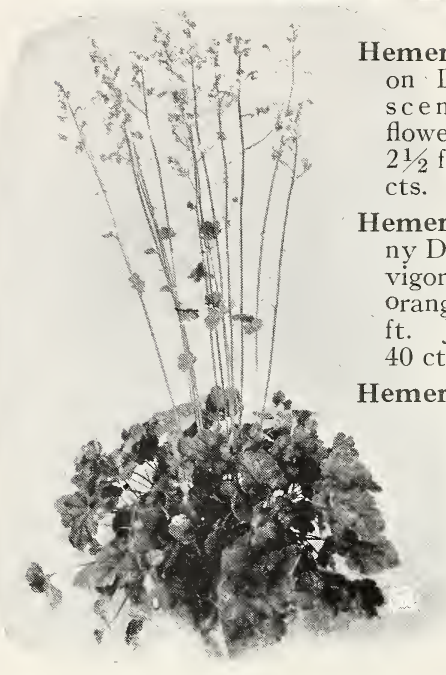

Heuchera or Coral Bells cts. rocallis Flava. Lemon Day Lily. Sweetly scented lemon-yellow flowers in Juneland July. $21 / 2 \mathrm{ft}$. 35 cts.; 2 yr., 50

Hemerocallis Fulva. Tawny Day Lily. Very hardy, vigorous perennial with orange colored Lilies. 3 ft. July. 30 cts.; 2 yr., 40 cts.

ocallis Midden dorfii. The earliest Day lily to bloom. June. Flowers are deep golden yellow. 2 to $3 \mathrm{ft}$. 35 cts.; 2 yr., 50 cts.

Hemeroca 11 is Thunberg i i. Late blooming variety. July and Aug. 3

yellow flowers. 35 cts.; 2 yr., 50 cts. f. Fragrant

Heuchera Pleu-de-Feu. Alum Root. Crimson flowers are borne in graceful sprays from middle to late summer. About the size of Lily-of-theValley bells. 18 ins. Evergreen leaves. $40 \mathrm{cts}$; 2 yr., 60 cts.

Heuchera Sanguinea. Coral Bells. Bright coralcrimson bells are held pendant from slender flower stems. 18 ins. July to Sept. Evergreen, geranium-like leaves. 40 cts.; 2 yr., 60 cts.

Hibiscus Crimson Eye. Rose Mallow. Large pure white flowers with deep crimson center. Aug. and Sept. $4 \mathrm{ft} .40 \mathrm{cts}$; 2 yr., 60 cts.

Hibiscus Mallow Marvels. Giant flowering varieties in crimson, pink and white. 4 to $5 \mathrm{ft}$. 40 cts, ; 2 yr., 60 cts.

Hollyhock, Althea. Allegheny Mammoth. Single flowers of delicately fringed petals. Mixed colors. 5 to $7 \mathrm{ft}$. July and Aug. 35 cts.; extra strong, $50 \mathrm{cts}$.

Hollyhock. Double Flowering.

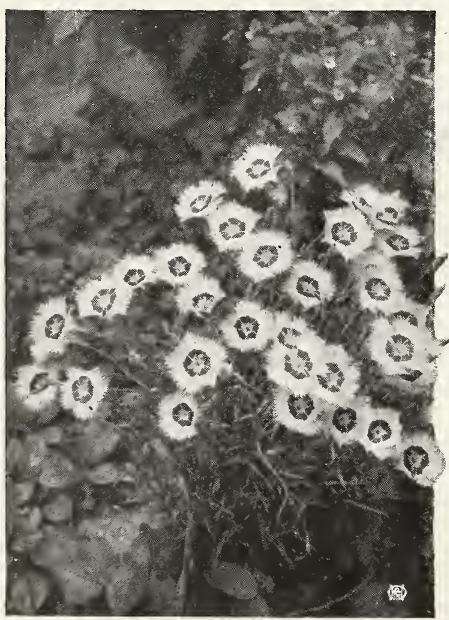

Yellow, white pink and red colors. July and Aug. 5 to $7 \mathrm{ft}$. 35 cts.; extra strong, $\quad 50$ cts.

Hollyhock. Single Flowering. Many prefer these single - flowered , varieties. Mixed colors. 35 cts.; extra strong, 50 cts.

Iris. Fleur-deLis. See list, Page 27.

Larkspur. See Delphinium.
Liatris Pycnostachya. Kansas Gay Featfrer. Tall, rocket-like spikes of rosy-purple flowers. $4 \mathrm{ft}$. Aug. and Sept. 35 cts.; 2 yr., 50 cts!

Lilium Auratum. Gold-banded Lily. Fragrant white flowers spotted crimson with central yellow band. Red anthers. $3 \mathrm{ft}$. July and Aug. Started and potted plants, 85 cts.

Lilium Elegans. Orange Lily. Very hardy variety producing orange-red flowers in great numbers. 18 ins. July. 35 cts.; 2 yr., 50 cts.

Lilium Regale. The Regal Lily. The acknowledged peer ot all lilies for Northern gardens. Recently introduced from N. W. China, and proving very hardy in Minnesota. The flowers are white with pink tinge on the outer side, with canary yellow shadings within the cup. Deliciously fragrant. 3 to $4 \mathrm{ft}$. Late July and early August. Large, dormant bulbs, 75 cts. each; started, potted plants, $\$ 1.00$ each.

Lilium Speciosum Album. Japanese. White flowers with re-curved petals. $2 \mathrm{ft}$. Aug. and Sept. Started, potted plants, 85 cts.

Lilium Speciosum Rubrum. A fragrant lily, under color white, shaded and spotted with crimson. 2 ft. Aug. and Sept. Started, potted plants, 85 cts.

Lilium Tigrinum F1. P1. Double Tiger Lily. A double flowering form of this well-known, hardy Lily. Orange-red spotted with black. Late July and August. $4 \mathrm{ft}$. Bulbs, 35 cts.; extra size, 50 cts.

Lily-of-the-Valley. Pure white, dainty bell-shaped flowers in May and June. Fragrant. 8 to 10 ins. Field clumps, 30 cts. ; extra heavy, $40 \mathrm{cts}$.

Linum Perenne. Blue Flax. Graceful foliage with delicate flowers of pearly blue. May to August. 18 ins. 35 cts.; 2 yr., 50 cts.

Lupinus Polyphyllus. Azure blue, pea-shaped flowers in long spikes. Late May and June. 3 to $4 \mathrm{ft}$. $40 \mathrm{cts}$; $2 \mathrm{yr}, 60 \mathrm{cts}$.

Lychnis Chalcedonica. Jerusalem Cross. Flowers of vermillion-scarlet in immense heads. $21 / 2$ ft. June to mid-July. 35 cts.; 2 yr., 50 cts.

Lythrum Roseum. Rose Loosestrife. Tall spikes of rose-colored flowers. July to Sept, 3 to $4 \mathrm{ft}$. 35 cts.; 2 yr., 50 cts.

Meadow Sweet (Filipendula). Pink to crimson flowers in feathery heads. June and July. Mixed colors. 50 cts.; 2 yr., 70 cts.

Mentha Spicata. Spearmint. Hardy garden mint. 30 cts.; 2 yr., 40 cts.

Monarda Didyma. Oswego Tea. Compact heads of bright red flowers. Arontatic foliage. June to Sept. 3 ft. 35 cts.; 2 yr., 50 cts. 
Monarda, Cambridge Scarlet. A variety of long blooming season with scarlet crimson flowers. 2 to $3 \mathrm{ft}$. $35 \mathrm{cts}$; 2 yr., $50 \mathrm{cts}$.

Myosotis. Scorpioides Forget-Me-Not. Delicate blue flowers on a dwarf border plant. May to Sept. 10 ins. 30 cts.; 2 yr., 50 cts.

Oenothera Missouriensis. Evening Primrose. Large golden-yellow poppy-like flowers from June to August. 12 inches. 35 cts.; 2 yr., 50 cts.

Pachysandra Terminalis. A valuable dwarf Evergreen perennial for ground cover planting. 6 to 9 ins. 30 cts.; 2 yr., 50 cts.

Penstemon Barbatus Torreyi. Beard Tongue. Tall spikes of brilliant scariet flowers. $31 / 2 \mathrm{ft}$. July. 35 cts.; 2 yr., 50 cts.

Peonies. See lists, pages 28 and 29.

Persian Daisy. See Pyrethrum Hybridum.

Phalaris Arundinacea. Ribbon Grass. A hardy grass with ornamental, variegated foliage. $30 \mathrm{cts}$; 2 yr., 50 cts.

Phlox. See list, page 30.

Physalis Franchetti. Chinese Lantern Plant. Brilliant orange colored seed-pods or "lanterns' in Sept. $2 \mathrm{ft} .30 \mathrm{cts}$; 2 yr., 50 cts.

Physostegia Virginica. False Dragon Head. Strong spikes of delicate pink flowers. July and Aug. 2 to $3 \mathrm{ft}$. 35 cts.; 2 yr., 50 cts.

Platycodon Grandiflorum. Balloon Flower. Star shaped blue flowers at the tip of each branch. Compact, bushy growth to 18 ins. June to Sept. 35 cts.; 2 yr., 50 cts.

Platycodon Grandiflorum Album. A white flowered variety of the above. 35 cts.; 2 yr., 50 cts.

Platycodon Grandiflorum Mariesi. A darker blue variety of smaller size. 12 ins. 35 cts.: 2 yr., $50 \mathrm{cts}$.

Polygonum Cuspidatum. Knotweed. Large, heart-shaped leaves. Vigorous, growing to $6 \mathrm{ft}$. White flowers in Aug. and Sept. 30 cts.; 2 yr., 50 cts.

Poppy, Oriental (Papaver Orientale). Massive flowers of deep scarlet. May and June. $21 / 2 \mathrm{ft}$. 35 cts.; 2 yr., 50 cts.

Poppy, Oriental: New Named Varieties - $50 \mathrm{cts}$. each. Beauty of Livermore, crimson with dark shadings. Mrs. J. Harkness, bright salmon pink. Mrs. Perry, orange apricot.

Poppy, Iceland (Papaver Nudicaule). Cup-shaped flowers of brilliant colors from white to yellow and

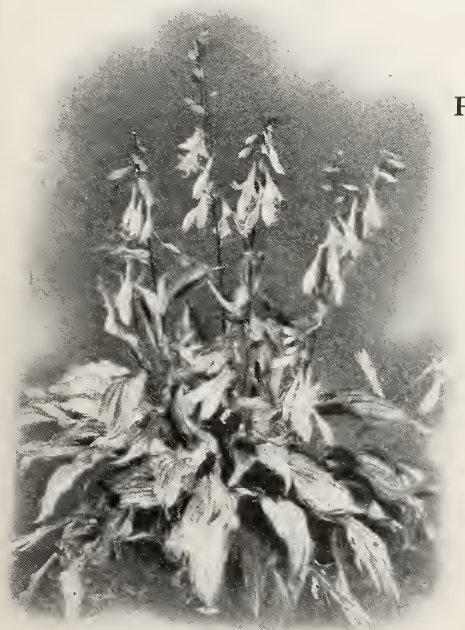

Funkia-Blue Plantain Lily orange scarlet: June to Sept. 12 ins. 30 cts.; 2 yr., $50 \mathrm{cts}$.

Pyrethrum Hybridum. Persian Daisy. Daisy - s h a pe d flowers in white to shades of pink, rose and red. Splendid for cutting. $21 / 2 \mathrm{ft}$. May and June. 30 cts.; 2 yr., 50 cts.

Pyrethrum U 1 iginosum. Giant Daisy. Large white flowers in Aug. and Sept. Splendid for

cutting. 4 to $5 \mathrm{ft} .35 \mathrm{cts}$. 2 yr., 50 cts.

Ranunculus Acris F1. P1. Double Buttercup. Bright yellow flowers in June. 15 ins. 30 cts.; 2 yr., 50 cts.

Rega 1 Lily. The best garden Lily. See Lilium Regale.

R u d beckia Laciniata. G o 1 d e $n$ Glow. The po pular, double yel- Gaillardia-rich red an yellow in color low blossoms of Aug. and Sept. 5 to $6 \mathrm{ft} .30$ cts.; 2 yr., 40 cts.

Rudbeckia Maxima. Giant Cone-flower. Immense yellow flowers. 4 to 5 in. across, on long stems. Gray-green foliage. 5 to $6 \mathrm{ft}$. June to Sept. 35 cts. ; 2 yr., 50 cts

Rudbeckia Newmanii. Single, yellow, daisy-like flowers with high purple cone. Aug. to Oct. $3 \mathrm{ft} .35 \mathrm{cts}$; 2 yr., $50 \mathrm{cts}$

Rudbeckia Purpurea. Purple Coneflower. Rosepurple flowers with tall, brown cone center. 3 to 4 ft. Aug. to Oct. 35 cts.; 2 yr., 50 cts.

Salvia Azurea. Meadow Sage. Azure blue flowers in tall, slender spikes. Aug. and Sept. 3 to $4 \mathrm{ft}$. 35 cts.; 2 yr., 50 cts.

Sedum Acre. Golden Moss. Bright yellow flowers in June and July. Dwarf plant, $t$ ins., useful for rockery or borders. $30 \mathrm{cts}$; 2 yr., $50 \mathrm{cts}$.

Sedum Spectabile. Brilliant Stonecrop. Pink to rosy-red flowers in heavy flat clusters. 18 ins. Aug. and Sept. 30 cts.; 2 yr., 50 cts.

Shasta Daisy. See Chrysanthemum.

Spiraea. See Astilbe and Filipendula

Statice Latifolia. Sea Lavender. Delicate, small, blue flowers cover the branching tops in Aug. and Sept. $2 \mathrm{ft}$. $35 \mathrm{cts}$; 2 yr., $50 \mathrm{cts}$.

Stokesia Cyanea. Cornflower Aster. Blue, Asterlike flowers in July and Aug. 18 ins. 35 cts.; 2 yr., 50 cts.

Trollius. Globe Flower. A glorified Buttercup. Handsome dark green foliage with yellow to orange cup-like flowers in May and June. $2 \mathrm{ft}$. 50 cts.; 2 yr., 75 cts

Valeriana Officinalis. Hardy Garden Heliotrope. Sweetly fragrant, gray-pink flowers in June and July. Deeply cut foliage. $3 \mathrm{ft}$. 35 cts.; 2 yr., 50 cts.

Veronica Longifolia. Japanese Speedwell. Long spikes of attractive blue-riolet flowers. $2 \mathrm{ft}$. Aug. and Sept. 35 cts.; 2 yr., 50 cts.

Veronica Spicata. Speedwell. Spikes of blue flowers in June. $11 / 2$ ft. 35 cts.; 2 yr., 50 cts.

Veronica Spicata Alba. A white form of the above. 35 cts.; 2 yr., $50 \mathrm{cts}$.

Viola. Tufted Pansy. Rich green foliage with blue flowers like small Pansies. 8 ins. May to Sept. Splendid border plant. 30 cts.; 2 yr., 50 cts.

Yucca Filamentosa. Adam's Yeedle. Stiff, sword-shaped leaves with tall spikes of white, drooping flowers in July. $4 \mathrm{ft}$. 50 cts. each; 2 yr., 75 cts. 


\section{SOME HELPFUL PERENNIAL INFORMATION}

\section{Make the Back Yard Bloom}

Plant this border of hardy perennials along the property line and enjoy flowers from May to October. Enough plants here for a bed 35 to 40 feet long of the old garden favorites.

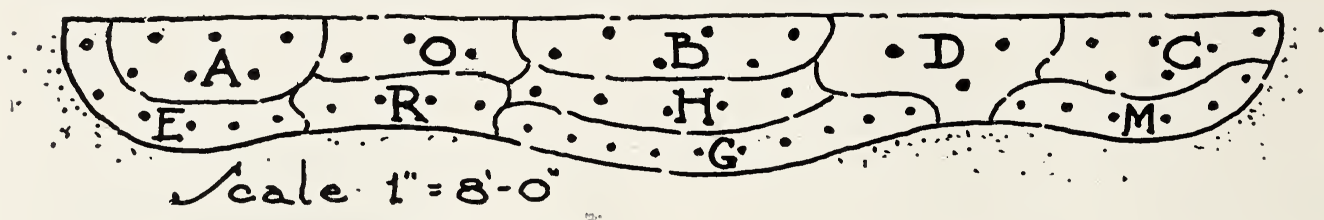

\section{LIST OF PERENNIALS USED}

\begin{tabular}{c|c|l}
\hline Key & No. & \multicolumn{1}{|c}{ Variety } \\
\hline $\mathrm{A}$ & 6 & Delphinium-(Larkspur) 2 varieties. \\
$\mathrm{B}$ & 6 & Pyrethrum-Giant fall Daisy. \\
$\mathrm{C}$ & 6 & Hollyhock-Assorted colors. \\
$\mathrm{D}$ & 3 & Peony-1 pink, 1 red, 1 white. \\
$\mathrm{E}$ & 6 & Gaillardia-Blanket Flower. \\
$\mathrm{G}$ & 10 & 5 Iris ass't, and 5 Persian Daisies. \\
$\mathrm{H}$ & 5 & Hardy Pink Phlox. \\
$\mathrm{M}$ & 6 & Alaska Daisy. \\
$\mathrm{O}$ & 3 & Hardy Aster. \\
$\mathrm{R}$ & 4 & Achillea-Ball of Snow.
\end{tabular}

\section{This Complete Garden 55 Hardy Perennials}

in strong, field-grown stock-selected for a long season of bloom and harmonious colorings-catalogue value, $\$ 19.35$.

SPEGIAL COMBINATION PRICE, (F. O. B.

St. Paul $), \ldots \ldots \ldots 15.00$

\section{Perennials for that Shaded Corner}

In every garden there are some shady spots where it is hard to get the ordinary plants to grow. If there is some sun during part of the day the following perennials should thrive there.

Bleeding Heat (Dicentra)
Balloon Flower (Platycodon)
Columbine (Aquilegia)
Coral Bells (Heuchera)
Globe Flower (Trollius)

Bleeding Heat (Dicentra)

Columbine (Aquilegia)

Coral Bells (Heuchera)

Globe Flower (Trollius)

\section{Lemon Lily (Hemerocallis) \\ Plantain Lily (Funkia caerulea) \\ Lily-of-the-Valley (Convallaria) \\ Monkshood (Aconitum) \\ Violet (Hardy Siberian)}

COLLECTION of SHADE-ENDURING PERENNIALS-2 each of the above kinds-20 plants in all. Price, \$7.00. (F. O. B. St. Paul).

\section{For Cut Flowers}

These 10 perennials are especially suitable for cutting. All have attractive flowers with long stems.

\section{Achillea}

Aster (Hardy)

Coreopsis

Larkspur

Gaillardia

Baby's Breath

Iris (Fleur-de-Lis)

Persian Daisy

Iceland Poppy

Anthemis

\section{Collection of 20 Plants 2 each of the above $\$ 5.50$}

\section{Taller Perennials for the Background}

Plant these in the back row where height is wanted.

Aster Novae-Angliae

Aster Tartaricus

Bocconia cordata

Boltonia

Delphinium

Helenium

Helianthus

Hollyhock

Pyrethrum uliginosum

Rudbeckia laciniata

\section{Collection of 20 Plants 2 each of the above}

\section{Dwarf Perennialsfor Edging and Border}

These low-growing plants are suitable also for rock garden plantings.

Dianthus plumarius

Arabis alpina

Dicentra eximia

Funkia caerulea

Heuchera

Iris pumila

Papaver nudicaule

Phlox subulata

Sedum acre

Viola

\section{Collection of 20 Plants \\ 2 each of the above \\ $\$ 5.50$}




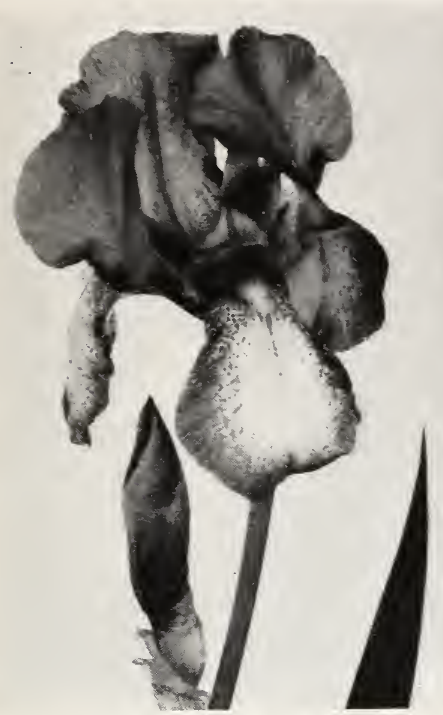

Iris, the "Garden Orchid"

Archeveque. Standards, deep violet 1 purple; falls, rich velvety violet. .... \$ $\$ 1.00$

Aurea. Rich chrome-yellow. Large flower.

Bridesmaid. S., white, shaded silvery lilac; F., white, frilled lilac.

Caprice. S., reddish purple; F., deeper claret. Large and handsome.

Darius. S., yellow; F., lilac.

Eldorado. Bronze, shaded heliotrope; F., violet-purple shaded bronze.

Fairy. Ivory, suffused soft blue

Florentina. White flushed with lavender. Very early.

Her Majesty. S., rose-pink; F., reddish lilac, veined with crimson.

Isolene. S., lilac-pink; F., mauve with golden throat.

Jeanne d'Arc. Lilac and pure white

Johan de Witt. S., bluish-violet; F., deep violet-purple, white veins

King of Iris. S., lemon-yellow; F., maroon, bordered golden yellow. . .

Kochi Atro-Purpurea. (Black Prince.) Purple lilac and velvety-black.

Lent A. Williamson. (New) S., soft violet; F., large, royal purple with golden beard. Highest score variety. 1.50

Lohengrin. Silvery pink - mauve throughout. Large flowers.

Loreley. S., light yellow; F., blue and cream........

Madame Chereau. White, frilled with violet. Very beautiful........

Mithras. S., yellow; F., wine red, yel-

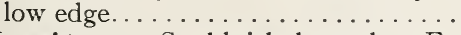

Monsignor. S., bluish lavender; F., velvety purple-crimson with white veinings...............

Mrs. H. Darwin. S., white; F., white with violet at base. . . . . . . . . . .

\section{HARDY IRIS (Fleur-de-Lis)}

Iris is so generally considered as one of the most beautiful of perennial plants as to rightly deserve its common name"The Hardy Garden Orchid." The brilliant flowers, held erect on tall, stiff stems arising from the clump of swordshaped leaves, make the Iris a highly prized flower-garden subject. For cutting use, as house and table decorations, the Fleur-de-Lis is greatly desirable. Stalks of flowers, cut when in bud, often last a week indoors.

PLANTING. Set the roots only deep enough to have them covered with soil and avoid any fresh manure as a fertilizer. Almost any situation with good sunlight and fair soil will prove satisfactory for planting.

PRICES. The 1-year plants are strong, thrifty roots; the 2 -year stock is heavier and will produce results more quickly.

QUANTITY RATE. Ten or more plants of a variety will be supplied at $5 \mathrm{c}$ less per plant. Example: Plants priced at $35 \mathrm{c}$ each are $\$ 3.00$ for ten.

NOTE. In the descriptions "S" or "Standards" refer to the three upright petals. The letter " $F$ " or "Falls" refers to the three drooping or lower petals.

2

Year

$\$ 1.25$
Oriflamme. S., light blue; F., violet Year purple.

Pallida Dalmatica. S., lavender; $F$. clear deep lavender................. .35

Pallida Mandraliscae. Lavenderpurple.

Pallida Speciosa. S., dark lavender shaded light; F., light purple. Clear

color. Tall..................... $.30 \quad .50$

Parisiana. S., lavender pink, mottled; F., creamy white, pink border.

Penelope. S., white; F., white, veined violet.

Quaker Lady. S., smoky lavender;

F., blue and old gold..............
Queen of May. Soft rose-lilac; nearly

F., blue and old gold.............
Queen of May. Soft rose-lilac; nearly pink. Rhein Nixie. S., white; F., rich violet-

1.00 Rhein Nixie. S., white; F., rich violet-

Shakespeare. S., bronze yellow; F., maroon, marked yellow.

.40 Sherwin-Wright. Clear golden yellow.

Spectabilis. Violet blue.

1.00 Veriscolor. Native Flag. Violet blue.

Violacea Grandiflora. S., clear lavender; F., violet blue.

$.25 \quad .40$

$.50 \quad .75$

$.25 \quad .40$

\section{JAPANESE IRIS}

3.00 A large-flowering Iris that blooms in July. Not as hardy as the Germanica type and needs protection. We offer choice plants in WHITE, LIGHT BLUE, VIOLET-BLUE, REDDISH CRIMSON.

Strong roots, 40 cents each; 2-year, 50 cents each.

\section{.40 EARLY DWARF IRIS-For Borders}

Pumila Hybrida. Yellow or purple. $\$ 0.25 \$ \$ 0.40$

\begin{tabular}{l}
.50 Pumila-Schneekuppe. White.... $\quad .40 \quad .60$ \\
\hline
\end{tabular}

\section{SIBERIAN IRIS}

Narrow, grassy foliage; delicate flowers, early July.

Siberian Blue. Violet blue........\$0.25 $\$ 0.40$

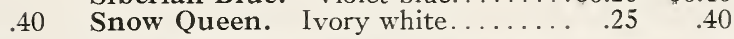

\section{CHOICE HARDY IRIS-A SPEGIAL COLLECTION}

Enough for plenty of beautiful cut flowers every spring. 16 plants -2 each of 8 different standard varieties. Value \$4.40. Special Combination Price (16 plants) \$3.00. Packing Free. Express extra. 


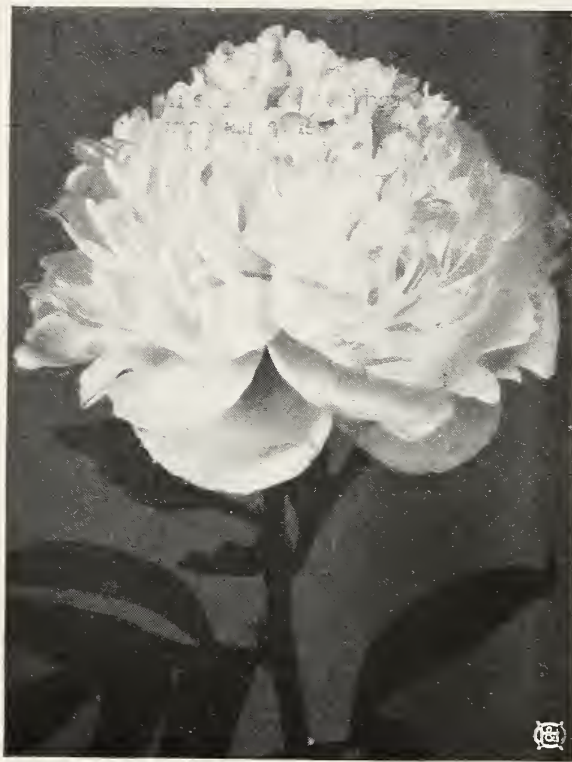

The Peony-rival of the Rose in beauty

\section{PEONIES}

\section{The Flower of the Great Northwest}

A few choice plants of PEONIES will fill your garden with color and fragrance from late May through June. Even the Rose cannot excel in beauty and charm the flowers of the modern Peony. Here, under our northern conditions, it is peer of all flowers in combining so well the qualities of absolute hardiness, great color variation. size, beauty and fragrance of bloom.

Planting. The roots should be set with the "eyes" 2 to 3 inches below the surface and the soil tightly packed about them. Allow a spacing of about 3 feet between the plants.

The soil should be of good substance and the location free of tree roots and dense shade. Bone meal is preferred as a fertilizer. A light covering of straw, after the ground has frozen, is a desirable winter proteztion.

Note. The figures directly following the variety name denote the comparative rating given by votes of the American Peony Society in 1921. The valuation is on a scale of 10 as the perfect score. Any variety given a rating of 7.0 and over can be considered as highly desirable. We list only those sorts suitable to our northern conditions and that have proven their value as producers under ordinary garden culture.

Quality. The "roots" are substantial plants with 3 to 5 strong eyes. The "clumps" vary in size but are the 2 to + year old stock. These older, plants are desirable when immediate flowering results are wanted.

For more complete descriptions see our catalogue, "CREATING YOLR LANDSCAPE"-copy sent on request.

\section{WHITE PEONIES}

Avalanche. 8.7. Ivory white. Very Each Each fragrant. Mid-season..........\$1.00 \$2.50

Baroness Schroeder. 9.0. Light pink tint, opening to pure white. Globe shaped. Late.

Couronne d'Or. 8.1. Snow white with yellow circle of stamens. Large blooms. Late. Excellent cut-flower.

Duchess de Nemours. 8.1. Sulphurwhite free of red markings. Vigorous growth. Early. Fragrant.

Enchanteresse. 8.9. Creamy white scarlet splashings. Late. Fragrant. Strong stem

Festiva Maxima. 9.3. Early and very large. Center flaked crimson. Splendid in every way.

Jeanne d'Arc. 7.9. Crea'n white with pale lilac center. Fragrant Blooms freely.

La Rosiere. 8.3. Large, flat blooms with prominent golden stamens

La Tulipe. 7.5. Delicate lilac-white fading to cream. Late season.

Marie Lemoine. 8.5. Latest blooming white

Mme. Crousse. 7.9. Snow white; center petals carmine edged. Midseason. Large flower

Mons. Dupont. 8.5. Cup shaped flower; glistening white. Center petals have bright crimson markings.
Mme. de Verneville. 7.9. Very full, Roots Clumps heary flower. Blooms early and Each Each freely. Delicate fragrance........\$0.60 \$2.00

Mme. Jules Dessert. 9.t. Creamy white lighted with buff and salmon shades. Golden stamens add further beauty. Large flower; stiff stems. Mid-season.

Primevere. 8.6. The best yellow Peony. Outer petals creamy white, inclosing a central ball of sulphuryellow

\section{PINK PEONIES}

Albert Crousse. 8.6. Delicate flesh pink. Compact flowers with good fragrance

752.50 Claire Dubois. 8.7. Deep riolet-rose tipped silvery white, Largé flower. Late.

Delicatissima. 7.6. Clear pink. Early. .75

Edulis Superba. 7.6. Bright mauve pink. Early.

Elwood Pleas. 8.7. Tiolet Rose, delicate shadings. Fragrant, holds color well.

Eugene Verdier. 8.3. Late. Hydrangea-pink. Large flowers. Fragrant. 2.00

Lady Alexandra Duff. 9.1. Soft delicate pink. Fragrant. Large and very double flowers. Nid-season . . 5.00

Livingstone. 8.1. Large, full; lilacrose, silver tips. Strong grower. 


\section{PINK PEONIES-(Continued)}

Martha Bulloch. 9.1. Shell-pink Roots shading to deep rose-pink in center. Each Enormous flowers. Fragrant. Midseason.................... \$12.00

Mme. Boulanger. 7.8. Glossy, soft pink. Fragrant. Late .......... 1.50

Mme. Calot. 8.1. Flesh with shell pink shadings. Fragrant. Rose type .75

Mme. Camille Bancel. 7.7. Deep pink, lighter center. Globular bloom. 1.00

Mme. Emile Galle. 8.5. Shell pink, shaded heliotrope. Sweetly fragrant. 1.00

Marguerite Gerard. 8.4. Delicate salmon pink, shaded lighter. Midseason.

Mons. Jules Elie. 9.2. Lilac-rose with silver sheen. Very large; fragrant. Early. Bomb type flower... 1.00

Octavie Demay. 8.5. Blush pink. Large.

Phoebe Carey. 8.8. Rose-pink with deeper shades to center. Pleasing fragrance; late blooming. .

Reine Hortense. 8.7. Delicate pink with center flecked crimson. Perfect flowers on tall, stiff stems. Midseason.... .

Richardson's Grandiflora. 8.8. Shell pink. Fragrant. Late. Rose type. . 1.00

Sarah Bernhardt. 9.0. Mauve-rose, silver tipped. Late. Fragrant..

Solange. 9.7. Lilac-white with deep orange salmon tints. Large, full, compact. Exquisite flower....... 7.00

Therese. 9.8. Unexcelled, light pink. 5.00

Tourangelle. 9.4. Flesh white, tinged rose and salmon. Large flower. . . 6.00

Venus. 8.3. Fragrant; delicate pink. 1.50

Walter Faxon. 9.3. Brilliant rose pink, outstanding color. Mid-season. 7.00

\section{RED PEONIES}

Auguste Villaume. 7.3. Violet-rose. Late.

Delachei. 7.1:- Rich crimson-maroon

Felix Grousse. 8.4. Brilliant red. Large globular flower. Fragrant.

Fontenelle. Early, clear brilliant crimson. Good cut flower. Rose type................. 1.00

Grover Cleveland. 8.2. Dark crimson. Large flowers. Vigorous grower 2.00

Karl Rosenfield. 8.8. Rich, glowing crimson. Immense, solid flower. Superb variety. Semi-rose type. . . 1.50

Longfellow. 9.0. Crimson with cherry tones. One of best bright reds.

Lora Dexheimer. 8.4. Early, large. Bright crimson. Stiff stems...... 3.00

Mary Brand. 8.7. Deep red. Midseason. Large flowers. Productive. . 3.00 $\underset{\text { Each }}{\text { Clumps }}$

$\$ 3.00$

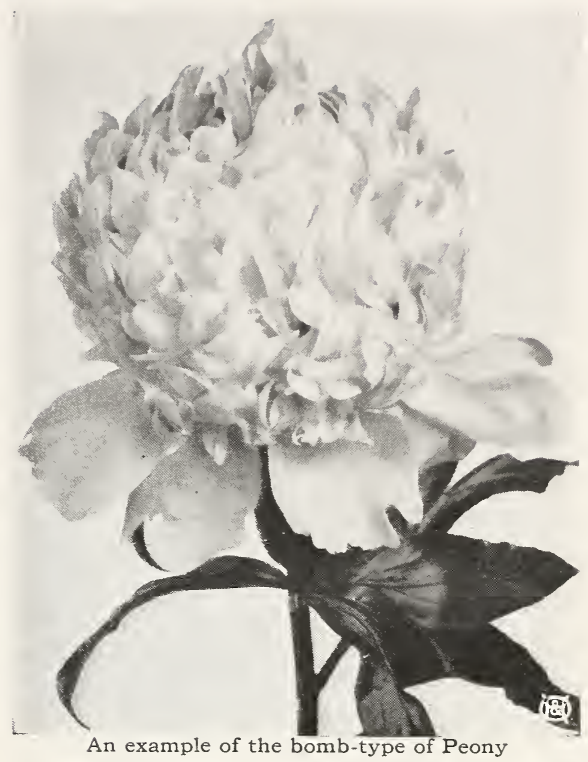

Mme. Bucquet. 7.3. Dark maroon. Each Each Mid-season.

Madame Gaudichau. 8.8. Dark crimson-garnet. Very rare. . . . . \$10.00

M. Martin Cahuzac. 8.8. Darkest red peony.

Officinalis Rubra. Earliest red. Old farorite.

$1.00 \$ 2.00$

Richardson's Rubra Superba. 7.2. Deep carmine crimson. Late blooming. Fragrant

Tenuifolia F1. P1. Early crimson, fern-like foliage. Double flowers... 3.00

\section{SINGLE FLOWERED PEONIES}

The simplicity and delicate structure of the single flowers leads many to prefer them to the heavy, double, showy types. Popular taste is rapidly awakening to the beauty and charm of the single flower.

Albiflora. (The Bride). 8.t. Large white.

Etienne Dessert. China-pink petals with golden stamens. Very large... $\$ .00$

Exquisite. White, center yellow stamens. Mid-season. Japanese type. .10.00

L'Entincelante. 8.1. Clear carmine; silvery margins. Broad petals.... 3.00

Le Jour. 8.2. Pure white, showing yellow stamens and red stigmas.

4.00 Margaret Atwood. Cup-shaped; pure white, gold center. Very rare... . 10.00

Marie Jacquin. 8.3. Delicate flesh white.

Mikado. 8.6. Dark crimson. Like a giant red Poppy. Golden center... $2.00 \quad 4.00$

Tenuifolia. Crimson. Cut-leaf foliage. $1.00 \quad 2.00$

CHOICE PEONIES-A SPECIAL COLLEGTION. Six good roots, all different. Each assortment will have early and late blooming varieties in white, pink and red colors. Value $\$ 4.50$. SPECIAL COMBINATION PRICE (6 plants) \$3.50. 


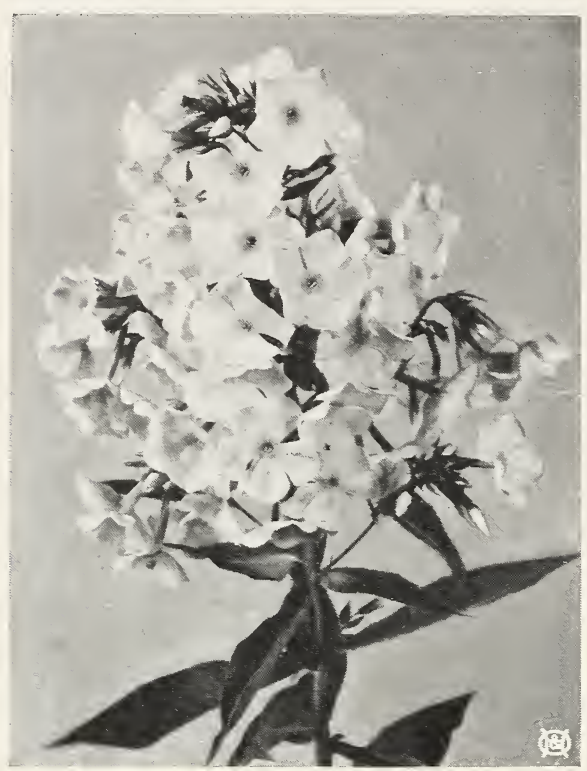

Phlox-the brightest flower of mid-summer

\section{HARDY PHLOX \\ The Most Gorgeous of Late
Summer Flowers}

Phloxes are very hardy floriferous perennials that give bold, brilliant color effects from July to frost. They can be had in pure white, pink, lavender and crimson and in varying combinations of these colors. Filling in, as they do, the period between the late spring and fall blooming plants when the general garden bloom is not abundant, they are practically indispensable to the well-arranged planting.

WHERE TO PLANT. They are exceedingly attractive when planted in masses of a single kind in a bed or border. Their midsummer bloom makes them a most valuable addition to beds where such springblooming plants as Iris, Peonies, Poppies, etc., are located.

CULTURE. Phloxes are gross feeders and react quickly to plenty of rich soil and to abundant watering in dry seasons. The old clumps should be divided and re-planted at least every fourth year.

QUANTITY RATE. Ten or more plants of a variety will be supplied at $5 \mathrm{c}$ less per plant. Example: Plants priced at $35 \mathrm{c}$ each are $\$ 3.00$ for ten.

Mme. Bezanson. Rich crimson, medium height. 40 cts.; 2 yr., 60 cts.

Mrs. Charles Dorr. A beautiful shade of lavender. Very large conical heads. 35 cts.; 2 yr., 50 cts.

Mrs. Jenkins. Immense trusses of pure white flowers. Early. 35 cts.; 2 yr., 50 cts.

Pantheon. Deep salmon-rose; light center. Very large flower. Tall. 35 cts.; 2 yr., 50 cts.

Rheinlander. A most beautiful salmon-pink with deeper center. Immense size. 35 cts.; 2 yr., 50 cts.

Rynstrom. A lovely rose pink, much like Paul Neyron rose. Very large flower heads. 35 cts.; 2 yr., 50 cts.

R. P. Struthers. Rosy carmine with claret-red eye. Very bright; tall. 35 cts.; 2 yr., 50 cts.

Tapis Blanc. The finest of the dwarf white Phlox. Snow-white flowers of large size. Height, 8 to 9 ins. 35 cts.; 2 yr., 50 cts.

Thor. A rich salmon pink with crimson eye. 35 cts.; 2 yr., 50 cts.

W. C. Egan. Soft shade of lilac with bright red eye. General effect is a soft rose color. 35 cts.; 2 yr., 50 cts.

Phlox Subulata. An early spring-flowering type which during the flowering season is a mass of bloom. An excellent plant for the rockery and border, and invaluable for carpeting the ground or covering graves.

Rosea. Pink. 25 cts.; 2 yr., 40 cts.

Alba. White. 25 cts.; 2 yr., 40 cts.

Miss Lingard. The most popular white. Immense heads of white flowers in late June and again in Sept. 35 cts.; 2 yr., 50 cts.

CHOICE HARDY PHLOX-A Special Collection. 12 field-grown roots, 2 each of six standard varieties selected for variations in colors. Value, $\$ 4.20$. Special Combination price (12 plants) $\$ 3.50$. 


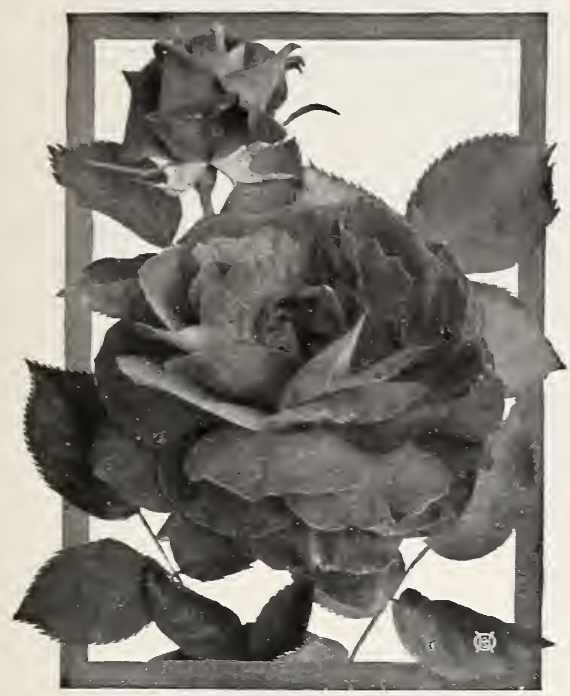

Gruss an Teplitz

\section{HYBRID TEA ROSES}

Monthly or Everblooming

As a group these roses are not as heavy growing nor as hardy as the Hybrid Perpetuals (described on Page 32). Careful winter covering is essential. Their rich coloring, fragrance and long blooming season make them very popular.

To insure maximum results we offer potted $H$. T. Roses-all strong 2 yr. plants that are started and growing when you get them.

Price-\$1.50 each (except where noted). 2 yr., growing, potted plants.

Columbia. Rose pink; delightful fragrance.

Geo. C. Waud. Glowing orange-vermillion.

George Dickson. Deep velvety crimson. Never fades.

Gorgeous. Orange-yellow flushed copper-yellow.

Gruss an Teplitz. Scarlet shading to crimson.

Hoosier Beauty. Large crimson-scarlet.

Jonkheer J. L. Mock. Deep pink.

Kaiserin Augusta Victoria. Creamy-white.

Killarney. Flesh pink. Very fragrant.

Killarney White. Continuous blooming white.

La France. Silvery rose and pink. Large.

Los Angeles (New). Flame touched with coral and gold. Highly fragrant. \$1.75 each.

Miss Lolita Armour (New). Deep coral-red with gold and coppery-red suffusion. \$1.75 each.

Mme. Caroline Testout. Bright satiny rose.

Mme. Edouard Herriot. Coral-red, shaded yellow.

Mrs. Aaron Ward. Distinct Indian yellow.

Mrs. Charles Russell. Rosy-carmine and scarlet.

Ophelia. Flesh color tinted salmon and rose.

Radiance. Brilliant pink.

Red Radiance. Large full flowers of deep red.

Richmond. Rich velvety-crimson. Fragrant.

Rose Marie. Clear rose-pink. Long buds.

\section{ROSES}

\section{The Queen of Flowers}

That the fragrance and beauty of roses can be enjoyed in ur northern gardens is now a proven fact. It is needful, owever, to plant only the hardier sorts and to provide winter otection. Our list contains both old and new varieties that

PLANTING SUGGESTIONS. Make the rose bed in ich soil in a sunny, warm location free of tree roots. Bone eal and well-rotted manure are excellent fertilizers.

WINTER PROTECTION (for all but "Rugosas" and

"Bush Roses"). In late fall heap up the ground around the tops with dry straw and mulch the bed with straw or Climbing Roses should be laid prone, cov-

For more complete descriptions see our book "CREATING OUR LANDSCAPE"'-sent on request.

Soleil D'or. Gold and orange-yellow:

Souvenier de Claudius Pernet (New). Pure sunflower yellow: Holds color. \$2.00 each.

Willowmere. Salmon-pink shaded yellow.

\section{MOSS ROSES}

A much loved, old-fashioned Rose with a delicate mossy covering on the buds.

Price-Strong, 2 -yr., growing pot ted plants, $\$ 1.30$ each.

Blanche Moreau. Pure white; large and full.

Crested Moss. Deep pink; exquisite fragrance.

\section{HARDY RUGOSA ROSES}

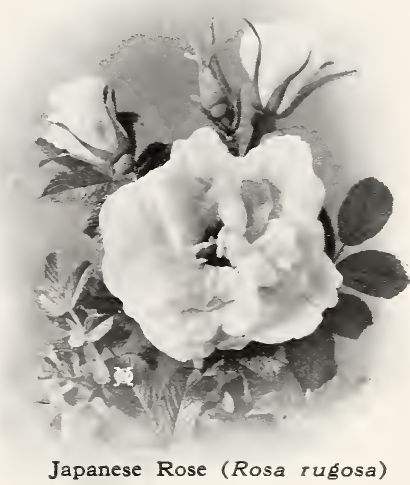

The extreme hardin ess, vigorous growth and dark ornamental foliage of the Rugosas make them highly valued for Northern plantings. Will survive without winter protection. Often used for hedges and in shrubbery beds.

Price (except where noted)-Strong 2-yr. bushes, $\$ 1.25$ each.

Blanc de Coubert. Fragrant, double white.

Conrad Ferdinand Meyer. Silvery rose; fragrant.

F. J. Grootendorst. Continuous bloomer. Bright, crimson roses in clusters.

Hansa. A large, double deep-red rose.

Rugosa Alba. Single, pure white.

Rugosa Rosea. The original type. Pink flowers followed by bright red fruits. $80 \mathrm{cts}$. each; 3 yr. plants, $\$ 1.00$ each. 


\section{CLIMBING ROSES}

Price (except where noted). Strong 2-yr. growing, potted plants, $\$ 1.00$ each.

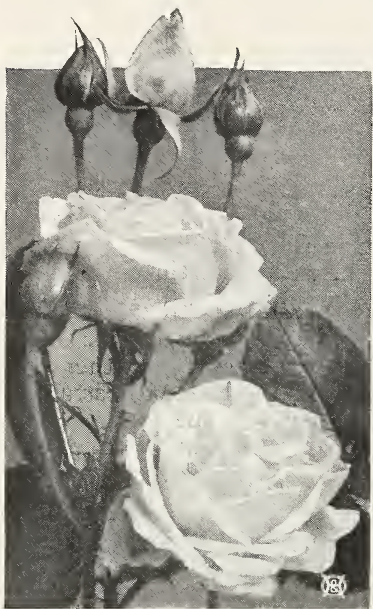

American Pillar. Bright, clear pink; white eye,

ClimbingAmerican Beauty. Rich carmine, $\$ 1.25$ each.

Crimson Rambler. Crimson roses in clusters.

Dorothy Perkins. Clear shell-pink.

Dr. W. Van Fleet. Large flowers of light pink shading deeper at center. Long stems. Fragrant. $\$ 1.25$ each.

Excelsa. Very double intense crimson flowers.

Gardenia. The hardiest yellow climbing rose.

Paul's Scarlet Climber. Large flowers of vividscarlet. Free blooming. \$1.25 each.

Silver Moon. Silvery white. Glossy foliage. $\$ 1.25$ each

Tausendschon. Bright rose softening to pink.

\section{BUSH ROSES}

A hardy class of roses used largely as flowering shrubs in borders, on banks and in naturalistic plantings. Do not need winter protection.

Price (except where noted)-Strong 2-yr. plants, 70 cts. each.

Acicularis. A very hardy type with bright pink flowers followed by red fruits. Red stems.

Lucida. Handsome glossy foliage. Pink flowers. Red fruits. Very hardy.

Rubifolia. Reddish-purple leaves all summer. $\$ 1.00$ each.

Setigera. Prairie Rose. Pink flowers and red fruits.

Wichuraiana. Memorial Rose. Low trailing variety. Bright foliage and white flowers.

Harrison's Yellow. Clear golden yellow. \$1.25 each.

Persian Yellow. Deep yellow. Double. \$1.25 each.

\section{BABY RAMBLER ROSES}

These Polyantha roses bloom in clusters continuously through the summer. 'Their dwarf, compact habit suits them to border planting. A highly desirable type for the home yard.

Price-Strong 2-yr. growing, potted plants, $\$ 1.50$ each.

Baby Rambler. Clusters of crimson Roses over a long season.

Baby Tausendschon. Flesh-pink flowers.

Erna Teschen dorff. Vivid crimson flowers that hold their color well.

Ellen Poulsen. Deep pink flowers. Vigorous.

\section{HYBRID PERPETUAL ROSES}

The Hardiest Type of Large-Flowering Garden Roses

To insure maximum results we offer potted $\mathrm{H}$. $\mathrm{P}$. Roses-all strong 2 yr. plants that are started and growing when you get them. Results are certain.

Price-\$1.50 each, growing, potted plants.

Anna de Diesbach. Brilliant crimson; very double. Baron de Bonstetten. Rich dark red; fragrant. Captain Christy. Shell-pink, shading dark in center.

Capt. Hayward. Crimson-carmine; large perfect form.

Clio. Flesh-color, shaded rosy pink center.

Frau Karl Druschki. Silvery white; large.

General Jacqueminot. Brilliant crimson.

George Arends. Large, rose-pink.

J. B. Clark. Intense scarlet.

Hugh Dickson. Crimson, scarlet-shaded.

Madame Gabrielle Luizet. A magnificent pink.

Magna Charta. Bright pink, suffused carmine.

Margaret Dickson. Pure white; fine form.

Marshall P. Wilder. Cherry-carmine; fragrant.

Mrs. John Laing. Soft, delicate pink.

Paul Neyron. A beautiful deep rose; the largest. Prince Camille de Rohan. A velvety crimson.

Ulrich Brunner. Brilliant cherry-crimson.

\section{SWEETBRIAR ROSES}

Rubiginosa. The well-known Sweetbriar with aromatic foliage and sweetly fragrant pink flowers.

Price 2-yr. growing, potted plants, $\$ 1.30$ each.

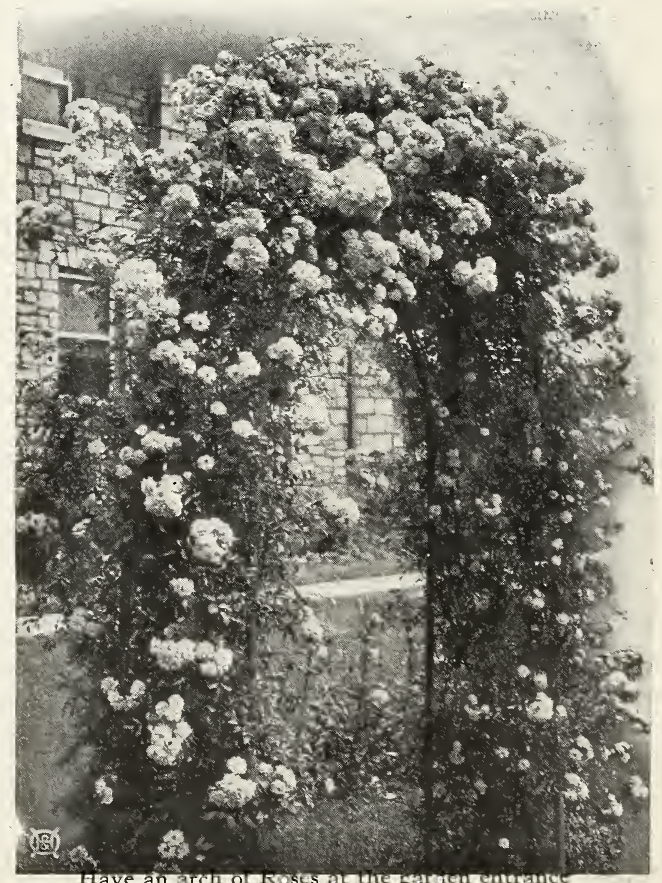




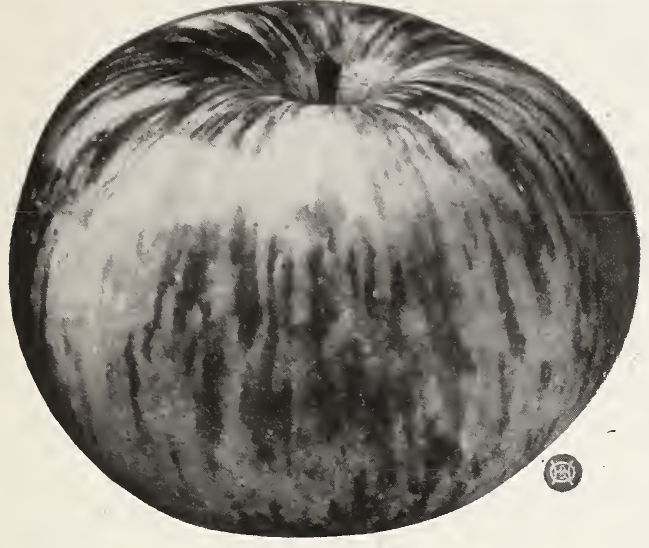

HARDY APPLES

The Peer of all Hardy Tree Fruits.

A spacing of about $25 \mathrm{ft}$. between trees is considered best.

Prices. 4 to $5 \mathrm{ft}$., 2-yr. stock. 5 to $6 \mathrm{ft}$., 3-yr. stock. Each 10 $\$ 1.00 \$ 9.00$ $\begin{array}{ll}1.25 & 11.00\end{array}$ 6 to $7 \mathrm{ft}$., 3 and 4 -yr. stock. $1.50 \quad \mathbf{1 4 . 0 0}$

Extra large sizes can be furnished in most of the varieties at $\$ 2.00$ to $\$ 10.00$ each.

Anisim. Very hardy, medium-size red apple. Duchess. Yellow with red stripes. Very hardy. Hibernal. Large fruit. Extremely hardy.

Malinda. Rich yellow with dull blush. Long keeper. Northwestern Greening. Pale green. Good quality: Okabena. An early fall apple. Excellent eating.

Patten's Greening. Desirable for eating or cooking. Peerless. Minnesota origin. Fair size yellowish fruit. Wealthy. Hardy, abundant bearer. Red fruit.

Yellow Transparent. Early. Hardy. Good eating

\section{HARDY CRAB APPLES}

In addition to their food value the "Crabs" have highly ornamental qualities of blossom and fruit.

Prices. 4 to $5 \mathrm{ft}$., 2-yr. stock. .... \$1.00 $\$ 9.00$ 5 to $6 \mathrm{ft} ., 3$-yr. stock ..... $1.25 \quad 11.00$ 6 to $7 \mathrm{ft} ., 3$ and 4 -yr. stock. $1.50 \quad 14.00$

Extra large sizes, in some varieties, at $\$ 2.00$ to $\$ 7.50$ each.

Early Strawberry. Early. Medium size, red striped. Hyslop. Good size, dark crimson fruit. Late.

Minnesota. Extremely hardy. Large. Yellow and green fruit. Bears liberally.

Siberian. Small ornamental red fruit. Best for jellies and preserving.

Transcendent. Yellow blushed with carmine. Very juicy. Acid flavor.

Whitney. Large red fruit. Early. Good eating.

\section{HARDY PLUMS}

Plums are especially adapted to home-yard plantings as the trees are of moderate size and can be planted 16 to $18 \mathrm{ft}$. apart. When in blossom they are highly ornamental, while the abundant fruit is a choice culinary and table delicacy.

\section{DELICIOUS FRUITS}

\section{For Home-Yard Planting}

The planting of fruit trees and berry bushes in the home yard is a practical and worth-while investment. The fruit trees not only give desirable shade, but further repay the planter for their modest cost by their beautiful masses of spring flowers and their yields of fruit.

The berry bushes and grapes take up so little space that every yard can easily accommodate enough plants to supply practically all the luscious fresh fruit that is wanted. Years of experience in growing fruit in Minnesota permits us to recommend the following varieties as reliable and sturdy sorts for our Northern conditions. We welcome your inquiries as to fruit culture and care.

For more complete variety description see our book, "CREATING YOUR LANDSCAPE." Sent on request.

\section{HARDY PLUMS (Cont.)}

Prices. Except where noted

4 to $5 \mathrm{ft}$., 2-yr. stock.

5 to $6 \mathrm{ft}, 2$ and $3-y r$ stock.

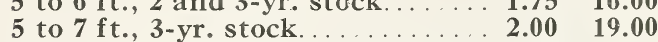

Extra large sizes, in some varieties, at $\$ 3.00$ to $\$ 7.50$ each.

De Sota. Very hardy. Sweet, juicy orangecolored fruit. 5 to $6 \mathrm{ft}$., $\$ 1.50 ; 6$ to $7 \mathrm{ft}$., $\$ 1.75$.

Hansen Hybrids. New varieties developed by Prof. N. E. Hansen of South Dakota. Large fruited and improvements over the native types. Hanska. Bright red fruit of apricot flavor.

Opata. Heavy bearer. Purple fruit. Pleasing flavor.

Sapa. Early ripening, dark purple plum. Bears heavily even when trees are young.

Waneta. Very large red fruit. Sweet. Hardy.

Loring Prize. Large, bright red. Juicy, sweet and mildly acid. Ripens early.

Monitor. Minn. origin. (New). Large, dark red. Vigorous growing. Firm, sweet flesh. Late.

Surprise. Large, bright red. Very hardy. 5 to 6 ft., $\$ 1.50$.

Tonka. Minn. origin. (New). Very hardy, dependable and productive. Red fruit; semi-freestone. Mid-season.

Underwood. Minn. origin. (New). Early ripening. Red fruit, small pit; free-stone. Very hardy:

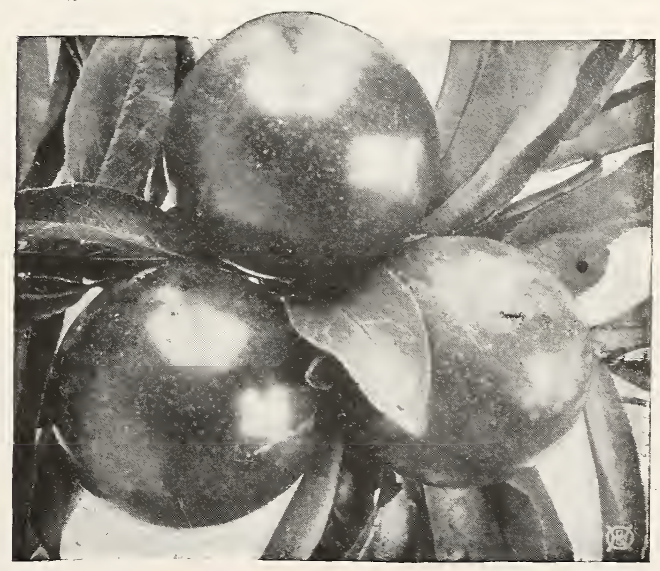

Plums-a choice, easy-to-grow fruit 


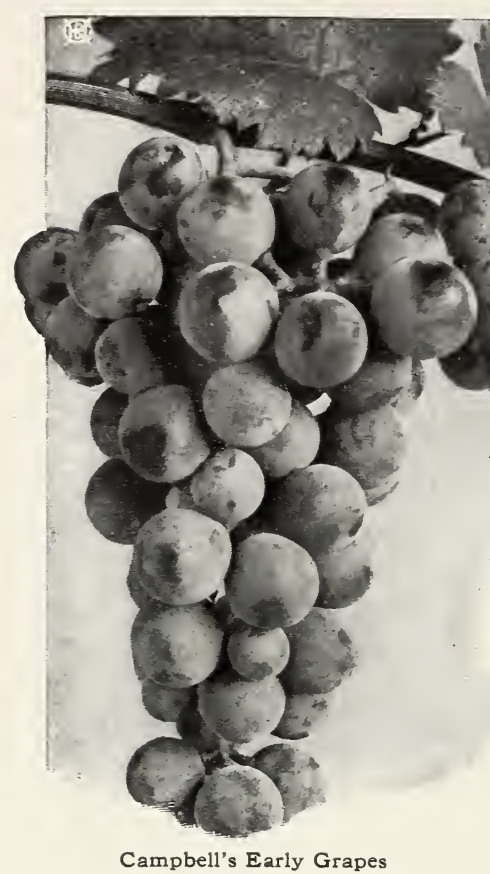

Campbell's Early Grapes

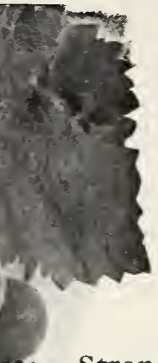

rices: Strong 2-yr. roots, 60 cts.; 3-yr. roots, 80 cts.

Alpha. A native variety remarkable for its good size and flavor. Healthy and vigorous vine. Exceedingly hardy.

Beta. Minn. origin. Very hardy. Large. The best for cooking and grape juice. Has the hardiness and sprightly flavor of the wild grape.

\section{RED GRAPES}

Prices: Strong 2-yr. roots, 60 cts.; 3-yr. roots, 80 cts.

Agawam. Early ripening, dark red berry. Good size.

Concord. The large, popular black grape.

Campbell's Early. An early fruiting black grape.

Hungarian. Semi-wild origin with berries slightly larger than Beta. Hardy without covering.

Moore's Early. A good homegarden variety.

Worden. Early ripening. Berries large and sweet.

\section{CHERRIES}

The Morellos or "Pie Cherries" are the only true cherries hardy for Minnesota. These are not recommended for plantings North or West of the Twin Cities.

Prices. Except where noted:

$\begin{array}{rc}\text { Each } & 10 \\ \$ 1.50 & \$ 14.00\end{array}$

4 to $5 \mathrm{ft}$., 2-yr. stock.

5 to $6 \mathrm{ft}$., 3-yr. stock.

2.0018 .00

Early Richmond. Early variety with dark red fruit English Morello. Large tender fruit, very dark.

Wragg. Similar to English Morello but hardier.

Homer. Minn. origin. Dark red, good sized fruit.

Zumbra. Cross between Sweet Cherry and native Sand-Cherry. Fruit large; dark red; small pit. Very close to a sour cherry. Good for dessert or for preserving. Quite hardy.

4 to $5 \mathrm{ft} ., \$ 1.75 ; 5$ to $6 \mathrm{ft}$., $\$ 2.00$.

\section{CHERRY PLUM HYBRIDS}

Compass. Bright red fruit with distinct cherry flavor. Very hardy. Bears abundantly. Fine for cooking or canning. Price. 4 to $5 \mathrm{ft}$., \$1.25; 5 to $6 \mathrm{ft}$., $\$ 1.50$.

\section{GURRANTS}

A highly profitable and productive fruit. Plant about four feet apart. (Cannot be shipped west of Minnesota because of Federal quarantine laws).

Prices. Except where noted:

Strong 2-yr. plants.....40 cts.; $\$ 3.50$ per 10 Strong 3 -yr. plants.....66 cts.; 5.00 per 10 Black Naples. Black fruit of large size.

Cherry. Large bright red berries; rather acid.

Fay's Prolific. Abundance of large red berries.

Long Bunch Holland. Late fruiting red variety.

Perfection. (New). A very large red berry in heavy clusters. Price. 2-yr., 50 cts.; 3-yr., 70 cts.

White Grape. A large, white sweet currant.

\section{WHITE GRAPES}

Prices: 2-yr. roots, 60 cts.; 3 -yr. roots, 80 cts. Moore's Diamond. Healthy and vigorous; prolific bearer.

Niagara. Very popular early ripening sweet grape. White Pocklington. Pale green with tinge of yellow. Bunch and berries are large.

\section{RASPBERRIES}

The Raspberries are very easy to grow and are practically certain to produce abundant crops every season. A row can easily be included in the home garden or can be planted along the side or rear property lines. Space $3 \mathrm{ft}$. apart, with $5 \mathrm{ft}$. between rows.

\section{RED AND PURPLE RASPBERRIES}

Prices (except where noted): 20 cts. each; $\$ 1.50$ for ten.

Columbian. A purple berry of firm texture. Good flavor. Bush does not spread.

King. An early-ripening, large size bright-red berry. Hardy and productive.

Latham (Minn. No. 4). A vigorous hardy bush with heavy yields of large delicious, red fruit. (Our plants are Mosaic free).

St. Regis. Ripens early and continues to bear until October. Good size, bright red berries.

\section{BLACK RASPBERRIES}

(Not as hardy as the Red varieties. Need winter protection).

Prices: 20 cts. each; $\$ \mathbf{1 . 5 0}$ for ten.

older. A low-branching bush considered the hardiest of the blackcaps. Fruit juicy and sweet. 


\section{STRAWBERRIES}

The favorite small fruit. The Strawberry grows so easily and yields so abundantly that anyone can grow enough fresh berries for the table in a small patch in the yard. Space the plants $1 \mathrm{ft}$. apart in the rows with rows at $3 \mathrm{ft}$. intervals. Apply a winter mulch of straw after the ground freezes in the fall.

\section{JUNE-BEARING STRAWBERRIES}

Prices. Strong plants, 40 cts. per doz.; $\$ 2.75$ per 100.

Senator Dunlap. The best known and most planted variety. Does well everywhere. Large crops of big, deep-red berries. Early fruiting.

\section{EVERBEARING STRAWBERRIES}

Fresh strawberries from middle summer until frost. Keep the blossoms picked off until July 15.

Progressive. Vigorous growing and productive. Good size berries of fine flavor and appearance. Plants set this spring give a good crop this summer. We are convinced that this is the best of the Everbearing varieties.

Prices. Strong plants, 60 cts. per doz. $\$ 4.50$ per 100 .

\section{GOOSEBERRIES}

A very hardy and vigorous growing bush fruit. Space, 3 to $4 \mathrm{ft}$. apart in fertile soil.

(Cannot be shipped west of Minnesota because of Federal quarantine laws).

Prices. Strong 2 -yr. plants, 40 cts.; $\$ 3.50$ for 10 Strong 3-yr. plants, 60 cts.; 5.00 for 10 Downing. A large oval pale green berry.

Houghton. A pale red, sweet berry.

Josselyn. Large, smooth red berry. Mildew free. Pearl. Light green. Heary producer.

\section{BLACKBERRIES}

Need winter protection. Canes should be bent over and covered with earth. Space $31 / 2 \mathrm{ft}$. apart.

Prices. $20 \mathrm{cts}$. each; $\$ 1.50$ for ten.

Eldorado. Large jet-black berries in clusters. Sweet flavor.

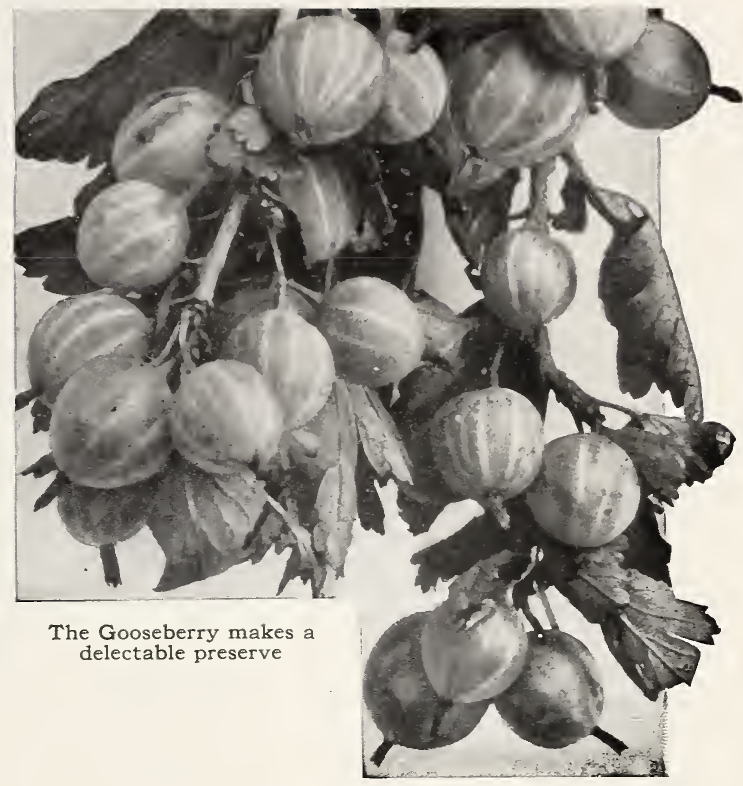

\section{ASPARAGUS}

Easy to grow and will last indefinitely. Set the plants with the crowns 2 inches below the surface. Allow 15 inches between plants.

Prices. Strong roots, 75 cts. doz.; $\$ 4.00$ per 100.

Argenteuil. A choice light colored variety of very vigorous growth and extra heavy size. Fairly free from rust. Originated in France and highly favored here.

Washington Rust Proof. An excellent green asparagus. Always favored for table use.

\section{RHUBARB OR PIE-PLANT}

A choice early-spring delicacy for sauces and pies. Strong roots, $25 \mathrm{cts}$. each; $\$ 2.50$ per dozen.

\section{HORSE RADISH}

A few roots will supply all the fresh relish needed. Strong roots, $20 \mathrm{cts}$. each; $\$ 2.00$ per dozen.

\section{GARDEN BOOKS OF SPEGIAL VALUE}

These books are intensely practical and we recommend them as a reference library of interesting and instructive horticultural information. We supply them at the publisher's prices.

GARDEN GUIDE. This book tells how to plan, plant, and maintain the home grounds; how to grow good regetables and fruit; to how raise beautif ul flowers; how to take care of porch plants, lawns, windowboxes. 250 pages, profusely illustrated. Cover in four colors. Price, postpaid, paper, S1.10; cloth cover, S1.65.

MILADY'S HOUSE PLANTS. By F. E. Palmer, a recognized authority. Any woman, with the aid of this book, may have a fine collection of plants to add cheer and beauty to the home during the fall and winter months, then in spring and summer to lend their beauty to the outdoor planting. Profusely illustrated with 100 instructive pictures. Cover in four colors. Price, postpaid, paper, 80 cents; cloth cover, $\mathrm{S} 1.10$

HOME FRUIT-GROWER. By Prof. M. G. Kains. A clear, simple, practical and comprehensive volume for the amateur who seeks to grow high-quality fruits for home needs. Each fruit suitable to the home garden is discussed. Copiously illustrated. 212 pages. Price, postpaid, paper, S1.10; cloth cover, S1.65.

PRACTICAL LANDSCAPE GARDENING. By Robert Cridland. Written by a practical landscape architect who tells in simple texts, with profuse illustrations, how to plan, plant, and develop the home yard. Working plans and photographs of finished results are given. The result of twenty years' experience. 266 pages, handsome cover in four colors. Price, postpaid, S2.65.

THE LITTLE BOOK OF PERENNIALS. By Prof. A. C. Hottes. Deroted to the principles of growing, using and propagating the hardy perennial flowers. Discusses over 125 species with most of them illustrated. Price, postpaid, paper, S1.10; cloth, cover \$1.65. 


\section{THE LAWN}

A soft carpet of grass over the yard-it's luxuriant green, restful and inviting - is the most sought after of all landscape embellishments. Even the most modest home has great charm and beauty when surrounded by a trim, neat lawn. Good lawns are the logical result of sowing good grass seed on fertile, prepared soil and bestowing a reasonable amount of after-care and consideration on its upkeep.

Soil Preparation must be thorough. Plow or spade, grade and lastly pulverize the surface. Any fertilizer used should be worked well into the ground.

Seeding. The best quality seed costs only a few cents more per pound than unreliable, cheap mixtures. Use the best obtainable and realize the most from your work and planting. Sow one pound to every 200 sq. feet of area. Sow evenly, rake lightly and water thoroughly.

Watering, when required, should be sufficient to soak the soil. Light, surface sprinklings are harmful.

Our book, "The Principles of Lawn Making," will be sent, without charge, on request.

\section{LAWN GRASS SEED}

(Note. Add 8c per pound to prices listed on all grass seed wanted by Parcel Post.)

\section{VELVET-SOD MIXTURE}

A very high grade mixture of those hardy grasses that will combine to make a beautiful and lasting lawn. Especially prepared to withstand our Northern climatic conditions. Its weight, over 20 pounds per bushel, clearly indicates its purity and freeness from chaff and adulteration. We use this mixture on all our landscape contracts and recommend it highly.

Lb., 65 cts.; 5 lbs., $\$ 3.00 ; 10$ lbs., $\$ 5.75 ; 20$ 1bs., $\$ 11.00$

\section{CAPITAL CITY MIXTURE}

A combination of good quality grass seeds that is admirably adapted to general lawn uses. It contains some White Clove and will produce a close sward in a short time.

Lb., 60 cts.; 5 lbs., $\$ 2.75 ; 10$ lbs., $\$ 5.25 ; 20$ lbs., $\$ 10.00$

\section{SHADY-SIDE MIXTURE}

By using this seed it is possible to get a growth of lawn under trees and in shady places where the ordinary grasses will not grow. Has always proven satisfactory for such positions

Lb., 70 cts.; 5 lbs., $\$ 3.25 ; 10$ lbs., $\$ 6.25 ; 20$ lbs., $\$ 12.00$

\section{TERRACE MIXTURE}

A special mixture of spreading, deep-rooting grasses that will thrive and hold the soil on terraces and slopes. It is very resistant to drought and poor soils and gives results where the ordinary grasses fail.

Lb., 60 cts.; 5 lbs., $\$ 2.75 ; 10$ lbs., $\$ 5.25 ; 20$ lbs., $\$ 10.00$

\section{WHITE CLOVER}

The best Clover for lawn uses because of its small leaves and dense close growth. It is often sown on new lawns for its protection to the tender grasses the first year. Admired by many for its fragrant, dainty flowers.

$1 / 2$ lb., 40 cts.; 1 1b., 75 cts.; 5 lbs., $\$ 3.50 ; 10$ lbs., $\$ 6.75$

\section{KENTUCKY BLUE GRASS}

A beautiful grass that should be the main constituent of every good lawn here in the North. Sometimes used alone, but becomes better established if sown in mixtures. Our seed is choice grade carefully re-cleaned of the high average weight of $21 \mathrm{lbs}$. per bu.

Lb., 70 cts.; 5 lbs., \$3.25; 10 lbs., \$6.25; 20 lbs., $\$ 12.00$

\section{LAWN AND GARDEN FERTILIZERS}

Old lawns often become spotted in appearance-the - grass losing its fresh green color and drying out in patches. This condition indicates that a plant food is needed, that the grass roots are starving. An application of our prepared fertilizer-inexpensive, free of weed seeds and easy to handle-will give the lawn new life. It is a good practice to broadcast a fertilizer dressing over the lawn each spring and so keep the grass healthy and vigorous. Always wet down the grass with the hose after spreading the plant food.

SPECIAL LAWN FERTILIZER. A mixture of the best plant foods that will revive the grass growth and add nourishment. Sow evenly using 25 pounds per 1,000 square

10 lbs., $\$ 1.00 \quad 50$ lbs., $\$ 2.25 \quad 100$ lbs., $\$ 4.00$

BONE MEAL. A splendid fertilizer for Roses, Peonies, flower or shrub beds. High phosphate content. Frequently used on the lawn (30 pounds to 1,000 square feet).

10 lbs., $\$ \mathbf{1 . 0 0} \quad \mathbf{5 0}$ lbs., $\$ 2.25 \quad \mathbf{1 0 0}$ lbs., $\$ 4.00$

HARDWOOD ASHES. Valued as a lawn fertilizer because of its high potash content. Use 40 pounds per 1,000 square feet.

10 ibs., 75 cts.

50 1bs., $\$ 1.75$

100 lbs., $\$ 3.00$
SHEEP MANURE (Pulverized). A quick acting plant food for general use about the lawn, flower beds or garden. For lawns use 30 pounds per 1,000 square feet and wet down. This is a pure, natural manure rich in nitrogen and potash and free of weed seeds or litter.

10 lbs., 75 cts. $\quad 50$ lbs., $\$ 1.75 \quad 100$ lbs., $\$ 3.00$

NITRATE OF SODA. The cheapest form in which to apply nitrogen stimulant to plants encouraging quick, green growth. Not a general plant food. For lawns sow 8 pounds to 1,000 square feet and wet down.

10 lbs., $\$ 1.25 \quad 50$ lbs. $\$ 4.50$

100 lbs., $\$ 8.00$ 


\section{HOLM \& OLSON \\ (INCORPORATED)}

Nurserymen and Landscape Architects

20-24 W. 5th Street 


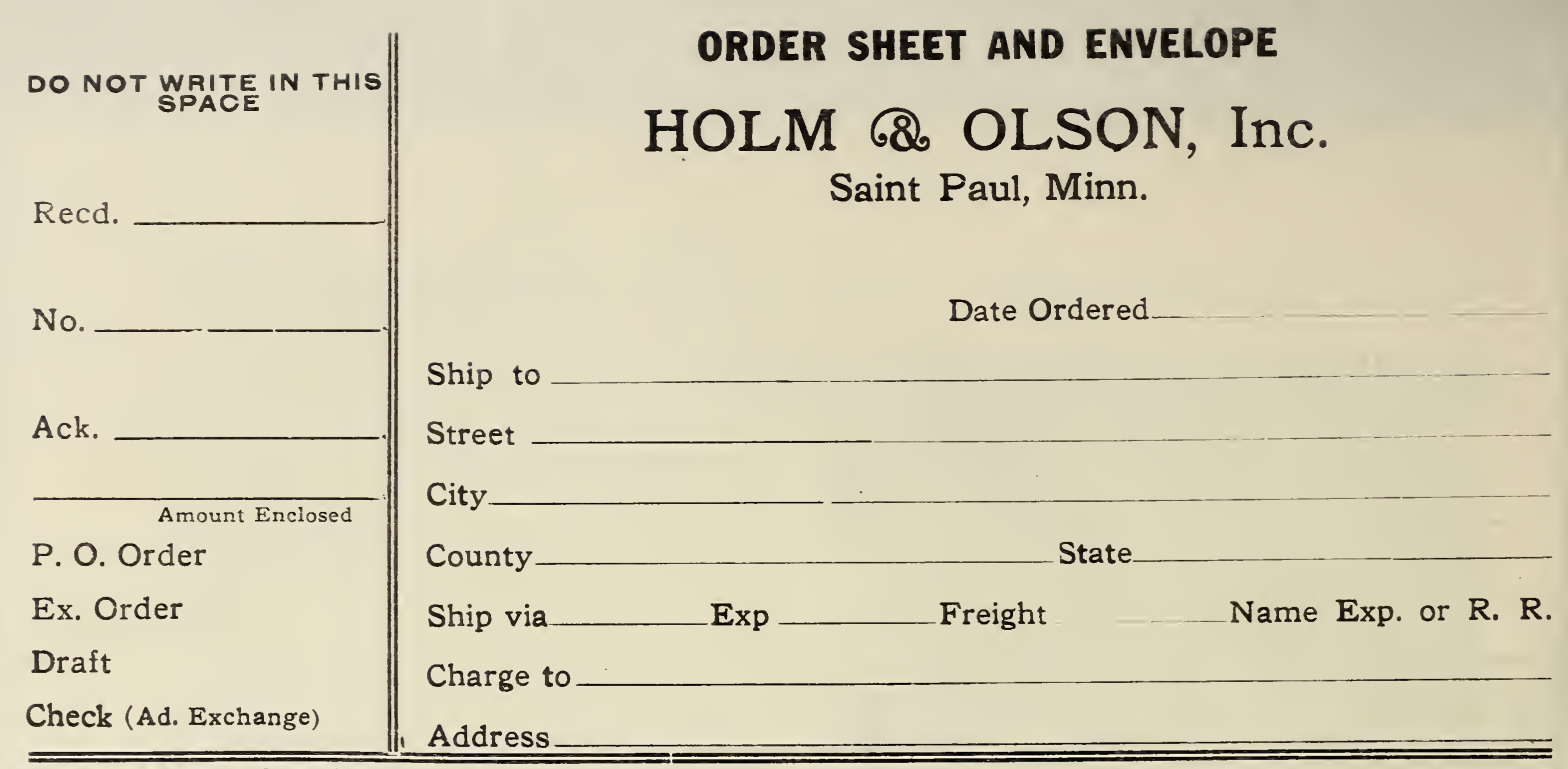

\section{TERMS CASH}

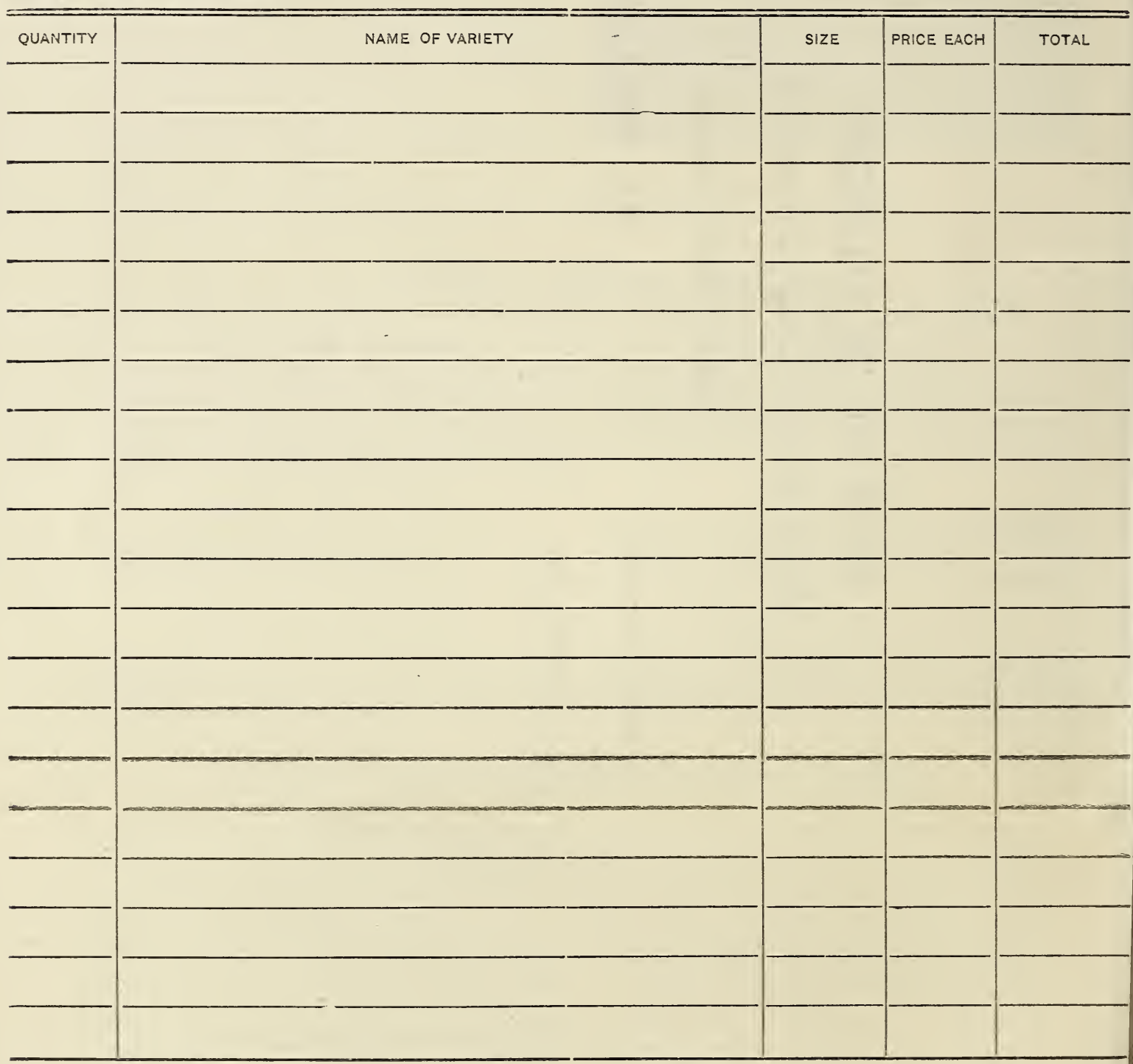

Names of those requiring Landscape Service: 








\section{INDEX OF PLANT VARIETIES}

This Index shows all items listed in our 1926 catalogue; both the common and botanical names of trees, plants, and shrubs are given, which will help you to locate varieties and descriptions.

Page

Abies............6, 7

Acer............. 4

Achillea............21

Aconitum..........21

Adam's Needle.......22

Aesculus............ 4

Alaska Daisy........21

Almond, Flowering.....

Althea.................24

Amelanchier.........12

Amorpha............ 9

Ampelopsis..........19

Amygdalus.

Anchusa.

Anthemis.

Apples. .

Aquilegia.

Arabis. .

Aralia.

Arborvitae.

Aristolochia........19

Armeria...........21

Aronia...............10

Arrow-wood..........16

Artemisia...........21

Ash................... 35

Asters...........21, 22

Astilbe............22

Baby's Breath.......23

Baptisia............22

Basswood..........4 4

Beard Tongue........25

Berberis..........10, 18

Betula.............. 3

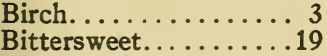

Blackberries. ........ 35

Blanket Flower......23

Bleeding-Heart. . . . . 22

Bocconia...........22

Boltonia ............22

Books...............35

Boston Ivy............19

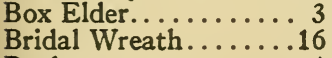

Buckeye........... 4

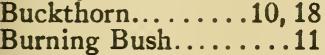

Buttercup...........25

Butternut.......... 3

Campanula.........22

Canterbury Bell......22

Caragana............14

Catalpa............. 3

Cedar.............. 7

Celastrus............19

Celtis.............. 4

Centaurea..........22

Cherries..............3

Cherry, Indian........10

Chokeberry...........10

Chrysanthemum.....22

Cinquefoil............14

Clematis.........19, 22

Clethra..............10

Columbine.........21

Coneflower, Purple....25

Coral Berry..........10

Coreopsis.
Page

Cornflower........22 How to Prune a Hedge. 18

Cornus...........10, 11 How to Prune Shrubs. .17

Cotoneaster.......10, 18 Hydrangea.........12

Crab, Flowering...... 3 Indigo, False.

Cranberry, High-Bush.16

Cress, Rock...........21

Cup-and-Saucer......22

Currant, Flowering....10

Currant, Mountain....10

Currants.............34

Cydonia............14

Daisy, Alaska.......21

Daisy, Michaelmas....21

Daisy, Moonpenny...22

Daisy, Giant.......25

Daisy, Persian. ......25

Day Lily...........22

Delphinium.......22

Dianthus...........22, 23

Dictamnus.........23

Dicentra Exima......23

Digitalis...........23

Dogwood..........10, 11

Dragonhead, False...25

Dutchman's Pipe......19

Echinops..........23

Elaeagnus. . ..........14

Elder.............11

Elm.............. 4

Euonymus..........11

Evergreens.........6 6

Ferns............23

Fertilizers...........36

Filapendula.......23

Fir.................

Flax.............24

Forsythia.............11

Foxglove..........23

Fraxinus.............

Fringe, Purple............

Gaillardia..........23

Gas Plant..........23

Ginkgo............ 4

Golden Bell.

Golden Glow..........23

Golden Moss........25

Golden Tuft..........21

Gooseberries..........35

Grapes...........19, 34

Grape, Wild. ........19

Gypsophila..........23

Hackberry.......... 4

Harebell...........22

Hawthorn........... 16

Hedges............18

Helenium . . . . . . . . 23

Helianthus..........23

Heliopsis...........23

Heliotrope..........25

Hemerocallis.........24

Hercules' Club... . . . . . 9 9

Heuchera..........24

Hibiscus . . . . . . . . . 24

Hollyhocks. ........24

Honeysuckle....12, 18, 19

Horse-Chestnut. ...... 4

Horse-Radish.
Iris.................27

Ivy............... 19

Jerusalem Cross......24

uneberry.

uniperus.

arkspur..........22

Lawn Grass Seed......36

Liatris.

Lilac.

Lilium.

ily...

12,13

.24

Linum.

Locust, Black...........

Locust, Flowering. ....13

Lonicera .......12, 18, 19

Loosestrife.........24

Lupinus.............24

Lychnis...........24

Lycium..........13, 19

Lythrum.

Maidenhair Tree.

Mallow...

Malus.

Maple.

Marguerite

Matrimony Vine . . .13, 19

Meadowsweet.........24

Mentha............24

Milfoil..............21

Mint ...........24

Mist Tree.............

Mock Orange.....13,14

Monkshood..........21

Morus............ 5

Mountain Ash

Mulberry.

Myosotis..............25

Oak.

Oenothera.

Olive, Russian

Ornamental Tres.

Pachysandra.......25

Papaver............25

Pea Tree.............. 14

Pentstemon .........25

Peonies...........28, 29

Pepper Bush.........10

Perennials, Hardy....21

Phalaris.............25

Philadelphus......13,14

Phlox................ 30

Physalis............25

Physostegia........25

Picea ............. 8

Pie-Plant..............

Pink..............22, 23

Pinus............. 7

Platycodon..........25

.25
Uuniper.

Lantern Plant, Chinese.25

Lavender, Sea .......25

inden

Oswego Tea.........24
Page

Plum, Flowering....5, 14

Plum, Purple.......5, 14

Plums................ 33

Polygonum.........25

Poplar........... 5

Poppy..............25

Potentilla..........14

Prunus Triloba....... 5

Purple Fringe........11

Pyrethrum.........25

Quercus............. 5

Quince, Japanese......14

Ranunculus........25

Raspberries..........34

Regal Lily...........25

Ramnus........10,18

Rhubarb.............35

Rhus..........11, 16

Ribbon Grass........25

Ribes..............10

Robinia..........4, 13

Rosa Rugosa.........14

Rose...........31, 32

Rudbeckia.........25

Russian Olive......14, 18

Salix..............5 5

Salvia...............25

Sambucus...........11

Sedum............25

Shasta Daisy........25

Sheepberry:..........16

Shrubs............ 9

Siberian Pea Tree.....14

Snowball............16

Snowberry...........14

Sorbus.............. 5

Spearmint..........24

Speed well . .......25

Spiraea.....15, 16, 18, 25

Spruce............ 8

Statice............25

Stokesia...........25

Stonecrop..........25

Strawberries.........35

Strawberry Bush......11

Sumac.............16

Sunflower.............23

Sweet William.......22

Symphoricarpos....10, 14

Syringa.........12, 13

Tamarix............16

Taxus............ 8

Thorn Apple........16

Thuja.............6 6

Trilia................

Ulmus........... 4

Valeriana...........25

Vegetable Roots.......35

Veronica...........25

Viburnum..........16

Vines and Creepers...19

Viola.............25

Virginia Creeper....... 19

Walnut, Black....... 5

Wayfaring Tree......16

Weigela............16

Willow............ 5

Wisteria............ 19

Yew............. 8

Yucca...............25 

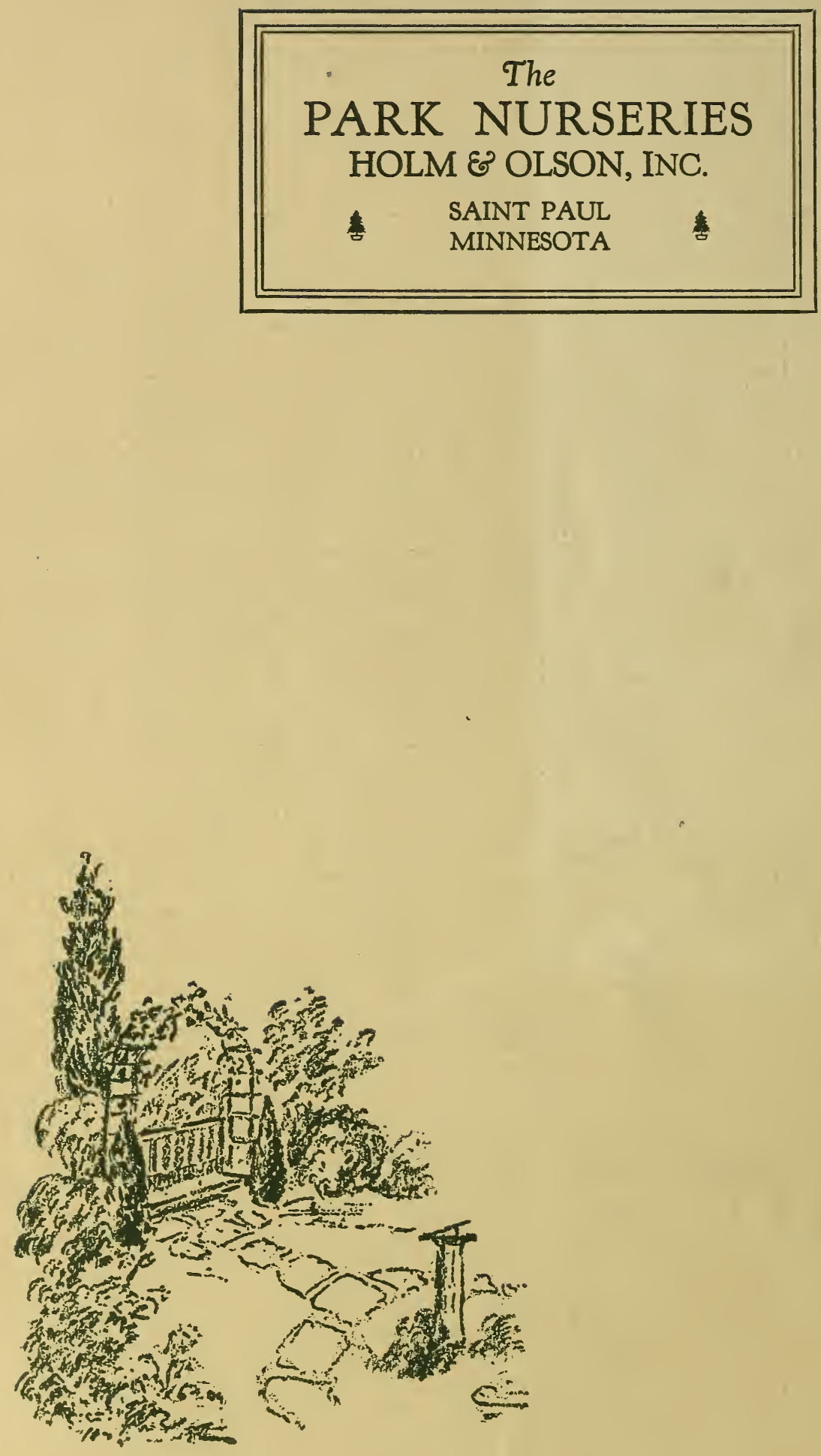